\title{
대중문화예술인 자살문제 대응정책 연구
}

채지영 



\section{대중문화예술인 자살문제 대응정책 연구}

A Study on the Policy to Respond to the Suicide Problem of Korean Pop Culture Artists

채지영 

연구책임

채지영 한국문화관광연구원 연구위원

공동연구

윤유경 공군사관학교 교수 

대중문화예술인 자살문제 대응정책 연구

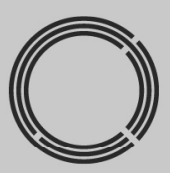

연구개요 



\section{1. 서론}

\section{가. 연구 배경 및 목적}

1) 연구 배경

- 대한민국의 높은 자살률

- OECD 주요 국가 자살률 순위에서 한국은 2010년 1위를 차지한 이래 줄곧 1 2위에 머물고 있음

- 대중문화예술인 자살의 베르테르 효과

- 대중문화예술인의 자살은 유명인과 자신을 동일시하여 모방자살을 증가시키는 '베르테르'의 효과가 있어 사회적 영향에 대한 특별한 주의가 필요함

- 특히 10 20대가 유명인의 모방 자살 경향이 높기 때문에 사회적 관심과 적극적 대응이 요구됨

- 대중문화예술인은 한류의 주역이자 가장 중요한 자원

- 한류의 주역이자 핵심인 대중문화예술인들의 노동환경은 매우 취약한 실정이며, 성장지향형 산업 시스템 내 종사자 안정망은 부실한 상황임

- 대중문화예술인들은 스트레스 대처 방안 미숙과 사회적 인지도로 인하여 심리 적·정신과적 치료에 소극적일 수밖에 없고, 대중문화산업과 기업이 아직까지 영세한 상황에서는 국가가 연예인을 포함한 대중문화산업 종사자에 대해 심리 적 안전망 지원에 보다 적극적일 필요가 있음

- 정책적 지원에 대한 타당성 확보 및 정책 실효성 제고 필요

- 연예인 자살에 대한 적극적인 정책적 개입에 대한 타당성을 확보하고 보다 실효 성 있는 정책 방안 모색이 필요함

\section{2) 연구 목적}

- 대중문화예술인 자살 현황 분석 및 파급효과 검토

- 대중문화예술인 자살 방지에 대한 정책적 개입 필요성 및 타당성 확보

- 대중문화예술인 자살예방을 위한 실효성 있는 정책 방안 제안 


\section{나. 연구 범위 및 방법}

- 연구범위

- 2000년 이후 현재까지 국내 및 해외(자살관련 국가정책을 실행하는 나라)

- 대중문화예술인의 자살 현황과 영향력, 자살방지프로그램 사례분석 및 정책 제 안을 포함함

- 연구 방법

- 문헌연구, 대중문화예술인, 문화산업종자사, 정신건강 전문가 심층 인터뷰 및 자문회의

\section{2. 대중문화예술인 자살문제 현황}

- 대중문화예술인의 특성

- 대중문화예술인의 자살 문제를 이해하기 위해서는 대중문화예술인의 직업적 환 경과 심리적 특성에 대한 이해가 전제되어야 할 것임

- 대중문화예술인은 감정노동에 종사하는 노동자로서 현실과 연기·무대에서의 편 차가 큰 불안정한 감정상태가 유발될 수 있으며, 정상적으로 누릴 수 없는 사생 활, 인터넷 악플, 폐쇄적 인간관계 등의 사회적 환경으로 인해 자살의 전조가 되는 스트레스 및 우울증이 증가될 수 있음

- 또한 어린 나이 때부터 연예계에 입문한 경우 정상적인 학교생활이 어려워 일반 적인 사회적 발달과업(developmental tasks)을 수행하기 어려움

- 대한민국 자살 현황

- 세계 최고의 자살률: 2010 년에 OECD 주요 국가 자살률 1 위를 차지한 이래 현재까지 줄곧 1 2위를 유지하고 있음

- 남성의 자살이 여성보다 2.5 배 많고, 70,80 대 노년층 자살이 심각한 사회문제 로 대두되고 있으며, 청소년의 경우 자살이 암이나 교통사고를 제치고 사망원인 1 위를 차지하고 있음 
- 대중문화예술인 자살 현황

- 대중문화예술인 직업군에 대한 별도의 공식적인 자살 통계는 없으나, 2008년 연예인 최진실 자살부터 2019년 설리, 구하라 자살까지 유명 연예인들의 자살 은 커다란 사회적 이슈가 되고 있음

- 대중문화예술인 자살의 사회적 영향력: 베르테르 효과

- 유명 연예인들의 자살 뒤에는 이를 모방하는 베르테르 효과가 나타는데, 이는 자살자 수 증가뿐 아니라 자살 방법에도 영향을 미침

- 미디어 보도의 영향

- 유명인 자살에 대한 미디어 보도는 자살을 자극하는 방아쇠 촉발기능이 있으며, 오랫동안 노출되는 자살관련 기사는 미디어의 단순노출효과(mere exposure effect)와 정당화, 면역효과, 축적효과 등이 있어 자살을 일반적인 현상 및 문제 해결방법으로 인식시킬 수 있음

- 특히 미디어 보도는 청소년들에게 더 큰 영향을 미칠 수 있으므로 주의해야 함

\section{3. 자살예방 정책 현황}

- 자살예방 관련 기관

- 보건복지부: 자살예방정책 주무 부처로 자살예방종합대책 및 기본계획을 수립. 추진하고 있으며, 2018년에는 자살예방과를 신설하여 운영하고 있음

- 자살예방정책위원회: 국무총리식 소속이며, 2021년부터 중앙부처의 자살예방 추진실적을 평가할 예정임

- 한국자살예방협회: 보건복지부 소관 비영리단체로 자살예방교육과 홍보활동, 자살예방 프로그램 개발 및 연구, 정책 제안 등의 활동을 수행하고 있음

- 중앙자살예방센터: 보건복지부가 국가 차원의 자살예방사업 추진을 위해 설립 한 기관으로, 자살통계 및 데이터 제공, 자살예방백서 발간, 프로그램 인증, 생 명지킴이 교육, 지역자치단체 자살예방 사업 평가 및 컨설팅 등 다양한 자살예 방 실무 사업을 수행하고 있음 
- 중앙심리부검센터: 자살 사망자의 사망원인을 다각도로 분석하고 자살 유족을 지원하는 역할을 수행함

- 광역 및 기초 자살예방센터/정신건강복지센터: 지역사회 내 자살예방사업을 기 획·수립·조정·수행하는 기관

- 한국예술인복지재단: 대중문화예술인을 포함, 예술인의 복지에 대한 체계적이 고 종합적인 지원을 하는 기관으로, 지원 사업으로 심리상담 및 자살예방교육이 포함되어 있음

- 대중문화예술인지원센터: 한국콘텐츠진흥원 내에 개설된 센터로, 대중문화예술 인들의 법률적 지원과 권익보호를 위한 프로그램 운영, 직업능력 개발 및 교육 지원 등을 수행하고 있으며, 지원 사업 내에 심리상담 및 자살예방 교육 프로그 램 등이 포함되어 있음

- 자살예방 사업을 수행하는 다수의 기관이 존재하고 있으나, 대중문화예술인에 특화되어 이들의 직업적 환경이나 심리적 특성을 고려한 자살예방 교육은 아직 까지 매우 불충분한 상황임

- 특히, 대중문화예술인을 지원하고 있는 두 개 기관에서도 연예활동을 하는 대중 문화예술인들이 실질적으로 지원을 받을 수 있는 프로그램은 없으며, 연습생 역 시 비용과 횟수가 제한되어 있어 실효성 있는 지원은 이루어지지 않는 상황임 - 더욱이 기관의 전문성 부족은 향후 대중문화예술인 자살예방 및 정신건강 문제 를 효과적으로 예방하고 대응하는데 한계가 있음

- 자살예방 정책

- 국가의 자살예방 정책은 ‘자살은 예방이 가능한 것’이라는 전제 하에 자살예방 교육 프로그램을 개발하고 이를 통해 '자살예방 생명지킴이'를 교육·양성하는데 초점을 맞추고 있음

- '자살예방 생명지킴이' 교육을 시행한 각 기관에서는 자살 사고가 대폭 감 소하는 등 실질적인 효과성을 높이 평가받고 있음

- 자살예방 홍보정책으로 2018년 자살보도 권고기준 3.0을 제작·발표하였으며, 영상콘텐츠 가이드라인도 제작·배포하였음

- 그러나 자살보도 권고기준은 말 그대로 '권고기준' 으로서 강제 이행이 어려우며, 
최근 인터넷, $\mathrm{SNS}$ 등의 발달로 인해 보도 전반에 걸친 모니터링과 권고기준 준 수 요구가 어려운 상황임

- 해외 자살예방 정책

- 핀란드는 1990년대, 일본은 2000년대 초, 우리보다 앞서 최악의 자살률을 경험 한 국가이나, 국가적으로 자살예방에 대한 연구, 정책 조직 확립, 다양한 자살예 방 사업 전개, 적극적인 예산 투입 등으로 자살률을 획기적으로 낮추는 데 성공 하여 국제적인 자살예방 정책 모범 시례로 인정받고 있음

\section{4. 전문가 의견조사}

- 조사 개요

- 대중문화산업계 현장 전문가 및 대중문화예술인, 콘텐츠 관련 공공기관, 자살예 방 관련 학계 및 기관 전문가 등 총 17 명을 대상으로 대중문화예술인의 심리적 특성, 대중문화예술산업계에서의 자살 대응 정책 필요성과 자살예방 교육 방향 등에 대한 심층 인터뷰를 실시함

- 조사 결과

- 대중문화예술인은 특수한 직업 환경으로 인하여 심리적인 불안과 스트레스가 매우 높으며, 인간관계가 매우 배타적이고 제한적이기 쉬워 정신건강에 문제가 생겼을 때 사회적 지지를 받기 어려운 환경임. 연습생은 청소년 시기에 산업계 에 진입하여 정서적으로나 사회적으로 성숙될 수 있는 교육이 부족할 수 있음

- 자살예방 교육에 대한 문화산업계 현장의 니즈는 지원기관의 우려와는 달리 높 은 것으로 나타남

- 교육 대상은 연예인보다는 연습생과 기획사 직원에 초점을 맞추어야 하며, 직원 의 경우 자살예방교육은 업무능력 향상에도 도움을 줄 수 있을 것으로 판단됨

- 전문가들은 대중문화연예인이 한류 등 국가와 사회에 기여한 바에 비해 노동환 경 개선에 대한 지원이 매우 미약했음을 지적하였고, 업무 특수성에 기반하여 정신건강에 대한 지원이 집중적으로 이루어져야 함을 제안하였음 
- 자살예방을 위해서는 대중문화예술인에게 특화된 교육 프로그램 개발이 선행되 어야 하며, 현장에서 실효성 있는 교육이 실행되기 위해서는 대중문화기획사 직 원에 대한 '의무교육' 지정을 제안하였음

- 문화체육관광부 장관과 대형 기획사 대표, 유명 연예인들이 솔선수범하여 자살 예방교육을 수행하였을 때, 교육의 효과 및 홍보 효과가 높아질 것으로 보임

- 향후 자살예방 교육은 근원적인 문제해결을 위하여 그 범위와 대상을 넓혀 대중 문화예술인 및 문화산업 종사자의 마음건강 정책으로 확대할 것을 제안함

\section{5. 정책 제안}

- 대중문화예술인 자살예방 대응 정책의 필요성

- 대중문화예술인 자살은 문화산업 및 국가이미지에 미치는 부정적인 영향, 일반 인 모방 자살을 촉진시키는 '베르테르' 효과, 대중문화예술인들의 직업동 환경 등을 고려해볼 때 대중문화예술인의 자살예방에 대한 국가 정책의 필요성이 큼

- 대중문화예술인 자살예방 대응정책

- 대중문화예술인 개인 취약성 지원을 위한 심리상담 강화

- 대중문화예술인 자살예방 저변확대를 위한 게이트키퍼 양성

- 대중문화예술인 환경 개선 및 자살예방 교육 의무화, 미디어 보도 모니터링

- 대중문화예술인 자살예방 대응 콘트롤 타워로 “콘텐츠 마음건강 센터” 건립 


\section{목차}

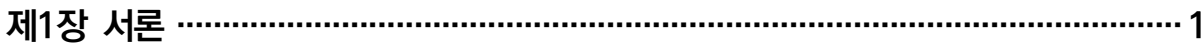

제1절 연구 배경 및 목적 3

1. 연구 배경 및 목적 3

2. 연구 범위 및 방법 5

제2장 대중문화예술인 자살문제 현황 ……………………………………………7

제1절 대중문화예술인 및 산업의 특성 9

1. 대중문화예술인 심리적·직업적 특성 9

2. 대중문화예술산업의 구조적 특성 12

제2절 대중문화예술인 자살 현황 15

1. 대한민국 자살 현황 15

2. 대중문화예술인 자살 현황 17

3. 대중문화예술인 자살의 베르테르 효과 19

제3절 소결 $\quad 22$

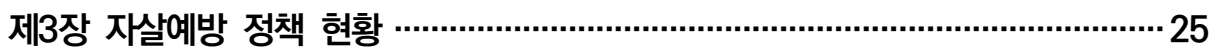

제1절 자살예방 관련 기관 $\quad 27$

1. 보건복지부 27

2. 자살예방정책위원회 30

3. 한국자살예방협회 31

4. 중앙자살예방센터 31

5. 중앙심리부검센터 33

6. 광역 및 기초 자살예방센터/정신건강복지센터 33

7. 한국예술인복지재단 34

8. 대중문화예술인지원센터 35

9. 시사점 38 
제2절 자살예방을 위한 교육 및 사업 40

1. 자살예방 교육 40

2. 자살예방 홍보 사업 44

3. 시사점 51

제3절 해외 자살예방 정책 사례 52

1. 일본의 자살예방 대책 52

2. 핀란드의 자살예방 대책 54

3. 해외 자살예방 정책의 시사점 56

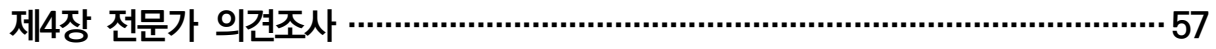

제1절 조사 개요 59

제2절 조사 결과 $\quad 61$

1. 정신의학 전문가(자살관련 기관, 정신과의사, 상담심리학자 등) 61

2. 문화산업 전문가(기획사 종사자, 콘텐츠 관련 기관 근무자 등) 65

3. 시사점 70

제5장 정책 제안 ………….............................................................................. 71

제1절 대중문화예술인 자살문제 대응정책의 필요성 73

1. 대중문화예술인 자살 취약성 및 영향 74

2. 대중문화예술인 자살문제 대응을 위한 저변 확대 필요 75

3. 대중문화예술인 노동환경 개선 필요 75

제2절 대중문화예술인 자살문제 대응정책 76

1. 대중문화예술인 개인 취약성 지원 방안 76

2. 대중문화예술인 자살예방을 위한 저변 확대 77

3. 대중문화예술인 자살예방을 위한 관련 환경 개선 79

4. 대중문화예술인 자살예방 대응 콘트롤 타워 건립 80

\section{참고문헌 / 85}

ABSTRACT / 87 


\section{표 목차}

〈표 1-1〉 심층인터뷰 대상자 6

〈표 2-1〉 연예인과 일반 직장인의 특성 비교 11

〈표 2-2〉 대중문화예술인 자살 현황 18

〈표 2-3〉 유명 연예인 자살 이후 2달간 자살자 수 및 자살 증가효과 추정치 20

〈표 3-1〉 보건복지부 자살예방정책과 주요 업무 28

〈표 3-2〉 자살예방 기본계획 및 국가행동계획 29

〈표 3-3〉 중앙자살예방센터 설치의 법적 근거 32

〈표 3-4〉 정신건강복지센터의 역할 34

〈표 3-5〉 대중문화예술인지원센터 설립 및 예술인 지원과 관련된 법적 근거 36

〈표 3-6〉 대중문화예술기획업자 교육 프로그램 개요 37

〈표 3-7〉 대중문화예술기획업자 교육 프로그램 개요 37

〈표 3-8〉 대중문화예술인지원센터 심리상담 이용자 수 38

〈표 3-9〉 국가인증 게이트키퍼 교육 프로그램(보고듣고말하기, 이어줌인) 구성 43

〈표 3-10〉 자살보도 권고기준 3.0의 전문 46

〈표 3-11〉 자살보도 권고기준 3.0의 5가지 원칙 46

〈표 3-12〉 자살예방 및 생명존중문화 조성을 위한 법률 47

〈표 3-13〉미국의 자살보도 권고기준 48 


\section{그림 목차}

[그림 2-1] OECD 주요국가 20년간 자살률 추이

[그림 2-2] OECD 주요국가 20년간 자살률 추이1987 2018년 성별에 따른 자살률 추이 16

[그림 2-3] 응급실에 온 자살 시도 환자 수(인구 1만 명당 명) 20

[그림 2-4] 2008년 유명 배우 사망 사건 발행 전후 목맴 자살 사망자 수 연간 추이 21

[그림 3-1] 보건복지부 및 관련 기관의 자살예방사업 협력체계 30

[그림 3-2] 자살예방센터의 신규 자살예방 프로그램 인증과정 33

[그림 3-3] 영상콘텐츠 자살 장면 가이드라인 4원칙 50

[그림 3-4] 일본의 자살자 수 추이 52

[그림 3-5] 핀란드의 인구 10만 명당 자살사망률 54

[그림 5-1] 대중문화예술인 자살 원인과 해결 방안 73

[그림 5-2] 2019년 국무총리 및 정부서울청사 직원 대상 자살예방 생명지킴이 교육 79

[그림 5-3] (가칭) '콘텐츠 마음건강 센터' 구성 83 
대중문화예술인 자살문제 대응정책 연구

\section{제1장}

서론 



\section{제1절 연구 배경 및 목적}

\section{1. 연구 배경 및 목적}

\section{가. 연구 배경}

- 한류의 핵심 자원인 대중문화예술인에 대한 보호과 지원 부족

- 드라마·K-pop 등 한류를 이끌고 있는 콘텐츠의 주역은 대중문화예술인들로, 이들의 스타성과 활동이 콘텐츠산업 경쟁력의 핵심이 되고 있음

- 하지만, 성인이 되기 전부터 학업과 일상생활을 희생해가면서 연예산업계에 뛰 어 들었던 다수의 연예인들은 과도한 스트레스에 대한 대처 방안 학습이 부족한 경우가 많으며, 사회적인 인지도 때문에 심리적·정신적 문제가 발생해도 치료 에 소극적인 경향이 높음

- 특히 어린 나이부터 학교생활에서 떨어져 과도한 연습과 훈련에 몰입하는 기획 사 시스템은 이들에 대한 충분한 보호와 지원을 갖추고 있지 않은 경우가 많아 노동환경의 사각지대로 남아있음

- 그럼에도 불구하고 산업의 영세성과 국가적 관심 부족으로 인하여, 대중문화예 술인들의 노동환경 개선 및 종사자 안전망 구축에 대한 지원정책은 매우 미약한 상황임

- 대중문화예술인의 자살 문제는 산업 발전의 어두운 이면

- 대중문화예술인들의 자살은 급격히 발전하는 문화산업의 어두운 이면으로, 성 장지향형 산업 시스템 내 종사자의 안정장치가 부실하고, 산업 발전에 비해 여 전히 대중문화예술인의 노동환경은 취약함을 보여주는 시례임

- 또한, 대중문화예술인의 자살 사건은 우리 청소년들뿐 아니라 전 세계 청소년과 한류 팬들에게 부정적 영향을 미치고, 한류 및 우리 문화산업 시스템에 대한 비 
판을 증가시키며 한류 발전을 저해할 우려가 있음

- 대한민국의 높은 자살률

- 한국은 $\mathrm{OECD}$ 주요 국가 자살률 순위에서 2010년 1위를 차지한 이래 줄곧 1 2위를 차지하면서 '자살'이 사회적 이슈로 부각되고 있음

- 사망원인으로서 자살(고의적 자해)은 1992년에 10위였으나, 2000년에 8위로 상승하였고, 2007년에는 4위 까지 올랐으며, 2017년 이후에는 암, 심장질환, 폐렴, 뇌혈관질환에 이은 5 위를 차지하고 있음

- 특히 생산가능 연령대의 인구집단에서는 자살이 사망원인의 1 위(10대, 20 대, 30 대)이며, 40 대와 50 대에서는 2 위를 차지하고 있음(보건복지부, 중앙자살예 방센터, 2020)

- 연예인 자살의 베르테르 효과

- 높아지는 한국의 자살률 가운데 유명 연예인들의 자살도 이어져, 2000년대 이 은주, 정다빈, 안재환, 최진실, 종현(샤이니) 등에 이어 2019년도에도 설리, 구 하라 등 유명 아이돌 출신 연예인이 자살하면서 사회적인 큰 충격을 주고 있음

- 연예인의 자살은 ‘베르테르’ 효과, 즉 유명인과 자신을 동일시하여 모방자살을 증가시키는 효과가 있어, 사회적 영향력에 대한 특별한 주의가 필요함

- 특히 10 20대의 젊은 층은 유명인의 자살을 모방하는 경향이 높다는 연구결과 들이 있어, 연예인의 자살에 대한 사회적 관심과 적극적인 대응의 필요성이 제 기되고 있음

- 정책적 지원에 대한 타당성 확보 및 정책 실효성 제고 필요

- 연예인들의 환경적 특성과 그들의 자살이 문화산업과 사회 전반에 미치는 파급 력을 고려할 때, 연예인 자살에 대한 적극적인 정책적 개입의 필요성이 커지고 있음

- 하지만, 정부가 대중문화예술인이라는 특정 직업군에 대해 지원 정책을 강화하 기 위해서는 보다 공고한 타당성이 확보되어야 할 것임

- 이와 더불어, 국가 정책 실행에 있어 보다 실효성 있는 정책 방안이 모색되어야 할 것임 


\section{나. 연구 목적}

- 연예인 자살 현황 분석 및 연예인 자살의 파급효과 검토

- 연예인 자살 방지에 대한 정책적 개입 필요성 및 타당성 확보

- 실효성 있는 연예인 자살 방지 정책 방안 제안

\section{2. 연구 범위 및 방법}

\section{가. 연구 범위}

- 공간적 범위

- 국내 및 해외(자살 관련 국가 정책을 실행하는 나라 포함)

- 시간적 범위

- 2000년 이후 현재

- 내용적 범위

- 대중문화예술인 자살 현황 및 영향력 분석

- 국내외 자살 방지 프로그램 시례 분석

- 대중문화예술인 자살 방지 정책 제안

※「대중문화예술산업발전법」에 따른 대중문화예술인은 '대중문화예술용역을 제공하는 자 또는 대중문화예술용역을 제공할 의사를 가지고 대중문화예술사업자와 대중문화 예술용역과 관련된 계약을 맺은 자'로 규정되어 있으나, 본 연구 대상으로는 그 폭을 좁혀서 대중문화기획사(1인 기획사 포함)에 소속되어 대중문화예술활동을 하는 연예 인과 기획사 소속 연습생을 주 대상으로 검토하였음

\section{나. 연구 방법}

- 문헌연구

- 자살 현황과 관련한 통계자료 분석

- 대중문화예술인 자살의 영향력에 관한 문헌연구 
- 대중문화예술인들의 심리적 특성 및 산업 구조적 특성에 관한 문헌연구

- 자문회의 및 심층인터뷰

- 대중문화예술인, 대중문화예술산업 종사자, 자살예방 관련 종사자, 상담 및 정 신의학 관련 학자 및 전문가 대상 $1: 1$ 심층 인터뷰

- 인터뷰 대상자(예정자) 총 20명 내외

〈표 1-1〉 심층인터뷰 대상자

\begin{tabular}{c|l}
\hline 그룹 & \multicolumn{1}{c}{ 대상 } \\
\hline 공공기관 & $\begin{array}{l}\text { - 중앙자살예방센터 담당자 } \\
\text { - 대중문화예술지원센터 담당자 }\end{array}$ \\
\hline \multirow{2}{*}{ 상담 및 정신과 전문가 } & $\begin{array}{l}\text { - 한국자살예방협회 담당자 } \\
\text { - 상담 전공 교수 및 연구자 } \\
\text { - 정신과 의사 등 }\end{array}$ \\
\hline 엔터테인먼트 산업계 & $\begin{array}{l}\text { - 대중문화 예술인 } \\
\text { - 대중문화산업 관련 기획사 종사자 등 }\end{array}$ \\
\hline
\end{tabular}


대중문화예술인 자살문제 대응정책 연구

제2장

대중문화예술인

자살문제 현황 



\section{제1절 대중문화예술인 및 산업의 특성}

대중문화예술인이 자살률이 일반인들에 비해 높다는 공식적 통계는 없으나, 대중문화예술인의 직업적 환경 과 심리적 특성은 스트레스와 관련이 있고, 스트레스는 마음 건강과 자살에 직접적인 영향을 미칠 수 있기 때문에, 본 장에서는 대중문화예술인들의 자살문제 검토에 앞서 이들의 심리적-직업적 특징과 산업구조의 특성을 살펴보았음

\section{1. 대중문화예술인 심리적·직업적 특성}

- 대중문화예술인의 자살과 직업과의 관계

- 연예인의 자살은 일반인의 자살과 마찬가지로 개인의 정신적 문제에서 비롯된 개인적 측면이 많지만, 그 이면을 살펴보면 사회적 문제들과 연관되어 있다고 볼 수 있음

- 대중문화예술인의 자살을 이해하고 그에 대한 대책을 세우기 위해서는, 대중문 화예술인의 직업적인 특성과 사회구조적 특수성의 이해가 전제되어야 할 것임

- 대중문화예술인의 우울증과 사회적 환경

- 이동연(2020)은 연예인들이 편차가 심한 감정노동에 종사하기 때문에 현실에서 의 감정과 연기·무대에서의 감정의 분열이 일반인들보다 매우 크게 나타나며, 불안정한 상태에 있는 감정을 조절하는 데 실패할 경우 우울증에 걸릴 가능성이 매우 높다고 주장함

- 즉, 만들어진 이미지로 인한 공적 자의식(public self-consciousness)과 내면 의 자각일 수 있는 자아정체감(ego-identity) 사이에서의 혼란이 매우 높은 직 업군임(박진희, 2009)

- 연예인들 감정의 양가성은 특수한 상황에 이르면 정신질환으로 전이될 가능성 
이 높으나, 그 여부는 연예인 개인의 기질 뿐 아니라 그들을 둘러싼 사회적 환경 의 상호작용으로 결정될 수 있음

- 자살의 주요 요인이 정신질환일지라도 연예인 자살의 모든 원인을 개인적인 문 제로 단정할 수 없는데, 이는 정상적으로 누릴 수 없는 사생활, 인터넷에서 익명 의 네티즌들에게 당하는 비난과 욕설, 폐쇄적인 인간관계 등 연예인의 특수한 사회적 환경이 연예인 우울증의 원인이 될 수 있기 때문임

- 또한 일반인들은 스트레스 해소를 다양한 방법으로 해결할 수 있는데 반해, 연 예인들은 우울증을 직업상 노출시키기 어렵기 때문에 좌절감, 불안감, 외로움 등을 적절히 해소하기 어려우며, 이것이 축적될 경우 자살이라는 극단적 행동으 로 이어질 수 있음

- 따라서 연예인 자살의 주원인으로 지목되는 우울증의 원인을 사회적 관점에서 파악할 필요가 있음

- 대중문화예술인의 직무 스트레스

- 많은 경험적 연구들이 자살에 가장 큰 영향을 미치는 요인으로 스트레스를 지목 하고 있으며, 스트레스의 수준이 증가할수록 자살 시도가 증가한다는 연구 결과 들이 이를 뒷받침하고 있음(고성은·홍혜영, 2009)

- 연예인 스트레스에 관한 연구에서(박진희, 2009) 일반적으로 연예인들의 스트 레스 정도가 높다고 밝혀졌는데, 이는 인기하락의 부담감과 함께 고용불안정으 로 인하여 느끼는 직무불안정에 대한 스트레스가 주 요인인 것으로 보임

- 엔터테인먼트 시장에서 연예인에게 요구하는 예술적인 끼와 표현력, 창의력, 대 중적 기호에 부합하는 성격 등과 같은 특성은 연예인의 노동 수요-공급 정보를 불명확하게 만들고 있으며, 그로 인해 연예인의 취업은 비정규직이며 불확실성 이 지배하는 노동시장 구조 속에 놓이게 됨(이훈석·전병준, 2012)

- 이주연·김봉환(2012)은 연예인이 갖는 스트레스 특성을 아래와 같이 지적했으 며, 일반인과는 다른 특수한 스트레스가 극단적인 행동을 이끌 수 있다고 주장함

- 인기와 미디어 노출

- 비정규직으로서의 불안정한 직업 환경과 이로 인한 경제적인 압박

- 이미지와 현실과의 간극 
- 루머와 악플

- 감정노동에 따른 감정의 부조화

- 사생활 노출의 부담감과 불규칙한 생활양식

- 이훈석·전병준(2012)는 다음 〈표 2-1〉과 같이 연예인의 생활 및 직무스트레스 를 일반 직장인과 비교하면서, 연예인의 직업이 비정규적 성격이 강하고, 노동 의 강도가 특정 활동 시기에 집중되며, 요구하는 능력은 교육보다는 재능과 끼 이고, 임금은 인기에 비례하는 등 스트레스가 일반인보다 높은 구조적 특성이 있다고 주장함

〈표 2-1〉 연예인과 일반 직장인의 특성 비교

\begin{tabular}{l|c|c}
\hline & 연예인 & 일반 직장인 \\
\hline 정규직 vs. 비정규직 & 비정규직 성격이 강함 & 정규직+비정규직 \\
\hline 프로젝트 조직의 성격 & 강함 & 일상 업무 \\
\hline 프리랜서적 성격 & 강함 & 조직에 소속 \\
\hline 노동의 강도 & 활동시기에 집중 노동 & 보통의 노동 강도 \\
\hline 성수기와 비수기 & 활동시기 사이에 휴식기 & 계약서에 따라 상시 근로 \\
\hline 요구하는 능력 & 재능과 끼 & 직무에 적합한 지식, 기술, 태도 \\
\hline 교육훈련 & 필요에 의해 교육 & 정기적인 교육훈련 \\
\hline 국민연금 & 매우 낮은 가입률(24.9\%) & 의무가입 \\
\hline 고용보험 & 매우 낮은 가입률(18.3\%) & 의무가입 \\
\hline 산재보험 & 매우 낮은 가입률(12.3\%) & 의무가입 \\
\hline 임금 & 인기에 비례 & 조직 내 규정 \\
\hline
\end{tabular}

* 출처: 이훈석, 전병준(2012). ‘방송연예인의 감정노동과 직무스트레스가 직무만족도에 미치는 영향

- 사회적 매개변인의 중요성

- 사회적 지지는 다른 사람들로부터 필요한 지지를 받을 수 있다는 지각이며, 사 회적 지지를 통해 스트레스를 덜 위협적인 것으로 평가하고 스트레스 반응을 감소시켜서 심리적 안녕감을 높일 수 있음(이주연, 김봉환, 2012, 재인용)

- 자살문제 대응에 있어 타인과의 관계 속에서 사랑받고 있다는 믿음과 지지의 요소들은 강력한 설명력을 지니는 것으로 보임

- 연예인에게 과도한 스트레스가 있는 경우에도 부모, 친구 등 사회적 지지의 매개 효과가 충분하다면 자살과 같은 극단적인 상황으로 이어지는 것을 막을 수 있음 
- 그러나 연예인의 특성상 가족 및 친구 간의 관계 변화, 배타적인 업계 내 인간관 계 등으로 인해 스트레스가 자살생각으로 이어지는 과정에서 사회적 지지의 개 입과 소통의 부족이 클 수 있음(이주연·김봉환, 2012)

- 따라서 연예인을 대상으로 하는 상담 및 심리치료의 현장에서는 연예인들에게 적절한 사회적 지지를 제공하는 것이 신체적, 경제적, 사회적 문제를 감소시키 고 개인적인 위기를 벗어나는 데 효과적일 수 있을 것임

\section{2. 대중문화예술산업의 구조적 특성}

- '대중문화예술기획업'이 중심이 되는 산업 구조

- 대중문화예술산업발전법 제2조(정의)에서 '대중문화예술기획업' 은 대중문화예술 인의 대중문화예술용역을 제공 또는 알선하거나 이를 위하여 대중문화예술인에 대한 훈련·지도·상담 등을 하는 영업을 말하며, 일반적으로는 연예인을 발굴·육 성하고, 연예활동을 원활하게 진행할 수 있도록 지원해주는 회사를 일컬음

- 2000년대 이후 한류의 발달로 인하여 기획사들이 대형화 되고 체계적인 기업의 면모를 갖추기 시작했으며, 연습생 발굴, 트레이닝, 프로듀싱, 기획, 마케팅 등 의 업무를 종합적으로 수행하게 되었음

- K-pop 한류를 이끌고 있는 대표적인 3대 기획사 SM, YG, JYP 외에 대중음 악-연기 등과 관련된 기획사는 2020년 7월 현재 총 3,616개사에 이르며 (KOCCA 대중문화예술종합정보시스템 등록기업정보), 이들은 대부분 3 4인으 로 구성된 소규모의 영세한 회사임

- 기획사 시스템의 문제점

- 한류와 함께 '스타'를 양성하는 기획사 시스템이 활성화 되면서, 엔터테인먼트 산업 현장에는 미래 스타를 꿈꾸며 기획사 교육 시스템 내에 소속되어 관리를 받는 집단 연습생들이 증가하고 있으며, 어린 나이에 이미 스타가 되는 경우도 늘어나고 있음

- 기획사 연습생이나 엔터테인먼트 산업의 진입 연령대가 주로 청소년층이라는 점에 주목할 필요가 있는데, 기획사 중심의 시스템에서는 연예인 지망생들이 어 
릴 때부터 매우 엄격한 트레이닝에 몰두하면서 상대적으로 학교 교육에 소홀하 게 되고, 이로 인하여 사회적으로 성숙할 기회가 부족하여 교육과 발달의 균형 이 유지되기 어려운 상황임

- 기획사 시스템이 활성화되면서 합숙생활을 하는 청소년 연습생이나 연예인들도 증가하고 있으나, 이러한 직무환경은 과도한 경쟁과 악플을 견뎌내야 하는 스트 레스 상황에서 부모, 가족, 친구 등 사회적 지지를 제공받는 환경을 조성하지 못함으로써 극단적인 행동으로 이어지기 쉽다는 경고도 있음(권정훈 등, 2012)

- 또한, 미성년인 청소년 시기에 데뷔하여 성년 초기에 활발한 활동을 하는 연예 인들은 일반 청소년층 또래집단과 확연히 다른 청소년 시기를 거치기 때문에, 정서적·사회적으로 미성숙한 상태에서 갑작스럽게 스타가 되고 대중적 관심이 쏟아지는 경우 그것을 소화할 능력이 낮고 스트레스에 대한 적응력이 떨어져 우울증에 빠질 가능성이 높아짐(하재근, 2019)

- 한편, 청소년 연예인 지망생(연습생)들이 실제로 연예인이 될 확률이 매우 낮고, 과도한 경쟁, 정서적 어려움, 학업 중단의 가능성 등을 고려할 때, 대중문화예술 산업 예비 종사자에 대한 보다 적극적인 정책적 관심이 요구됨

- 한국 기획사 시스템에 대한 해외의 비판

- 대중문화예술인의 스타성과 활동이 한류 성공의 핵심 요인이 되고 있고, 이들을 육성·관리 하는 기획사 시스템에 대한 전 세계의 관심이 집중되고 있으나 이에 대한 비판도 함께 증가하고 있음

- 해외 언론들은 K-pop 한류의 화려한 이면에 연습생들의 노예계약, 인권침해, 제한된 자유, SNS 악플 등으로 인한 문제가 상존하고 있음을 지적함

- 더욱이 샤이니의 종현이 2017년 사망하자, 한국 기획사의 연습생 시스템을 비 판하면서, 한국 연예산업의 과도한 경쟁구조와 인권 침해적인 기획사의 트레이 닝·관리의 문제점을 지적하였음 
BBC News $`$ The dark side of South Korean pop music $\lrcorner(2011.06 .15$.

- K-pop의 수출이 국가 위상을 높이고 경제적인 효과를 거둘 것으로 기대한다. 그러나 그 이면에는 장기간 에 걸친 연습생들의 노예계약, 가수들에게 돌아가는 턱없이 부족한 수익금 문제가 있다.

Variety 「Jonghyun Suicide Note Points to Brutal Pressure of Korean Spotlight $\lrcorner$ (2017.12.19.)

- 한국의 연예산업이 잔혹할 정도로 강한 경쟁 구조로 되어 있다. 한국의 엔터테인먼트 산업은 강한 압박으 로 유명하다. 모든 동료가 경쟁자이고, 가장 강한 자만이 살아남는 '헝거게임'과 같은 작업환경을 조성한 다. 한국에서 가수들은 소속사의 엄격한 관리를 받는다. 한편으로 소속사에 의해 엄격하게 관리되고, 또 다른 한편으로 터무니없이 높은 수준의 행동 규범을 요구받으며 소셜 미디어 논평의 물결에 시달린다.

- 1990년대 후반부터 젊은 K-pop 인재들이 잇달아 숨지고 있다. 많은 이들이 우울증을 호소했고 화려한 겉모습 뒤에는 인간의 존엄성을 짓밟는 지독한 산업의 징후를 남겼다.

- 종현의 유서에는 "난 속에서부터 고장 났다. 천천히 날 갉아먹던 우울은 결국 날 집어삼켰고 난 그걸 이길 수 없었다."고 적혀있었는데, 종현의 극단적 선택의 이유가 명확하지 않더라도, K-pop 의 화려한 이면에는 어둠이 존재한다는 것을 보여준다.

The Guardian $\lceil$ Kim Jonghyun: SHINee star dies amid an unforgiving K-pop industry」 (2017.12.18.)

- 빛나는 스타가 배려 없는 케이팝 산업 한가운데 죽다(샤이니 종현), 한국의 아이돌 지망생들 대부분 10 대 초반부터 계약을 맺고 엄격하게 훈련을 받는다. 이중 극히 일부만 데뷔의 기회를 얻는다"고 비판함 


\section{제2절 대중문화예술인 자살 현황}

\section{1. 대한민국 자살 현황}

- 세계 최고 수준의 자살률

- 한국은 2010년 OECD 주요 국가 자살률 순위에서 1위를 차지한 이래 줄곧 1 2위를 차지하면서 '자살'이 커다란 사회적 이슈가 되어 왔음

- 우리나라의 자살률은 2001년 OECD 주요국가 순위에서 7위에 머물렀으나, 급 격한 사회·경제적 변화 속에 자살률이 급속히 상승하여, 2010년과 11년에 1위 에 올랐으며, 2012년부터 2016년까지 리투아니아에 이어 2위를 기록하였음 (중앙자살예방센터 홈페이지1))

- 2018년 자살사망자 수는 13,670명으로 전년 대비 1,207명(9.7\%) 증가하였고, 1 일 평균 자살사망자 수는 37.5 명, 자살률(인구 10 만 명당)은 26.6 명(중앙자살 예방센터)으로, 여전히 세계 최고 수준을 나타내고 있음

- 한국인의 자살 구조

- 2018년도 한국의 자살 현황을 살펴보면, 남성의 자살이 여성보다 2.5배 이상 많으며, 연령별로는 80 대, 70 대가 가장 높아 노년층의 자살이 심각한 사회문제 로 대두되고 있음을 보여줌

- 특히 80대 남성은 인구 10 만 명당 138.5 명, 70 대 남성은 83.2명으로 한국인 전체 평균인 26.6명의 3 5배 이상으로 나타나 노인 문제의 심각성이 드러나고 있음

- 자살률은 연령에 따라 증가하는 추세를 보이고 있으나, 사망원인으로서의 자살 은 낮은 연령에서 더 높은 순위를 차지하였음

1) 중앙자살예방센터(http://spckorea-stat.or.kr/international01.do) 국제 자살통계/OECD 자살통계 
[그림 2-1] OECD 주요국가 20년간 자살률 추이

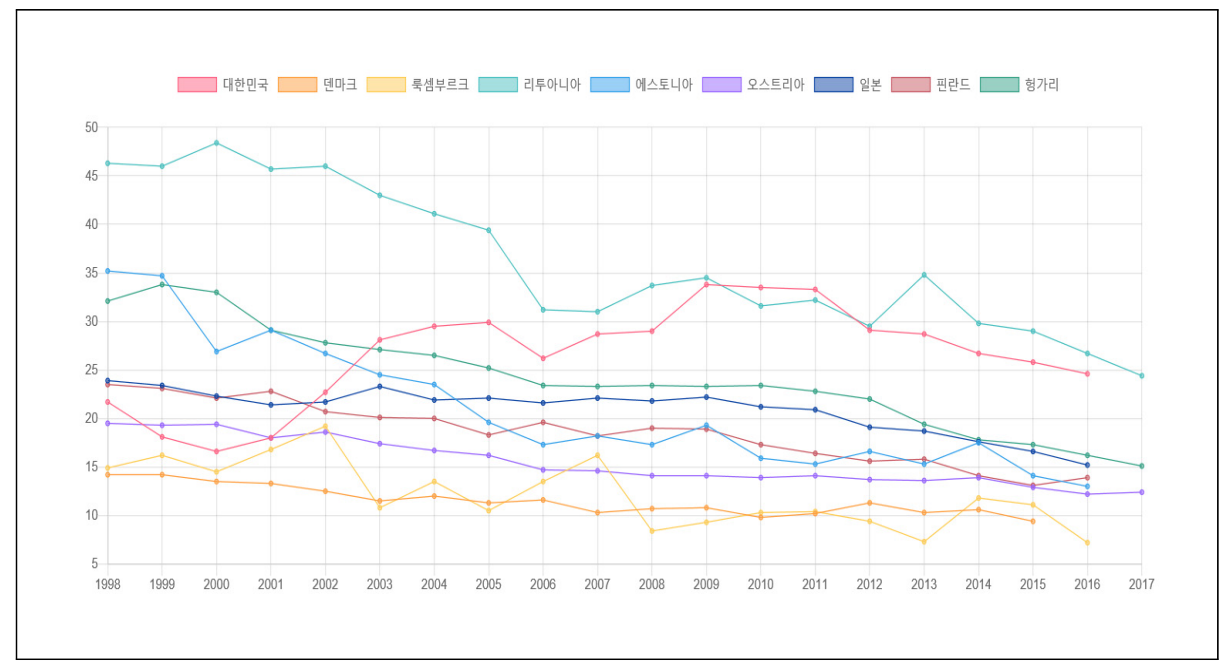

* 출처: 중앙자살예방센터 통계홈페이지(http://spckorea-stat.or.kr/korea01.do)

[그림 2-2] OECD 주요국가 20년간 자살률 추이1987 2018년 성별에 따른 자살률 추이

(단위: 인구 10 만 명당 명)

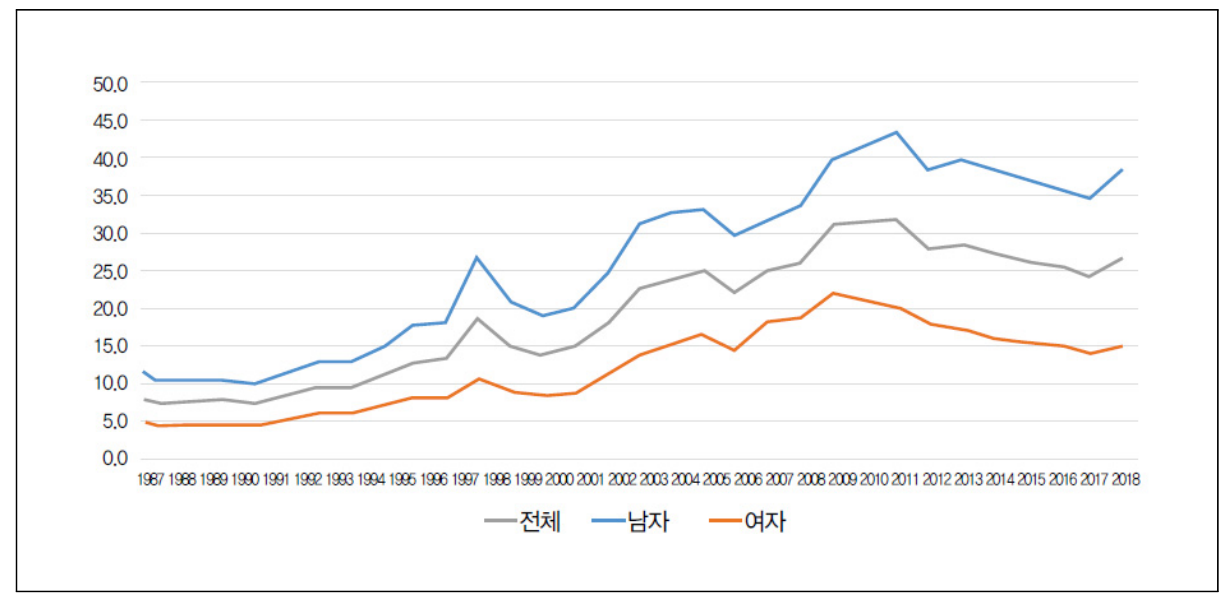

* 출처: 통계청, 1987-2018년 사망원인통계

- 2018년 연령별 사망원인 중 고의적 자해(자살)는 10 30대에서 1위, 40대와 50 대에서는 2 위를 차지했으며, 연령별 전체 사망원인 중 고의적 자해(자살)가 차지하는 비율(구성비)은 10 대 $35.7 \%, 20$ 대 $47.2 \%, 30$ 대 $39.4 \%, 40$ 대 $21.3 \%, 50$ 대 $10.1 \%$ 로 나타나 자살의 심각성을 보여주고 있음(보건복지부, 중 앙자살예방센터, 2020) 
- 자살의 원인은 정신과적 문제(31.6\%)가 가장 주요했으며, 경제생활문제(25.7\%), 육체적 질병문제(18.4\%), 가정문제(7.9\%)가 그 다음 원인으로 파악되었음

- 최근 한국 자살현황의 특이점

- 과거 글로벌 금융위기 때나 국제통화기금(IMF) 외환위기 때는 자살률 증가폭이 각각 $20 \%, 40 \%$ 대로 상승하여, 당시 자살이 경제적 원인과 연계되어 있음을 보 여줌

- 하지만 최근의 자살은 과거처럼 '경제난'에만 기인하지 않으며, 특히 노인이나 중장년층의 경우 은퇴 후 불안감, 가족 간 갈등, 실직, 만성질환 등의 문제가 얽혀 자살이 발생하는 것으로 전문가들은 분석하고 있음

- 최근 자살의 또 하나의 문제는 10대 청소년 자살의 급증으로, 8년째 우리나라 청소년(9 24세)의 사망 원인 1 위가 자살이었음

- 2018년 자살로 사망한 청소년은 10 만 명당 9.1명으로, 같은 기간 안전사고와 암으로 사망한 청소년은 각각 10 만 명당 4.6명, 2.9명임을 감안할 때, 청소년 자살의 심각성을 보여주고 있음

\section{2. 대중문화예술인 자살 현황}

- 대중문화예술인 자살 현황 파악의 어려움

- 중앙자살예방센터2) 에서는 다양한 인구학적 요인(연령, 성, 혼인상태, 교육수 준, 지역 등)에 따른 자살 현황 데이터를 제공하고 있으나 대중문화예술인 직업 군에 대한 별도의 데이터는 제공하지 않고 있어, 대중문화예술인들의 자살률을 타 직업군과 비교할 수 없음

- 이는 대중문화예술인이라는 직업군의 범주가 불명확하고 현실적으로 파악하는 데 어려움이 있기 때문으로 풀이됨

2) 중앙자살예방센터는 「자살예방 및 생명존중문화 조성을 위한 법률_(2011.3.30.)에 근거하여 설치 운영되 고 있는 시설로 자살에 대한 국가적 차원의 책무와 예방정책에 관하여 필요한 사항을 규정함으로써 국민의 소중한 생명을 보호하고 생명존중문화를 조성함을 목적으로 함 
- 사회적 이슈가 된 대중문화예술인 자살

- 대중문화예술인의 자살 중 사회적으로 가장 큰 이슈가 된 사건으로 최진실 자살 (2008. 10.)이 있으며, 2019년에는 설리(2019. 10.), 구하라(2019. 11.) 등이 잇달아 자살하면서 큰 사회적인 이슈로 떠올랐음

- 특히 최근 20대 아이돌 출신 유명 연예인들의 자살은 엔터테인먼트 산업 구조와 그 속에서 육성된 연예인들의 정신건강, 또 이들의 자살이 청소년들에게 미치는 영향 등에서 많은 사회적 질문을 던지고 있음

- 2005년 이후 사회적으로 주목을 받았던 유명 대중문화예술인들의 자살을 살펴 보면 다음과 같음

〈표 2-2〉대중문화예술인 자살 현황

\begin{tabular}{c|c|c|c}
\hline 성명 & 사망일 & 나이 & 직업 \\
\hline 이은주 & 2005. 02. & 26세 & 영화배우 \\
\hline 유 니 & 2007. 01. & 27세 & 탈렌트 \\
\hline 정다빈 & 2007. 02 & 28세 & 탈렌트 \\
\hline 안재환 & 2008. 09. & 37세 & 탈렌트 \\
\hline 최진실 & 2008. 10. & 41세 & 탈렌트, 영화배우 \\
\hline 장자연 & 2009. 03. & 30세 & 탈렌트 \\
\hline 김다울 & 2009. 11. & 21세 & 모델 \\
\hline 최진영 & 2010. 03. & 40세 & 가수, 탈렌트 \\
\hline 채동하 & 2011. 05. & 31세 & 가수 \\
\hline 김지훈 & 2013. 12. & 40세 & 가수 \\
\hline 박용하 & 2010. 06. & 34세 & 탈렌트 \\
\hline 종 현 & 2017. 12. & 28세 & 가수 \\
\hline 설 리 & 2020. 10. & 26세 & 가수(아이돌), 탈렌트 \\
\hline 구하라 & 2020. 11. & 28세 & 가수(아이돌) \\
\hline
\end{tabular}




\section{3. 대중문화예술인 자살의 베르테르 효과}

- 연예인 자살의 영향력에 대한 주목

- '대중문화예술인'직업군에 대한 별도의 자살률을 밝히지는 못하지만, 자살에 대 한 많은 학술적 연구들은 대중문화연예인을 포함한 셀러브리티 자살의 영향에 주목하고 이를 파악하고자 하였음

- 연예인들의 자살이 사회적 문제로 부상하는 것은 연예인 자살자들이 갖는 현실 적 어려움이나 심리적 고통을 일반인들이 동일시하면서 모방 자살을 유도할 가 능성이 높기 때문임(이주연·김봉환, 2012)

- 우리 사회에서 연예인 자살이 모방자살의 양상으로 나타나기 시작한 것은 2005 년 배우 이은주 자살 이후로 보고 있음(이주연·김봉환, 2012)

- 연예인 자살의 베르테르효과에 대한 학술 연구 결과

- 배우 최진실 자살 직후 자살 관련 각종 통계를 살펴보면, 베르테르 효과가 매우 크게 나타난 것을 확인할 수 있음

- 2008년 최진실 사망 다음날의 자살자 수는 78명이었고, 5일째 되는 날에는 90 명 가까이가 자살을 하였는데, 당시 30 명 안팎이었던 하루 평균 자살자 수와 비교해볼 때, 베르테르 효과가 나타났음을 알 수 있음

- 또한 2008년 9월 1,083명이었던 자살자 수가 배우 최진실이 자살한 10월에는 65.6\% 증가한 1,793 명으로 급증하여(통계청 사망원인통계), 연예인의 자살이 일반인에게 큰 영향을 미치고 있음을 보여줌

- 이처럼 연예인 자살의 부정적인 사회적 영향력이 크기 때문에 체계화된 사회적 대책과 정책적 개입이 요구되고 있음 
[그림 2-3] 응급실에 온 자살 시도 환자 수(인구 1만 명당 명)

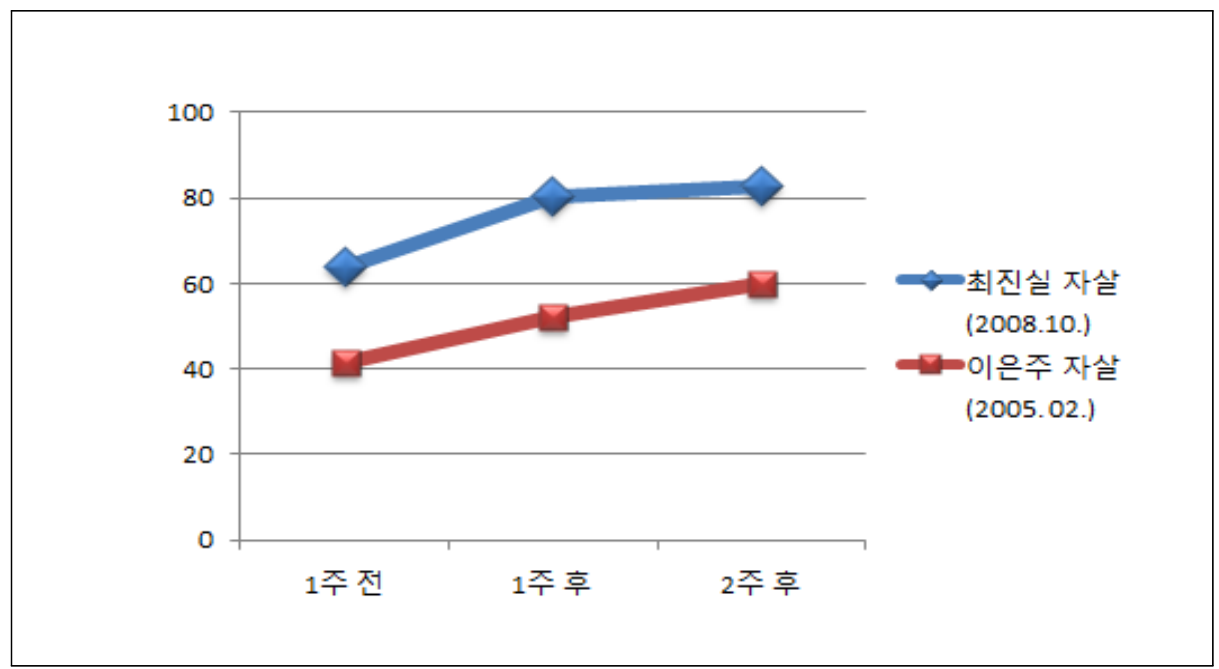

출처: 동아닷컴(2012), 연예인 모방자살은 진실

〈표 2-3〉 유명 연예인 자살 이후 2달간 자살자 수 및 자살 증가효과 추정치

(단위: 명)

\begin{tabular}{l|r|r|r|r|r}
\hline & \multicolumn{1}{|c|}{$\begin{array}{c}\text { 이은주 } \\
\text { 2005.02. }\end{array}$} & $\begin{array}{c}\text { 유니 } \\
2007.01 .\end{array}$ & $\begin{array}{c}\text { 정다빈 } \\
2007.02\end{array}$ & $\begin{array}{c}\text { 안재환 } \\
2008.09 .\end{array}$ & $\begin{array}{c}\text { 최진실 } \\
2008.10 .\end{array}$ \\
\hline $\begin{array}{l}\text { 유명연예인 자살 사건 후 2달간 } \\
\text { 자살자 수(A) }\end{array}$ & 2,258 & 2,330 & 2,304 & 2,876 & 3,081 \\
\hline $\begin{array}{l}\text { 자살사건 전년도 동일기간 } \\
\text { 자살자 수(B) }\end{array}$ & 2.154 & 1,822 & 1,922 & 1,961 & 1,807 \\
\hline $\begin{array}{l}\text { 자살사건 다음 연도 동일 기간 } \\
\text { 자살자 수(C) }\end{array}$ & 1,992 & 1,812 & 1,971 & 2,403 & 2,339 \\
\hline \begin{tabular}{l} 
기대치( $\mathrm{E}=\mathrm{B}$ 와 $\mathrm{C}$ 의 평균) \\
\hline 자살증가 효과 추정치(A-E)
\end{tabular} & 2,073 & 1,827 & $1,981.5$ & 2,182 & 2,073 \\
\hline
\end{tabular}

출처: 보건복지부 외(2020). 「생명존중문화 확산을 위한 영상콘텐츠 자살 장면 가이드라인」

- 자살 방법에 미치는 베르테르효과

- 신미영 등(2010)의 연구에 따르면 유명인의 자살 이후의 영향은 일반인 자살자 수의 증가뿐 아니라, 구체적인 자살 방법에도 미침

- 이들은 2 명의 연예인 자살보도 시점을 기준으로 6 개월, 1 년 전후의 자살 방법을 검토한 결과, 동일한 자살방법을 사용한 자살시도자의 수가 급격히 높아짐을 보 고하였음 
[그림 2-4] 2008년 유명 배우 사망 사건 발행 전후 목맴 자살 사망자 수 연간 추이

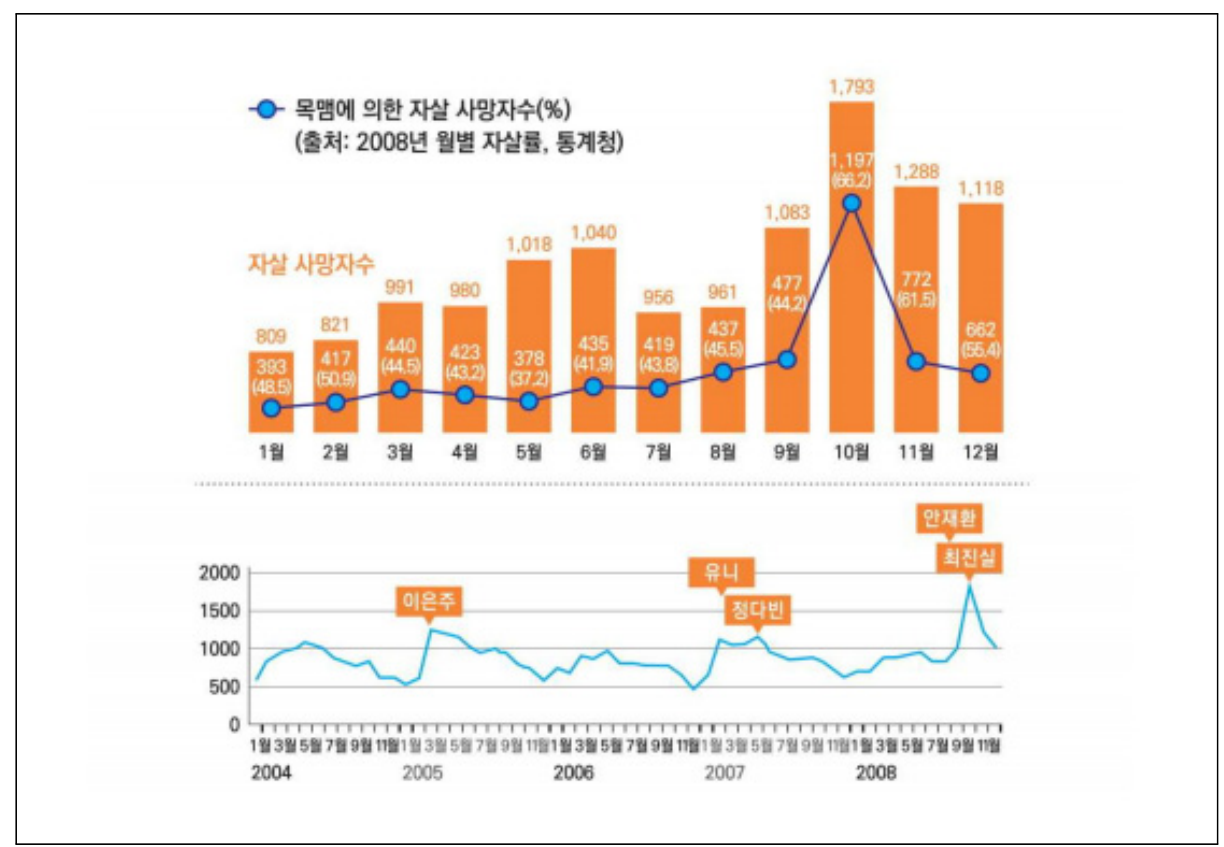

출처: 보건복지부 외, (2020). 생명존중문화 확산을 위한 영상콘텐츠 자살 장면 가이드라인」 


\section{제3절 소결}

- 문화산업의 핵심 자원인 대중문화예술인

- 대중문화예술인은 한류의 기반이 되는 소중한 자산으로서, 세계 시장에서 대중 문화뿐 아니라 국가의 이미지를 높이는 첨병 역할을 담당해왔음

- 이들의 성과는 개인적 성공에 머물지 않고, 국가의 브랜드가 되고 한국과 한국 상품을 홍보하는 등 문화산업과 국가 홍보에서 높은 위상을 갖게 되었음

- 대중문화예술인들의 심리적·직업적 특성

- 하지만, 한류 성장 이후 기획사 중심으로 전개되는 대중문화예술산업 시스템에 서 연예인들은 과도한 경쟁, 인기 하락에 대한 부담감, 직무불안정성, 사회적 지 지의 부족 등으로 인해 일반인들보다 높은 스트레스를 겪고 있는 것으로 나타남

- 더욱이 연예산업에 진입하거나 활동하는 주역들이 청소년이거나 성년 초기로, 일찍이 제도권 교육에서 멀어지고 기획사의 엄격한 관리·감독을 받는 가운데 정서적·사회적으로 균형을 유지하기 힘든 경우가 많음

- 한국 대중문화 산업에 대한 해외의 비판적 시각

- 해외 미디어들은 한국 대중문화예술산업의 화려한 이면에 있는 연예인에 대한 비인격적인 관리 시스템, 과도한 경쟁에 대해 지속적으로 비판해왔음

- 특히 2017년 그룹 샤이니의 멤버 종현의 자살 이후, 한국의 성공적인 대중문화 산업 뒤에 어린 종사자들에게는 '헝거게임'과도 같은 과도한 경쟁과 비인격적 대우 등 대중문화산업시스템에 대한 비판이 높아짐

- 대중문화예술인·대중문화예술산업의 특성과 자살과의 관계

- 대중문화예술인들의 심리적·직업적 특성과 사회적 환경으로 인하여 높은 스트레 스를 겪고 있음에도 불구하고 스트레스 해소를 위한 대응이나 치료에 적극적이 지 못하여 우울증으로 연계되기 쉬우며 극단적인 경우 자살까지 이어지기도 함 
- 대중문화예술인 자살 현황

- OECD 주요국 중 자살률 1 2위를 유지하는 우리나라에서, 최진실부터 설리, 구하라 등으로 이어지는 대중문화예술인의 자살은 심각한 사회적 문제로 부상 하였음

- 대중문화예술인의 자살에 대한 공식적 통계는 없으나, 연예인들의 자살은 일반 인들의 모방 자살을 부추기고 자살 방법에도 영향을 미치는 베르테르 효과가 있어 사회적 관심과 정책적 대응이 요구됨

- 대중문화예술인 자살에 대한 미디어 보도의 영향

- 자살에 대한 미디어의 보도는 방아쇠 촉발기능, 미디어의 단순노출효과로 인한 친숙성 증가, 정당화 기능, 면역효과, 축적효과 등을 유발한다는 문제가 지적되 어 왔고, 이를 방지하기 위한 자살보도 권고기준이 마련되었음

- 하지만, 자살보도 '권고기준'은 강제성이 없고, SNS·블로그·온라인 커뮤니티 등 을 통해 연예인 자살에 대한 정보가 무분별하게 유포되고 있어, 새로운 미디어 환경에 맞는 자살보도 지침이 필요함 

대중문화예술인 자살문제 대응정책 연구

제3장

자살예방 정책 현황 



\section{제1절 자살예방 관련 기관}

\section{1. 보건복지부}

- 보건복지부의 자살예방정책의 시작

- IMF를 거치면서 대한민국의 자살률이 급격히 증가하고 이후 지속적으로 $\mathrm{OECD}$ 국가 자살률 1 위를 기록하자, 보건복지부는 2005년부터 자살 등에 대 한 위기상담전화를 운영하고, 2006년부터 생명사랑 및 자살예방사업 등 자살예 방정책을 시작함

- 자살예방 관련 법률 제정 및 본격적인 자살예방정책 전개

- 보건복지부는 2004년 〈제 1 차 국가자살예방 5 개년 기본계획〉을 수립하면서 본 격적인 자살예방사업을 전개하였으며, 2011년 3월 30일 「자살예방 및 생명존 중 문화 조성을 위한 법률」을 제정하여 자살예방정책의 기반을 마련하였음

- 2014년에는 법률에 근거하여 〈국가 정신건강증진 마스터플랜(2016 2020)〉을 수립하였으며, 2020년 내로〈2021 2025년 정신건강 5개년 기본계획〉을 준 비·발표할 예정임

- 자살예방과 신설

- 문재인 정부는 '자살예방 및 생명존중문화 확산'을 국정과제에 포함한 이후, 성 과가 입증된 구체적인 해결방안을 담은 〈자살예방 국가행동계획(' 18 '22)〉을 수립하였고, 효과적인 자살예방정책 기획·추진을 위해 복지부 건강정책국 내에 '자살예방정책과'를 신설하였음

- 보건복지부의 자살예방 주요 정책

- 보건복지부는 자살이 개인의 문제가 아니라 국가적으로 해결 가능한 사회 문제 라는 인식을 바탕으로 자살예방정책을 수행하며, 각 부처와 지방자치단체, 자살 
예방 관련 다양한 민간위탁기관이 업무를 유기적으로 수행할 수 있도록 지원하 고 있음

- 또한 '자살예방 국가행동계획'의 과제로서 자살자 전수조사, 자살 고위험군 발 굴, 1 차 의료기관 등을 통한 선별·치료 연계 체계 강화, 응급실 자살시도자 사 후관리 기관 확대(' 17 년 42 개 $\rightarrow$ ' 1 년 63개), 자살유발정보 차단 및 자살수단 관리, 자살예방법 개정 추진 등을 수행하고 있음

〈표 3-1〉 보건복지부 자살예방정책과 주요 업무
1. 자살예방에 관한 종합계획의 수립 및 조정
2. 연도별 자살예방 시행계획에 따른 추진실적 평가에 관한 사항
3. 자살의 원인분석 및 실태조사에 관한 사항
4. 자살예방을 위한 조사·평가 및 연구에 관한 사항
5. 자살예방 사업 및 프로그램의 개발
6. 자살예방 관련 법령에 관한 사항
7. 자살예방 관련 인식개선 및 지원에 관한 사항
8. 자살예방 전문 인력의 양성 및 지원에 관한 사항
9. 자살 고위험군 발굴 및 대응체계 구축에 관한 사항
10. 자살 고위험군 지원 및 사후관리에 관한 사항
11. 자살자의 가족 지원에 관한 사항
12. 자살과 관련한 언론 모니터링 및 자살유해정보 확산 예방에 관한 사항
13. 지방자치단체 및 민간의 자살예방 사업 활성화 및 지원에 관한 사항
14. 자살수단 관리 등 자살위험 해소를 위한 관계기관 간 협력 체계 구축

출처: 보건복지부, 중앙자살예방센터(2020). 2020 자살예방백서」

- 자살예방 기본계획

- 보건복지부는 2004년 12월 〈제1차 국가자살예방 5개년 기본계획〉을, 2008년 12월에〈2차 자살예방종합대책('09 '13)〉을 수립·시행하였음

- 2011년 3월 11년 「자살예방 및 생명존중에 관한 법률」이 제정되면서 보건복지 부는 그동안 법적근거 없이 추진되던 기존의 자살예방종합대책을 수정·보완하 여, 법적·재정적 기반에 근거한 5개년 계획을 수립하고 국가적 차원의 자살예방 사업체계를 더욱 강화하였음

-〈제3차 자살예방 기본계획(생명사랑플랜〉의 주요 내용

- 2016년에〈제3차 자살예방 기본계획(생명사랑플랜)〉이 발표되었는데, 여기에 는 2020년까지 5년간의 자살 예상 국가전략과 정책 방향을 담고 있었음 
- 자살예방 기본계획은 2020 년까지 인구 10 만 명당 자살률을 20 명으로 낮추는 것 을 주요 목표로 하였으나, 현재 상황으로는 목표 달성이 어려울 것으로 보임

- 〈자살예방 국가행동계획〉의 주요 내용

- 2018년 1월에 수립된 〈자살예방 국가행동계획〉은 기존에 발표된 자살예방 기 본계획을 보완하며 실효성 있는 과제를 중심으로 구체적인 행동계획을 제시하 고 있음

- 이를 위해 총리실 주도의 범정부 추진체계를 구축, 범부처의 협조를 강조하며, 과학적 근거에 따른 전략적 접근을 위한 자살사망자 전수조사 실시 등의 내용을 담고 있음

- 본 계획은 2017년부터 2022년까지 인구 10만 명 당 자살률을 2016년 대비 $30 \%$ 감소된 17 명으로 낮추는 것을 목표로 함

〈표 3-2〉 자살예방 기본계획 및 국가행동계획

\begin{tabular}{|c|c|c|c|c|}
\hline \multirow{2}{*}{ 구분 } & \multirow{2}{*}{ 시기 } & \multirow{2}{*}{ 주체 } & \multicolumn{2}{|c|}{ 목표자살률(인구10만명 당) } \\
\hline & & & 계획 & 결과 \\
\hline $\begin{array}{c}\text { 제1차 } \\
\text { 자살예방 기본계획 }\end{array}$ & $2004-2008$ & 보건복지부 & $\begin{array}{c}\text { 18.2명 } \\
\text { (2010년) }\end{array}$ & $\begin{array}{c}\text { 31.2명 } \\
\text { (2010년) }\end{array}$ \\
\hline $\begin{array}{c}\text { 제2차 } \\
\text { 자살예방 기본계획 }\end{array}$ & 2009-2013 & 보건복지부 & $\begin{array}{l}\text { 20.0명 } \\
\text { (2013년) }\end{array}$ & $\begin{array}{c}\text { 28.5명 } \\
\text { (2013년) }\end{array}$ \\
\hline $\begin{array}{c}\text { 제3차 } \\
\text { 자살예방 기본계획 }\end{array}$ & $2016-2020$ & 보건복지부 & $\begin{array}{c}\text { 20.0명 } \\
\text { (2020년) }\end{array}$ & $\begin{array}{c}\text { 미발표 } \\
\text { (2021예정) } \\
\end{array}$ \\
\hline 자살예방 국가행동계획 & $2018-2022$ & $\begin{array}{c}\text { 보건복지부 } \\
\text { 총리실 }\end{array}$ & & \\
\hline
\end{tabular}

출처: 보건복지부, 중앙자살예방센터(2020). 「2020 자살예방백서」

- 세부추진과제

- 자살예방 기본계획의 추진과제는 크게 '범사회적 자살예방환경 조성', '맞춤형 자살예방 서비스 제공', '자살예방정책 추진기반 강화' 등으로 구분되며, '맞춤 형 자살예방 서비스 제공'의 세부 과제 내 자살 고위험군 지지체계 강화 사업에 연예인 상담지원 사업이 포함되어 있음

- 또한 자살예방 인력 확충 사업의 일환으로 추진되는 생명지킴이(게이트키퍼) 양 성 사업, 자살예방 서비스 제공자 심리지원 사업 등은 대중문화산업계 현장과의 연계가 가능할 것으로 파악됨 
[그림 3-1] 보건복지부 및 관련 기관의 자살예방사업 협력체계

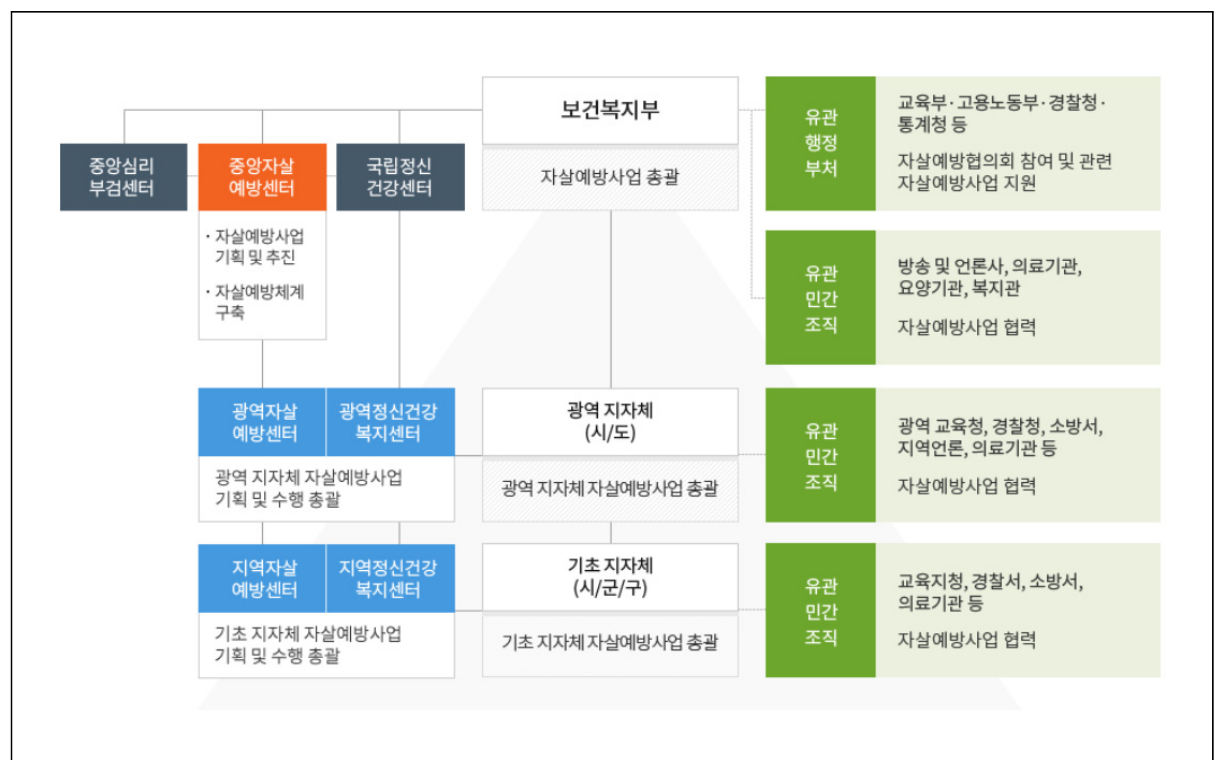

출처: 중앙자살예방센터 홈페이지(http://wnw.spckorea.or.kr/sub.php?menukey=27)

\section{2. 자살예방정책위원회}

- 자살예방정책위원회의 출발

- 2018년 자살예방 및 생명존중문화 조성을 위한 법률 제10조의2(자살예방정책위 원회) (2018년 개정)를 근거로 국무총리실 소속으로 자살예방정책위원회를 둠

- 자살예방정책위원회의 역할

- 자살예방정책위원회는 자살예방정책의 중장기 정책목표와 추진, 기본계획 수립, 추진실적 평가, 부처 간 협조·조정, 민관협력 등에 관한 사항을 심의함

- 자살예방정책 추진 실적 평가

- 위원회는 자살예방법에 따라 2021년부터 정책의 지속적 개선·보완을 위한 중앙 부처 추진실적 평가계획안을 마련하였으며, 평가결과는 2021년 위원회에서 최 종확정할 예정임 


\section{3. 한국자살예방협회3)}

- 한국자살예방협회의 설립

- 한국자살예방협회는 2003년 12월에 창립되었으며, 2004년 4월 민법 제32조 및「보건복지부 및 그 소속청 소관 비영리법인의 설립 및 감독에 관한 규칙」 제4조에 의거하여 설립허가를 얻은 단체임

- 한국자살예방혐회 설립 목적

- 한국자살예방협회는 “생명존중정신”의 이념철학에 기초하여 자살로부터 안전한 사회를 만들어 가는 것을 비전으로 하고 있음

- 비전 실현을 위해 자살예방교육과 홍보활동 전개, 자살예방을 위한 프로그램 개 발 및 연구, 정책적 제안을 위한 다양한 조직화 활동 전개, 사회에 생명존중 정

신 구현 등을 목적으로 함

- 주요 사업

- 주요 사업으로 자살예방교육사업, 농약안전보관함보급사업(4), 자살예방프로그램 개발 및 사업 점검, 관련 연구 및 학술활동, 정책제안 등의 활동을 전개하고 있음

\section{4. 중앙자살예방센터}

- 중앙자살예방센터의 설립배경

- 보건복지부 주도의 자살예방 종합대책과 민간의 자살예방 활동에도 불구하고 국가 자살률이 세계 최고 수준을 지속하자, 국가 차원의 자살예방사업 추진을 위해 중앙자살예방센터를 설립하였음

- 근거 법률

- 중앙자살예방센터는 「자살예방 및 생명존중 문화 조성을 위한 법률」 제13조(자 살예방센터의 설치)에 근거하여 2012년에 설치되어 현재 운영 중에 있음

3) 한국자살예방협회 홈페이지: http://suicideprevention.or.kr/01_sub/02_sub.html

4) 농약안전보관함보급사업은 자살의 수단으로 사용되는 맹독성 농약에 대한 접근성을 차단하기 위한 방안으 로 전개되고 있는 사업임 
〈표 3-3〉 중앙자살예방센터 설치의 법적 근거

자살예방 및 생명존중문화 조성을 위한 법률(약칭:자살예방법)

제13조(자살예방센터의 설치) (1) 다음 각호의 업무를 수행하기 위하여 보건복지부장관은 중앙자살예방센터를, 시·도지사 및 시장·군수·구청장(자치구의 구청장을 말한다)은 지방자살예방센터(이하 "자살예방센터"라 한

다)를 설치·운영할 수 있다.

1. 자살 관련 상담

2. 자살위기 상시현장출동 및 대응

3. 자살시도자 사후관리

4. 자살자의 유족 지원 및 관리

5. 자살예방 보호 및 교육

6. 자살예방 전문 인력 양성

7. 그 밖에 자살예방 및 자살자의 유족 지원을 위하여 보건복지부장관이 필요하다고 인정하는 업무

- 중앙자살예방센터의 역할 및 활동 내용

- 중앙자살예방센터의 미션은 생명을 존중하는 사회를 조성하고, 모든 개인의 생 명존중 의식을 고양하는 것임

- 중앙자살예방센터는 사회 각계 민관 협력기관과 네트워크를 구축하는 등 대외 협력 사업을 진행하고, 자살예방 홍보 및 교육, 미디어정보 관련 사업, 자살예방 전문인력 양성, 연구개발 및 통계분석 등 자살예방사업을 추진함

- 구체적인 사업으로 '자살통계 및 데이터 제공, 자살예방백서 발간', '프로그램 인증', ‘지역 맞춤형 자살예방 사업 컨설팅', ‘국가 자살동향 시스템 교육', ‘유해 정보 모니터링', '생명지킴이 교육', '자살예방 협력체계 구축 \& 매뉴얼 개발', '자역자치단체 자살예방 사업 평가 \& 컨설팅', '응급실 사후관리', '자살예방 주 간행사 등이 있음

- 자살예방 프로그램 인증제 운영

- 자살예방 프로그램에 대한 객관적 검증을 통해 자살예방 프로그램의 질적 향상 을 도모하고, 근거기반의 자살예방 프로그램을 확산하여 자살예방 프로그램의 효과성을 제고함

- 2021년 자살예방사업 여부가 정부 부처의 평가에 반영되고, 특히 인증 프로그 램의 사용여부가 평가에 중요하게 작용하기 때문에, 향후 문화체육관광부의 대 중문화예술인 대상 자살예방 프로그램을 개발할 경우 중앙자살예방센터로부터 인증을 획득하여야 할 것임 
[그림 3-2] 자살예방센터의 신규 자살예방 프로그램 인증과정

자살예봥 프로그램

인중 신정
자살에방 프로그램

인중 심사
자살에방 프로그램

인중
인증프로그램

보급

\section{5. 중앙심리부검센터}

- 중앙심리부검센터의 설립 배경

- 보건복지부는 근거기반 자살예방정책 수립을 위해 2014년 중앙심리부검센터를 설립함

- 중앙심리부검센터의 역할 및 사업

- 중앙심리부검센터는 자살 사망자의 사망원인을 다각도로 분석하고 자살 유족을 지원 역할을 수행하고 있음

- 구체적인 사업으로 심리부검을 통한 자살사망원인 분석, 자살 유족 사후관리 강 화를 위한 지원, 자살 유족 지원을 위한 홍보, 경찰 수사기록·건강보험자료를 활용한 분석 등을 수행하고 있음

\section{6. 광역 및 기초 자살예방센터/정신건강복지센터}

- 광역 및 기초 자살예방·정신건강복지센터 개요

- 광역 자살예방.정신건강복지센터는 지역사회 내 자살예방사업을 기획 및 수립, 조정, 수행하는 기관으로 현재 전국 9 개의 광역자살예방센터와 16 개의 광역정 신건강복지센터가 운영되고 있음

- 광역 및 기초 자살예방·정신건강복지센터의 역할

- 지역사회 내 정신건강서비스 및 자살예방을 위한 기반을 구축하고, 지역사회 특 성 및 욕구에 적합한 예방, 치료 재활 서비스가 제공될 수 있도록 유관기관 간 연계 및 서비스 제공 체계를 마련함 
- 지역 특성을 반영한 사업추진체계를 구축하고, 지역사회 내 정신건강서비스 및 자살예방사업 미충족 계층 대상자에 대한 서비스 연계체계 구축 및 프로그램을 운영하며, 지역사회정신건강사업을 위한 자문 및 지원을 제공함

〈표 3-4〉정신건강복지센터의 역할

\begin{tabular}{|c|c|c|}
\hline 영역 & 광역정신건강복지센터 & 기초 정신건강복지센터 \\
\hline 기획 & $\begin{array}{l}\text { · 지역사회 진단 및 연구조사 } \\
\text { • 서비스 평가체계 구축 }\end{array}$ & $\begin{array}{l}\text { • 지역사회 진단 } \\
\text { · 기획 및 자원 조정 }\end{array}$ \\
\hline $\begin{array}{l}\text { 중증정신질환 } \\
\text { 관리 }\end{array}$ & $\begin{array}{l}\text { · 편견 해소 사업 } \\
\text { · 24시간 위기관리 지원 } \\
\text { · 초발정신질환관리체계 구축 } \\
\text { · 탈원화 전달체계 구축 } \\
\text { · 프로그램 개발 및 지원 } \\
\text { · 노숙정신질환 관리 }\end{array}$ & $\begin{array}{l}\text { - 신규 발견체계 구축 } \\
\text { · 사례관리서비스 } \\
\text { - 위기관리 서비스 } \\
\text { · 주간재활프로그램 } \\
\text { · 직업재활 프로그램 } \\
\text { · 주거서비스 네트워크 구축 }\end{array}$ \\
\hline $\begin{array}{l}\text { 정신건강 } \\
\text { 증진사업 }\end{array}$ & $\begin{array}{l}\text { - 인식개선 사업 } \\
\text { - 24시간 상담 및 지원 } \\
\text { - 자살위기개입 체계 운영 } \\
\text { · 프로그램 개발 및 지원 } \\
\text { · 고위험군 조기검진 지원 } \\
\text { · 교육 프로그램 개발 및 교육지원 }\end{array}$ & $\begin{array}{l}\cdot \text { · 홍보 및 교육사업 } \\
\text { • 1577-0199 상담전화 } \\
\cdot \text { · 고위험군 조기발견과 치료 연계사업 } \\
\text {-어린이 청소년 } \\
\text {-성인 우울증, 스트레스 } \\
\text {-노인 우울증 및 치매 } \\
\text {-알코올 중독 }\end{array}$ \\
\hline $\begin{array}{l}\text { 정신보건 } \\
\text { 환경조성 }\end{array}$ & $\begin{array}{l}\text { - 사회안정망 구축 지원 } \\
\text { • 언론 네트워크 구축 및 지원 }\end{array}$ & $\begin{array}{l}\text { • 보건복지 네트워크 구축 } \\
\text { • 자원봉사운영체계 구축 } \\
\text { • 지역언론 협력체계 구축 } \\
\text { • 경찰 및구조구급 네트워크 }\end{array}$ \\
\hline
\end{tabular}

(https://mww.mohw.go.kr/react/policy/index.jsp?PAR_MENU_ID=06\&MENU_ID=06330401\&PAGE=1\&topTitle=)

\section{7. 한국예술인복지재단}

- 한국예술인복지재단의 설립 및 역할5)

- 한국예술인복지재단은 2012년 「예술인복지법」에 따라 '예술인의 복지에 대한 체계적이고 종합적인 지원을 하여 예술인들의 창작활동을 증진하고 예술발전에 기여함을 목적으로 설립되었음

- 한국예술인복지재단은 전략 목표로 예술인의 권익제고, 예술인의 생활안전망 지원, 예술인의 가치 확산 등을 내세움

5) 한국예술인복지재단 홈페이지: http://www.kawf.kr/intro/sub02.do 
- 예술인에 대한 심리상담 프로그램 제공6)

- 예술인 지원 사업 중 하나로 예술인 심리상담을 제공하고 있으며, 지원 사항에 는 12 회의 심리상담 및 심리검사와 문화예술 관련 협.단체 단위의 집단 심리상 담 비용 지원, 예방과 위기개입 프로그램, 자살예방 교육등이 포함되어 있음 - 지원 대상은 예술창작활동 과정에서 심리적·정신적 스트레스를 겪고 있는 예술 인·예술인 복지법상 예술인임

- 대중문화예술인에 대한 지원의 어려움

- 한국예술인복지재단에서 지원하는 예술분야에 영화, 연예(방송, 공연)가 포함되 어 있어 대중문화예술인들도 예술인 심리상담 프로그램 지원 대상이 되나, 대중 문화예술산업계는 이러한 사실을 대부분 인지하지 못하고 있음

- 한국예술인복지재단의 예술인 심리상담 프로그램 운영에 있어서도 실질적으로 대중문화예술인을 지원한 사례가 거의 없는 것으로 보임

\section{8. 대중문화예술인지원센터7)}

- 대중문화예술인지원센터의 설립 및 역할

- 대중문화예술산업발전법은 건전한 대중문화를 확립하고 국민의 문화적 삶의 질 향상에 이바지함을 목적으로 하는 법으로, 본 법의 제 17 조(지원센터)에서 대중 문화예술인, 대중문화예술제작물스태프 및 대중문화예술기획업 종사자의 권익 보호를 위한 지원센터 설립을 명시하였음

- 이를 근거로 2011년 문화체육관광부는 2011년 한국콘텐츠진흥원 내에 대중문 화예술인지원센터를 개소함

- 대중문화예술산업발전법에 대중문화예술인지원센터의 세부 역할로 상담 및 법률 적 지원과 권익보호를 위한 교육 프로그램 운영, 대중문화예술제작물스태프의 직 업능력 개발 및 교육 지원, 업무의 홍보 등을 규정하고 있어, 지원센터 내에서 자 살예방 교육 프로그램을 제공하고 운영하는 것에 대한 법적 근거가 마련되어 있음

6) 한국예술인복지재단 홈페이지: http://www.kawf.kr/intro/sub02.do

7) 대중문화예술인지원센터 홈페이지: http://www.kocca.kr/cop/contents.do?menuNo=200987 
- 현재 대중문화예술인지원센터에서는 대중문화예술산업발전법 제26조와 제29 조를 근거로 대중문화예술기획업자에 대해 대중문화예술산업발전법의 내용과 준수사항, 대중문화예술산업의 공정한 영업질서의 조성에 관한 사항, 청소년 대 중문화예술인 보호, 그 밖에 대통령령으로 정하는 사항, 사회 이슈로 대두된 각 종 문제 예방교육(성범죄 및 폭력 예방, 연예인 자살 등)을 실행하고 있음

- 또한 대중문화예술산업발전법 제19조와 제21조를 기반으로 청소년 연예인·연 습생 소양교육 및 심리상담을 진행하고 있으나, 그 대상이 ‘청소년'으로 제한되 어 있으며 20세 이상의 성인 연예인은 대상에 포함되지 않음

\section{〈표 3-5〉대중문화예술인지원센터 설립 및 예술인 지원과 관련된 법적 근거}

\section{대중문화예술산업발전법 제17조(지원센터)}

(1) 문화체육관광부장관은 대중문화예술인, 대중문화예술제작물스태프 및 대중문화예술기획업 종사자의 권익보 호를 위한 지원센터(이하 “지원센터"라 한다)를 설치할 수 있다.

(2) 지원센터는 다음 각 호의 업무를 한다.

1. 실태 및 권익보호를 위한 국내외 제도조사

2. 불공정거래, 폭력 등 피해 상담 및 법률적 지원

3. 성폭력 등의 방지를 위한 긴급전화센터 연계 및 지원

4. 권익보호를 위한 교육 프로그램 운영

5. 대중문화예술제작물스태프의 작업능력 개발 및 교육 지원

6. 업무의 홍보 및 그 밖에 지원센터의 설치목적을 달성하는 데 필요한 사업

대중문화예술산업발전법 제19조(청소년보호 원칙)

국가, 대중문화예술사업자, 친권자 또는 후견인은 청소년 대중문화예술인이 대중문화예술용역을 제공하는 경우 그 권익이 침해되지 아니하도록 하며, 건전한 인격체로 성장할 수 있도록 배려하여야 한다.

\section{대중문화예술산업발전법 제21조(청소년의 대중문화예술용역 제공)}

(1) 대중문화예술사업자가 청소년 대중문화예술인과 계약을 체결하는 경우 그 대중문화예술인의 신체적·정신적 건강, 학습권, 인격권, 수면권, 휴식권, 자유선택권 등 기본적 인권을 보장하는 조치를 계약에 포함하여야 한다.

\section{대중문화예술산업발전법 제26조(대중문화예술기획업의 등록)}

(1) 대중문화예술기획업을 하려는 자는 문화체육관광부장관에게 등록하여야 한다.

요건 나. 문화체육관광부령으로 정하는 시설에서 실시하는 대중문화예술기획업 관련 교육과정의 이수

\section{대중문화예술산업발전법 제29조(대중문화예술기획업자의 교육)}

(1) 문화체육관광부장관은 대중문화예술기획업자에 대하여 이 법의 내용과 준수사항, 대중문화예술산업의 공정한 영업질서의 조성에 관한 사항, 그 밖에 대통령령으로 정하는 사항 등에 관한 교육을 실시할 수 있다.

(2) 제26조제1항에 따라 등록한 대중문화예술기획업자는 제1항에 따른 교육을 받아야 한다.

(3) 문화체육관광부장관은 제1항에 따른 교육실시를 대통령령으로 정하는 전문기관 또는 협회 등에 위탁할 수 있다. 이 경우 문화체육관광부장관은 예산의 범위에서 필요한 비용의 전부 또는 일부를 지원할 수 있다.

(4) 대중문화예술기획업자는 성에 대한 건전한 가치관 함양과 성폭력·성매매·성희롱 방지를 위하여 소속 대중문 화예술인이 대통령령으로 정하는 전문기관이 실시하는 성교육 및 성폭력·성매매·성희롱 예방교육을 받을 수 있도록 필요한 조치를 하여야 한다. 〈신설 2020. 6. 9.〉

(5) 제 1 항 및 제 4 항에 따른 교육의 시기·시간-내용 및 비용 등에 관하여는 문화체육관광부령으로 정한다. 〈개정 2020. 6. 9.) 
〈표 3-6〉 대중문화예술기획업자 교육 프로그램 개요

\begin{tabular}{c|c|c}
\hline 구 분 & $\begin{array}{c}\text { 최초교육 } \\
\text { (등록 이후 최초 } 1 \text { 회 이수) }\end{array}$ & $\begin{array}{c}\text { 연간교육 } \\
\text { (최초교육을 받은 후 다음연도부터 매년) }\end{array}$ \\
\hline 교육시간 & 6시간 & 3시간 \\
\hline 교육운영 & 위탁운영(1개 기관) & 문체부 지정 확인단체 중 3개 기관 위탁운영 \\
\hline 교육방식 & 오프라인 교육 & 오프라인/온라인 교육 \\
\hline 교육규모 & 약 400 개 기업 & 약 2,700개 기업 \\
\hline
\end{tabular}

* 출처: 대중문화예술인지원센터 내부자료(2020. 06.)

〈표 3-7〉 대중문화예술기획업자 교육 프로그램 개요

\begin{tabular}{|c|c|}
\hline 구분 & 교육 프로그램 \\
\hline $\begin{array}{c}\text { 온라인 연간교육 } \\
\text { (2020년) }\end{array}$ & $\begin{array}{l}\text { - 콘텐츠 산업 종사자 성희롱 예방 교육 } \\
\text { - 소속 연예인이 겪는 심리적 어려움과 대처 방법 } \\
\text { - 대중문화예술인 사이버 폭력 예방 및 대응 방법 } \\
\text { - 대중문화예술기회ㅇㅓㅓ 종사자를 위한 법률 에센스 } \\
\text { - 대중문화예술기획업 종사자를 위한 세무 기초 } \\
\text { - 대중문화예술인 병적별도관리제도 안내 }\end{array}$ \\
\hline $\begin{array}{c}\text { 2018 2019년 교육 } \\
\text { 프로그램 }\end{array}$ & $\begin{array}{l}\text { - 대중문화예술산업발전법과 기획업자 준수의무 등 } \\
\text { - 저작권과 초상권 } \\
\text { - 연예인과 바람직한 커뮤니케이션 } \\
\text { - 병무청 제도안내 } \\
\text { - 전속계약 분쟁사례 및 예방 } \\
\text { - 심리코칭 } \\
\text { - 공연기획 특강 }\end{array}$ \\
\hline
\end{tabular}

* 출처: 대중문화예술인지원센터 내부자료(2020. 06.)

- 대중문화예술인지원센터 심리상담 현황

- 대중문화예술인지원센터는 청소년 연예인, 연습생 등을 대상으로 심리상담을 진행하고 있는데, 실제로 상담을 받은 대다수는 청소년 연습생임

- 최근 3년간(2017 2019년) 청소년 연예인 연습생 심리상담 이용자 수는 〈표 3-8>과 같음

- 이용자의 만족도 조사는 2019년에 처음 실시하였는데, 5점 만점에 4.75점으로, 이용자들의 만족도는 높은 것으로 나타남

- 상담 횟수는 지원 인원 증가보다 더 높은 비율로 증가하였는데, 이는 심리검사 실시로 최소 3회 이상 심리상담을 받을 수 있도록 사업을 개선하였기 때문임(대 중문화예술인지원센터 담당자 인터뷰) 
- 하지만, 1 인당 심리검사 1 회를 제외한 상담 횟수가 2 회에 불과하여 실질적으로 심도 깊은 심리상담이 진행되었다고 보기는 어려움

- 또한 상담 대상이 주로 청소년 연습생에게 한정되어 있어, 활동 중인 청소년 연 예인나 성인 연예인들은 지원의 사각지대에 놓일 수 있으며, 연예인과 항시 함 께 활동하며 커뮤니케이션을 하는 매니저들 역시 상담의 대상에 포함시켜야 할 것으로 보임

〈표 3-8〉 대중문화예술인지원센터 심리상담 이용자 수

\begin{tabular}{c|c|c|c}
\hline 구분 & 2017년 & 2018년 & 2019년 \\
\hline 지원인원(명) & 120 & 73 & 111 \\
\hline 상담횟수(회) & 167 & 146 & 329 \\
\hline 상담전문가(명) & 3 & 3 & 3 \\
\hline
\end{tabular}

출처: 대중문화예술인지원센터 내부자료(2020. 06.)

\section{9. 시사점}

- 국무총리실, 보건복지부 및 산하 기관에서 자살예방과 관련한 정책 개발 및 지원 사업 실시

- 국무총리실 소속 자살예방정책위원회, 보건복지부 자살예방과, 중앙자살예방센 터, 한국자살예방협회 등 정부 부처 및 민간 협회에서 자살예방 관련 업무를 수 행 중임

- 대중문화예술인 자살 대응 정책 수립 및 사업 개발에 이들 기관과의 적극적 협 업이 필요할 것으로 보임

- 정부 부처의 자살예방정책 추진실적이 부처 평가에 반영될 예정임

- 2021년부터 부처 평가에 자살예방정책 추진 실적이 반영되므로, 문화체육관광 부에 특화된 자살예방정책 마련 및 사업 추진이 시급히 요청되는 상황임

- 한국예술인복지재단 대중문화예술인지원센터의 한계

- 한국예술인복지재단이 운영하는 상담, 자살예방 교육 등의 프로그램에 대중문 화예술인들도 지원 가능하나, 실질적인 이용은 거의 없는 것으로 보임 
- 현재 예술인복지재단의 개인상담 프로그램이 1 인당 12 회이며, 온라인을 통해 신청하면 지정된 상담센터에 직접 연계가 가능하도록 되어 있는 시스템은 대중 문화산업계에서 적극 도입해야 할 것임

- 한국콘텐츠진흥원 대중문화예술인지원센터의 한계

- 대중문화예술인지원센터의 주 업무는 대중문화예술기획업 등록제도 운영, 법률 상담, 표준계약서, 공정거래, 갈등조정 프로그램 등이며, 예술인들의 심리상담 은 일부 업무에 불과함. 담당자 역시 정신건강이나 심리상담의 전문성을 갖추지 못함

- 심리상담은 인원과 횟수(3회)에 제한이 있으며, 외부 상담사에 대한 신뢰도도 높지 않은 편임. 자살예방교육은 매니저 교육 프로그램에 포함되어 있으나 자주 운영되지는 않았음

- 자살예방 교육의 실효성을 제고하기 위해서는 대중문화예술기획업자의 교육 프 로그램에 자살예방교육을 필수과목으로 지정해야 하며, 이를 위해 관련 법 개정 (대중문화예술산업발전법 제29조)이 필요할 것으로 보임 


\section{제2절 자살예방을 위한 교육 및 사업}

\section{1. 자살예방 교육}

- 자살예방 교육의 기본 관점: "자살은 예방 가능한 것"

- 많은 연구들은 일반 대중교육 및 인식개선, 정신질환 치료, 치명적 자살수단의 접근 제한, 언론 보도 모니터링 등을 통해 자살의 상당수를 예방 가능한 것으로 보고하고 있음

- 자살예방을 위한 근본적인 접근은 구성원들의 정신건강을 위해 통합적인 심리 적 서비스 및 교육을 지원하는 것이며, 자살예방 교육은 자살에 대한 국민들의 인식을 개선하고 자살예방 및 생명존중문화를 조성함으로써 실질적인 자살예방 효과를 높이고자 함

- 자살예방 교육을 통한 게이트키퍼(Gate keeper) 양성

- 게이트키퍼는 자살의 위험에 처해 있는 사람들과 빈번한 접촉을 갖는 사람들 중 자살 위험이 있는 대상자를 인지하고 발견하여 전문가에게 의뢰할 수 있는 능력을 교육받은 자를 일컬음

- 자살예방을 위한 여러 정책 중 게이트키퍼 양성을 통한 지역사회 자살의 조기 발견과 개입은 대부분의 나라에서 핵심적인 자살예방정책의 하나로 꼽히고 있 음(백종우 외, 2014)

- 게이트키퍼 교육은 자살 가능자의 가족, 친구, 이웃 등의 미시체계(micro system)와 동료집단사이의 관계, 지역사회 구조 등의 중간체계(meso system) 를 활용함으로써 예방 대책의 효과를 높이도록 한 것으로(조계화, 김영경, 2008) 지역사회의 구성원이 자살 위험군을 발견하고 위험 정도를 평가하여 전 문가에게 의뢰하는 것을 목표로 함 
- 게이트키퍼 교육의 출발

- 1978년 미국 워싱턴주에서 Spokane 정신보건센터에서 동료 게이트키퍼 교육 프로그램이 개발되었는데, 당시에서는 큰 효과가 나타나지 않았지만 다양한 계 층에서의 게이트키퍼 교육 프로그램이 꾸준히 개발되고 실행되면서 그 효과가 점차 드러나기 시작하였음

- 그 결과 1992년 미국 질병통제센터(The Centers for Desease Control)는 자 살예방에 효과적인 8가지 전략 중 하나로 게이트키퍼 교육 프로그램을 제안하 였으며, 이후 세계적으로 다양한 계층에서 게이트키퍼 교육 프로그램이 활발하 게 실시되고 있음

- $\mathrm{WHO}$ 는 자살예방 실천 전략으로 자살 수단에 대한 접근성 제한, 의료서비스 접근성 증대, 매체의 보도 방침, 고위험 집단에 대한 개입과 더불어 게이트키퍼 양성을 제안하고 있음(중앙자살예방센터, 2017)

- 중앙자살예방센터는 자살예방 교육의 초점을 자살위기자를 파악하고, 자살 고 위험군에 직접 개입할 수 있는 게이트키퍼를 교육·양성하는 것에 맞추고 있으 며, 군대, 청소년, 노인 등 다양한 계층에 적합한 게이트키퍼 교육 프로그램을 개발·실행하고 있음

- 게이트키퍼 교육의 효과성

- 게이트키퍼 교육 프로그램의 효과성은 대표적으로 미국 공군의 게이트키퍼 훈 련으로 자살관련 위험요소를 33\% 감소시켰다는 보고(중앙자살예방센터, 2017) 를 비롯하여, 스웨덴, 독일, 헝가리, 일본 등에서 일차의료진에 대한 교육이 자 살률 감소에 기여했다는 다수의 연구를 통해 증명되었음(백종우 외, 2014)

- $\mathrm{WHO}$ 는 게이트키퍼 훈련 프로그램 참여자들이 자살을 예방하는데 기여한다고 보고하였으며(중앙자살예방센터, 2018), 미국질병통제센터(CDC)도 자살예방 에 대한 효과적인 전략으로 게이트키퍼 교육을 제안하였음

- 한국은 2013년 개발된 한국형 게이트키퍼 교육 프로그램인[보고 듣고 말하기] 프로그램의 효과성 평가에서, 14 세 이상 청소년과 성인 참여자 중 $95 \%$ 가 교육 을 받은 이후 자살에 대한 위험 신호를 보이는 주변 사람으로부터 자살을 생각 하게 된 이유를 들어 주었고, 그 중에서 $71.5 \%$ 가 도움을 받을 수 있도록 정보를 
제공하고 네트워크를 연결해 줌으로써 자살예방에 기여하였다고 보고되어(백종 우 외, 2014) 프로그램의 효과성이 증명됨

- 또한 한국 공군의 경우 공군 전체를 대상으로 2015년부터[보고듣고말하기]프 로그램을 의무적으로 실시하고, 지휘관, 참모들은 ASIST 프로그램을 이수하도 록 하고 있는데, 프로그램 도입 이전보다 이후의 자살 사고가 대폭 감소한 것으 로 나타나 프로그램의 실질적인 효과성을 높이 평가받고 있음(권순정, 2020) - 게이트키퍼 양성 프로그램은 불특정 다수보다 교육 내용이 집단 특성에 맞춤형 으로 개발 운영될 때 효과가 높다고 보고되고 있어(WHO, 2014), 국내 게이트 키퍼 프로그램인[보고듣고말하기]의 경우 일반인용, 직장인용, 청소년용, 공군 용으로 집단 특성에 맞춤형으로 개발되었으며, 또 다른 게이트키퍼 교육 프로그 램인[이어줌인]의 경우도 청소년, 대학생, 성인, 노인, 직장인을 구분하여 교육 대상에 맞게 프로그램을 개발하여 교육의 효과를 높이고 있음

- 국내 게이트키퍼 교육 정책 추진 현황

- 보건복지부는 제1차 자살예방 종합대책(2003 2008)과 제2차 자살예방 종합대 책(2009 2013)을 수립하면서 게이트키퍼 교육을 주요한 정책의 하나로 추진 하기 시작함

- 2013년부터 중앙자살예방센터의 책임 하에 전국적으로 게이트키퍼 교육을 시 작하였으며, '2018년 자살예방 국가행동계획'에서는 게이트키퍼 100만 명 양 성을 목표로 하고(중앙자살예방센터, 2018), 2020년 현재까지 100만 명 이상 의 게이트키퍼를 육성하였음

- 자살예방 교육 프로그램의 질적 향상을 위한 프로그램 인증제도

- 효과성이 검증된 자살예방 교육 프로그램의 부재로 자살예방 사업의 질 저하 문제가 대두되면서 자살예방사업의 효과성 증대를 위한 자살예방 프로그램 인 증제도의 필요성이 제기되었음

- 중앙자살예방센터는 프로그램 인증제도를 확립하고, 객관적 검증을 통하여 자 살예방 프로그램의 질적 향상을 도모하고, 근거기반의 자살예방 프로그램을 확 산하여 프로그램 효과성을 증대하고자 하였음(중앙자살예방센터, 2020)

- 2020년 현재 38개의 자살예방 프로그램이 정부 인증을 받았으며, 대표적인 인 
증 프로그램으로는 2013년 한국자살예방협회와 중앙자살예방센터에서 개발한

[보고 듣고 말하기] 프로그램과 2018년 개발된 [이어줌인] 프로그램 등이 있음 (중앙자살예방센터, 2020)

\section{[보고듣고말하기] 프로그램}

- 한국의 게이트키퍼 교육 프로그램이 외국의 프로그램을 일부 그대로 사용하면서 교육 내용에 우리의 사회문 화적인 특성을 반영하지 못한다는 지적이 일자, 2012년 한국자살예방협회, 보건복지부 등이 우리나라 상황 에 맞는 표준화된 한국형 자살예방교육 프로그램[보고듣고말하기]프로그램을 개발하였음

- [보고듣고말하기] 프로그램에서는 게이트키퍼를 '생명사랑지킴이'로 명명하였으며, 생명사랑지킴이 양성을 통해 주변에서 자살 고위험군을 발견하고 개입하며 전문가에게 의뢰할 수 있도록 교육하여 궁극적으로 고위 험군의 자살시도 및 자살률을 감소시키고자 하였음

- 프로그램 교육 대상은 전 국민이나, 대상의 특성에 따라 일반인용, 직장인용, 청소년용, 공군용 등 집단 맞춤형으로 개발되어 교육의 효과를 높이고자 하였음(중앙자살예방센터, 2018)

〈표 3-9〉 국가인증 게이트키퍼 교육 프로그램(보고듣고말하기, 이어줌인) 구성

\begin{tabular}{|c|c|c|c|c|}
\hline 교육명 & 대상 & 시간 & 인원(최대) & 교육내용 \\
\hline \multirow{3}{*}{$\begin{array}{l}\text { 보고 } \\
\text { 듣고 } \\
\text { 말하기 }\end{array}$} & 일반인용 & 180분 & 200명 & \multirow{3}{*}{$\begin{array}{l}\text { - 보기: 자살을 암시하는 언어적, 행동적, 상황적 신호 } \\
\text { 확인 } \\
\text { - 듣기: 실제 자살 생각을 묻고 죽음의 이유와 삶의 } \\
\text { 이유 경청 } \\
\text { - 말하기: 안전점검목록을 확인하고 전문가에게 도움 } \\
\text { 의뢰 }\end{array}$} \\
\hline & 청소년용 & 50 분 & 50명 & \\
\hline & 직장인용 & 110분 & 200명 & \\
\hline \multirow{5}{*}{$\begin{array}{l}\text { 이어 } \\
\text { 줌인 }\end{array}$} & 직장인용 & 60분 & 200명 & $\begin{array}{l}\text { - 자신의 마음을 어떻게 챙길 것인지와 힘든 동료를 } \\
\text { 발견하고 도움을 주는 것을 다룸 }\end{array}$ \\
\hline & 노인용 & 50 분 & 200명 & $\begin{array}{l}\text { - 노인의 특성과 자살 위험 요인을 파악하고 자살 생 } \\
\text { 각을 묻고 들어 주며 도움을 요청할 수 있는 방법을 } \\
\text { 시청각 형태로 구성하여 집중력을 높임 }\end{array}$ \\
\hline & 청소년 & 50분 & 50명 & \multirow{3}{*}{$\begin{array}{l}\text { - 청소년, 대학생, 성인의 상황에 맞게 개발됨. } \\
\text { - 자살위험의 단서를 발견하여 도울 수 있는 방법을 } \\
\text { 배우고 역할연습을 하는 것으로 구성됨. 자살을 생 } \\
\text { 각하는 이들을 발견하고 개입하는 모습을 영상으로 } \\
\text { 보여줌 }\end{array}$} \\
\hline & 대학생용 & 60 분 & 200명 & \\
\hline & 성인용 & 110분 & 200명 & \\
\hline
\end{tabular}

*출처: 중앙자살예방센터(2020). https://wmw.spckorea.or.kr/ 


\section{2. 자살예방 홍보 사업}

\section{가. 대중문화예술인 자살에 대한 미디어 보도의 영향}

- 미디어의 자살보도가 일반인 자살에 미치는 영향

- 미디어에서의 자살에 대한 반복적 노출은 자살에 대한 사고와 행동을 억제하는 인지체계를 약화시키는 탈억제(disinhibition) 작용을 하며, 특히 심신이 취약 한 계층에서 평소 잘 누르고 있는 자살에 대한 생각이 갑작스럽고 강력한 반동 으로 튀어나올 수 있음

- 자살에 대한 미디어 보도는 자살 충동을 자극하는 방아쇠 촉발 기능(trigger effects)이 있으며, 이는 오랫동안 실증적으로 검증되어 왔음

- 자살 기사가 많아지고 오랫동안 반복되면 미디어의 단순노출효과(mere exposure effects)나 정당화 기능(legitimacy function), 면역효과(immunoaffiliation effects), 축적효과 등을 통해 자살을 특별히 비정상적인 것이 아닌 흔히 있는 일반적인 현상으로 인식시키며 정당화시키는 문제가 발생함(임상원, 2009)

- 자살자를 영웅화하거나 자살 행동을 아름답게 표현하는 등 자살을 미화하는 맥 락의 미디어 보도는 자살을 강화(reinforcement)시킴

- 잠재적 자살자의 경우, 자살 관련 보도에 나오는 자살자의 자살 방법이나 원인, 장소 등을 통해 자살 관련 정보를 얻기도 하고 자살자에 대해 공감 혹은 동조하 거나 자살충동을 느끼기도 하는 것으로 밝혀짐(김병철, 2010)

- 미디어 보도가 청소년 자살에 미치는 영향

- 미디어의 자살보도는 청소년의 자살생각에 영향을 미치며, 이는 자살 실행에 까 지 영향을 미칠 수 있다는 연구결과들도 보고되고 있음

- 미디어에서 자살 지역 및 장소에 대한 정보를 제공할 경우, 장소에 낙인효과를 만들어 지역민에게 심적-물적 타격을 주며, 일명 자살명소로 자살 고위험군을 이끄는 작용도 하는데, 청소년이나 동일한 문제를 갖고 있는 대상군에게 이러한 정보의 영향이 크기 때문에 특히 위험함

- 모방효과가 크게 나타나는 청소년들에게 연예인 자살에 대한 미디어 보도는 성 인보다 큰 영향을 미칠 수 있어(오지희, 김민정, 2020) 더욱 주의가 요구됨 


\section{참고: 오스트리아 비엔나 지하철 자살자 수의 변화}

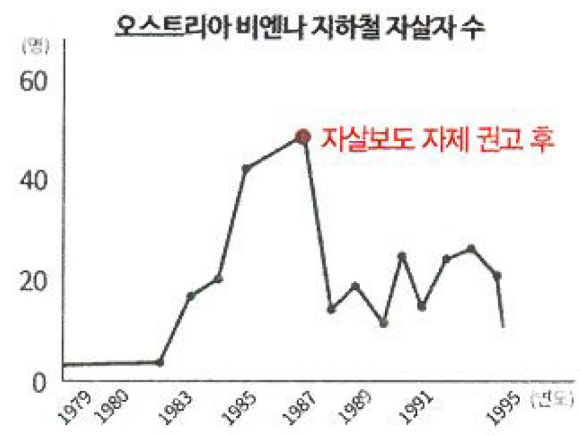

- 1983년 오스트리아 비엔나에서 지하철 자살사건이 발생하고 이것이 언론에 선정적으로 집중 보도되면서 자살자 수가 급증하였음

- 이에 오스트리아 자살예방협회(OVSKK)가 언론 보도가 자살에 미치는 영향을 연구하고, 그 결과에 기반하 여 언론에 자살보도 지침을 따라 보도를 자제해줄 것을 요구하였음. 대부분의 언론이 이 권고를 받아들여 자살보도를 중단하자, 이후 지하철역이 늘고 이용자 수가 증가하였음에도 불구하고 지하철 자살자 수는 $75 \%$ 급감하였음

출처: 중앙자살예방센터 교육자료

\section{나. 자살보도 권고기준 3.0 제작 및 확산}

- 자살보도 권고기준

- 자살보도 권고기준은 TV·신문·인터넷 등 미디어에서 다루는 자살보도가 자살을 생각하는 사람들에게 실행의 시발탄이 될 수 있음을 언론사가 인지하고, 자살 사 건을 다룰 때 언론이 예민하고 책임감 있게 다루기 위한 고려 사항을 제시한 것임 - 자살보도 권고기준은 2004년에 처음으로 발표되었으며, 2013년에는 '자살보도 권고기준 2.0'이 마련되었으나, 자살보도 기준에 뚜렷한 법적 근거가 없어 다수 자살사건 보도에서 자살보도 권고기준이 준수되지 않고 있는 것이 지적되었음8)

- 보건복지부와 중앙자살예방센터, 한국기자협회는 2018년 '자살보도 권고기준 3.0 '을 발표하고, '자살'에 대한 언론 보도에 있어 주의해야 할 사항을 구체적으 로 적시하였음

8) 2018 년 정춘숙 의원실 


\section{자살보도에는 사회적 책임이 따릅니다.}

〈자살보도 권고기준 3.0〉은 자살보도의 사회적 책임을 인식하고, 언론과 개인이 자살예방에 동참할 것을 권유하고자 마련한 기준입니다. 이 기준은 신문, 방송, 인터넷 매체를 포함한 모든 미디어와 경찰과 소방 등 국가기관, 그리고 개인의 사회 관계망 서비스 계정(SNS), 블로그, 온라인 커뮤니티 등에서도 유의해야 하는 기준입니다.

\section{잘못된 자살보도는 사람을 죽게 할 수도 있습니다.}

자살보도는 모방자살을 일으킬 수 있습니다. 자살의 동기나 방법, 도구, 구체적인 장소 등을 보도하면 막연 하게 자살을 고민하던 사람들에게 동일하거나 유사한 방법 또는 장소에서 자살을 실행하도록 부추길 수 있 습니다. 자살 원인을 단정하는 보도는 비슷한 처지의 사람들에게 자살을 하나의 대안으로 선택하게 만들 수 있습니다. 특히 유명인의 자살보도는 파급효과가 크므로 더욱 신중해야 합니다.

\section{자살보도 방식을 바꾸면 소중한 생명을 구할 수 있습니다.}

〈자살보도 권고기준 2.0〉 발표 이후 언론의 자살보도 방식이 변화하면서 자살률은 꾸준히 감소하였습니다. 자살을 고민하는 사람들에게 도움을 줄 수 있는 기관이나 활동을 소개하면 많은 생명을 구할 수 있습니다.

출처: 보건복지부, 중앙자살예방센터, 한국기자협회(2018), 「자살보도권고기준 3.0」

\section{〈표 3-11〉 자살보도 권고기준 3.0의 5가지 원칙}

\section{자살보도 권고기준 3.0 5가지 원칙}

1 기사 제목에 '자살'이나 자살을 의미하는 표현 대신 '사망', '숨지다'등의 표현을 사용합니다.

- 자살을 예방하려면 자살 사건은 되도록 보도하지 않습니다.

- 자살 사건을 주요 기사로 다루지 않습니다.

- 기사 제목에 '자살'이나 자살을 암시하는 표현 대신 사망 사실을 알리는 표현을 합니다.

- 자살이 확정되지 않은 상태에서 자살로 단정 지어 보도하지 않습니다.

- 자살과 관련된 자극적이거나 긍정적이니 표현을 삼갑니다.

2 구체적인 자살 방법, 도구, 장소, 동기 등을 보도하지 않습니다.

- 범죄 사건을 다루듯 자살 방법, 도구, 장소 등을 구체적으로 보도하지 않습니다.

- 자살 동기를 단순화한 보도는 매우 위험합니다.

- 목적자의 인터뷰 내용이나 경찰.소방 등 관련 기관의 발표라도 신중하게 보도합니다.

- 특히 유명인의 자살보도는 파급력이 크므로 더욱 신중해야 합니다.

(3) 자살과 관련된 사진이나 동영상은 모방자살을 부추길 수 있으므로 유의해서 사용합니다.

- 자살 사건과 관련된 영상 자료 사용을 자제합니다.

- 유명인 자살의 경우 사진이나 영상 자료 사용에 각별한 주의가 필요합니다.

- 자살 사건 보도 시 자살예방 관련 기관 정보나 긴급 도움 요청 관련 이미지를 제공합니다.

- 이러한 원칙은 인터넷 방송, 1 인 방송 등에서도 엄격히 준수해야 합니다.

4 자살을 미화하거나 합리화하지 말고, 자살로 발생하는 부정적인 결과와 자살예방 정보를 제공합니다.

- 자살을 합리화 하거나 극적으로 묘사하지 않습니다.

- 다른 사람을 살해하고 자살하는 행위를 '동반자살’로 표현하지 않습니다. 
- 자살로 인해 고통이나 문제에서 벗어났다는 식으로 표현하지 않습니다.

- 자살을 사회적 문제를 제기하는 수단으로 보도하는 경우에도 신중해야 합니다.

- 자살로 발생하는 부정적 결과를 알립니다.

- 자살예방을 위한 보도를 합니다.

5 자살 사건을 보도할 때에는 고인의 인격과 유가족의 사생활을 존중합니다.

- 유가족의 심리 상태를 고려하여 세심하게 배려해야 합니다.

- 고인의 인격과 비밀은 살아있는 사람처럼 보호해야 합니다.

- 유가족의 신분을 노출할 위험이 있는 정보는 보도하지 않습니다.

- 유서와 관련된 사항을 보도하는 것은 최대한 자제합니다.

※ 유명인 자살보도를 할 때 이 기준은 더욱 엄격하게 준수해야 합니다.

출처: 보건복지부, 중앙자살예방센터, 한국기자협회(2018). 「자살보도권고기준 3.0」.

〈표 3-12〉 자살예방 및 생명존중문화 조성을 위한 법률

\section{제19조의2(자살보도 권고기준 준수 협조요청)}

(1) 보건복지부장관은 자살사건 보도로 인한 자살의 확산을 방지하기 위하여 방송·신문·잡지 및 인터넷신문 등 언론에 대하여 제7조제2항제13호에 따른 자살보도에 대한 권고기준을 준수하도록 협조를 요청할 수 있다.

(2) 언론은 제 1 항에 따른 협조요청을 적극 이행하도록 노력하여야 한다.

- 자살보도 권고기준 강제 이행의 어려움

- 현재「자살예방 및 생명존중문화 조성을 위한 법률」의 자살보도에 관련된 조항 에서 보건복지부장관은 자살보도에 대한 권고기준을 준수하도록 협조를 요청할 수 있다고 규정하고, 언론은 협조요청을 적극 이행하도록 노력해야 한다고 적시 되어 있으나, 이는 '권고기준'이며, 불이행에 대한 처벌이 규정되어 있지 않아 자살보도 권고기준의 강제 이행은 어려운 상황임

- 뉴미디어에 대한 자살보도 대책 필요

- 최근에는 인터넷 미디어의 증가로 연예인 자살의 총 보도량은 오히려 증가하고 있으며, SNS·블로그·온라인 커뮤니티 등을 통해 연예인 자살에 대한 정보들이 확대 재생산되고 있으나, 뉴 미디어의 자살보도에 대한 대응책은 전무한 실정임

- 따라서 새로운 미디어 환경에 맞는 자살보도 지침과 자살보도 지침 준수에 대한 모니터링의 필요성이 증가하고 있음 
- '설리법'(정보통신망법 개정안) 발의

- 2019년 10월, 걸그룹 출신 배우 설리의 자살을 계기로, 자살 원인으로 거론되 고 있는 악성 댓글을 차단해야 한다는 여론이 있었고, 이에 대해 박대출 의원 등이 악성댓글 방지를 위한 '정보통신망 이용촉진 및 정보보호 등에 관한 법률 일부개정안'을 발의하였으나, 20대 국회에서 마무리되지 못하였음

- 개정 내용은 이용자가 게시판의 게시글 및 댓글 등의 매개 수단을 통하여 정보통 신망에 따른 정보를 유통할 때에 정보통신서비스 제공자로 하여금 해당 이용자 의 정보통신서비스 이용 아이디(이용자식별부호) 및 인터넷 프로토콜 주소를 함 께 표시하도록 하고 정보통신서비스 제공자가 이를 위반할 시 3천만 원 이하의 과태료에 처하도록 하고자 하였음(안 제 44 조의5 및 제76조제1항제6호의 신설)

- 그러나, 소위 '설리법'은 게시판의 '본인확인제’를 의무화 하는 것으로 이용자의 정보를 공개함으로써 이용자의 개인정보 자기결정권을 제한하며, 이용자의 개 인정보 보호를 약화시킨다는 우려의 의견도 있었음(최시억, 2019)

- 포털의 연예뉴스 댓글 폐지

- 설리법은 20대 국회에서 통과되지 못하였으나, 2020년 네이버, 다음, 네이트 등의 포털 3사는 연예뉴스에 대한 댓글을 폐지하였음

- 댓글 서비스 폐지 이후 포털 연예뉴스에서 악플이 잠시 줄어드는 듯 했으나, $\mathrm{SNS}$, 유튜브, 인스타그램DM 등에서 더 노골적이고 직접적인 악플이 증가하고 있어 이에 대한 대책 마련이 요구되고 있음

〈표 3-13〉 미국의 자살보도 권고기준

- 미국은 자살 관련 여러 기관들이 협력하여 자살보도와 관련한 권고안을 제안하였음

- 자살 연구 결과에 따르면, 자살에 대한 언론 보도는 심적으로 취약한 개인의 자살률 높일 수 있으며, 자살률증가는 보도의 양, 기간, 중요도에 관계가 있다고 밝힘

- 또한 보도가 자살 방법을 구체적으로 묘사하거나 드라마틱하고 그래픽을 활용한 헤드라인이나 이미지를 사용하고, 자살을 선정적 혹은 미화하여 반복적이고 광범위하게 보도하는 경우 자살의 위험이 증가한다 고 밝힘

- 하지만 자살관련 보도는 신중하게 함으로써 대중의 잘못된 인식을 바꿀 수 있으며, 위험에 처한 심적으로 취약한 이들이 갖고 있는 자살에 대한 근거 없는 믿음을 정정할 수 있다는 취지하에 제작되었음 


\begin{tabular}{|c|c|}
\hline Instead of This (비추천) & Do This (바람직한 방법) \\
\hline - 크고 선정적인 헤드라인, 혹은 자극적인 노출 & $\begin{array}{l}\text { - 선정적이지 않은 방향으로 자살을 알리고 자극적인 노출은 } \\
\text { 최소화 함 }\end{array}$ \\
\hline $\begin{array}{l}\text { - 사망 장소나 방법, 가족 친구들의 애도장면, 장례식 혹 } \\
\text { 은 추모식을 포함하고 있는 사진/영상 }\end{array}$ & $\begin{array}{l}\text { - 학교/직장이나 가족 사진을 이용(핫라인 로고나 지역위기 } \\
\text { 관리센터의 전화번호 포함) }\end{array}$ \\
\hline $\begin{array}{l}\text { - ‘급격한 상승, 급속한 유행' 등이나 다른 강한 표현을 사용 } \\
\text { 하여 최근에 일어난 자살들을 묘사하는 것 }\end{array}$ & $\begin{array}{l}\text { - 가장 최신의 } \mathrm{CDC} \text { 데이터를 신중히 살피고 선정적이지 않 } \\
\text { 은 단어를 취사선택하여 사용 }\end{array}$ \\
\hline $\begin{array}{l}\text { - 자살을 ‘설명이 불가능한', 혹은 ‘조짐이 없었던’ 것으로 } \\
\text { 설명하는 것 }\end{array}$ & $\begin{array}{l}\text { - 기사에 자살의 ‘위험 징후’나 ‘해야 할 일’ 등을 포함시키는 } \\
\text { 것 }\end{array}$ \\
\hline $\begin{array}{l}\text { - ‘000가 남긴 자살 노트에 따르면...'. 과 같은 자극적인 } \\
\text { 설명 }\end{array}$ & $\begin{array}{l}\text { - ‘사망자가 남긴 노트가 발견되었고 이는 검시관(의학적 전 } \\
\text { 문가)이 검토하고 있는 중이다’라는 식으로 객관적 사실만 } \\
\text { 을 명시함 }\end{array}$ \\
\hline - 자살조사와 보도가 범죄 보도와 유사하게 취급되는 것 & - 자살을 공공의 건강에 관한 사안으로 보도하는 것 \\
\hline $\begin{array}{l}\text { - 자살의 원인에 관해 경찰이나 첫 응답자를 인터뷰/인용 } \\
\text { 하는 것 }\end{array}$ & - 자살예방전문가에게 조언을 구하는 것 \\
\hline $\begin{array}{l}\text { - 자살을 ‘성공적', '성공적이지 않은' 혹은 '실패한 시도' } \\
\text { 등으로 표현하는 것 }\end{array}$ & $\begin{array}{l}\text { - '자살로 사망하였다' 혹은 '완성된 (completed)' 혹은 ‘스 } \\
\text { 스로를 죽인 것’으로 표현하는 것 }\end{array}$ \\
\hline
\end{tabular}

* 출처: World Health Organization. (2017). Preventing suicide: A resource for media professionals

\section{다. 영상콘텐츠 가이드라인9) 제작 및 배포}

- 영상콘텐츠 자살 장면의 문제

- 영상콘텐츠에 구체적으로 묘사된 자살 장면은 영상이 갖는 힘 때문에 심각한 부작용을 일으킬 수 있음

- 자살 장면이 미디어에 자주 등장함으로써 대중이 자살을 대수롭지 않은 일로 여기게 될 수 있으며, 모방 자살의 원인이 될 수 있음

- 또한 영상콘텐츠에서 자살을 문제 해결의 수단으로 제시하는 것도 유사한 문제 를 가진 사람의 자살을 부추길 수 있으며, 특히 감수성이 예민한 청소년들에게 미치는 효과가 크기 때문에 더욱 주의를 해야 함

- 영상콘텐츠 자살 장면 가이드라인 작성 취지

- 세계보건지구(WHO)와 많은 국가들은 언론 보도는 물론 영상콘텐츠에서의 자 살 장면 역시 신중하게 표현할 것을 권고하고 있음

9) 영상콘텐츠 가인드라인은 보건복지부, 중앙자살예방센터, 한국방송작가협회, 생명존중정책 민·관협의회 (2019)가 제작·발표한 「생명종준문화 확산을 위한 영상콘텐츠 자살 장면 가이드라인」의 내용을 정리한 것임 
- 보건복지부, 중앙자살예방센터, 한국방송작가협회 등은 표현의 자유를 최대한 존중하면서도 영상콘텐츠의 자살 장면에 영향을 받아 생명을 잃는 일을 막고자 2018년 영상콘텐츠 자살 장면 가이드라인을 발표하였으며, 이를 통해 방송과 인터넷 등 영상콘텐츠에서 자살 장면을 신중하게 묘사할 것을 권고하고 있음

- 영상콘텐츠 자살 장면 가이드라인 4원칙

- 자살 방법과 도구를 구체적으로 묘사하지 않음

- 자살을 문제 해결 수단으로 제시하거나 미화하지 않음

- 동반자살이나 살해 후 자살과 같은 장면을 지양함

- 청소년 자살 장면은 더욱 주의해야 함

[그림 3-3] 영상콘텐츠 자살 장면 가이드라인 4원칙

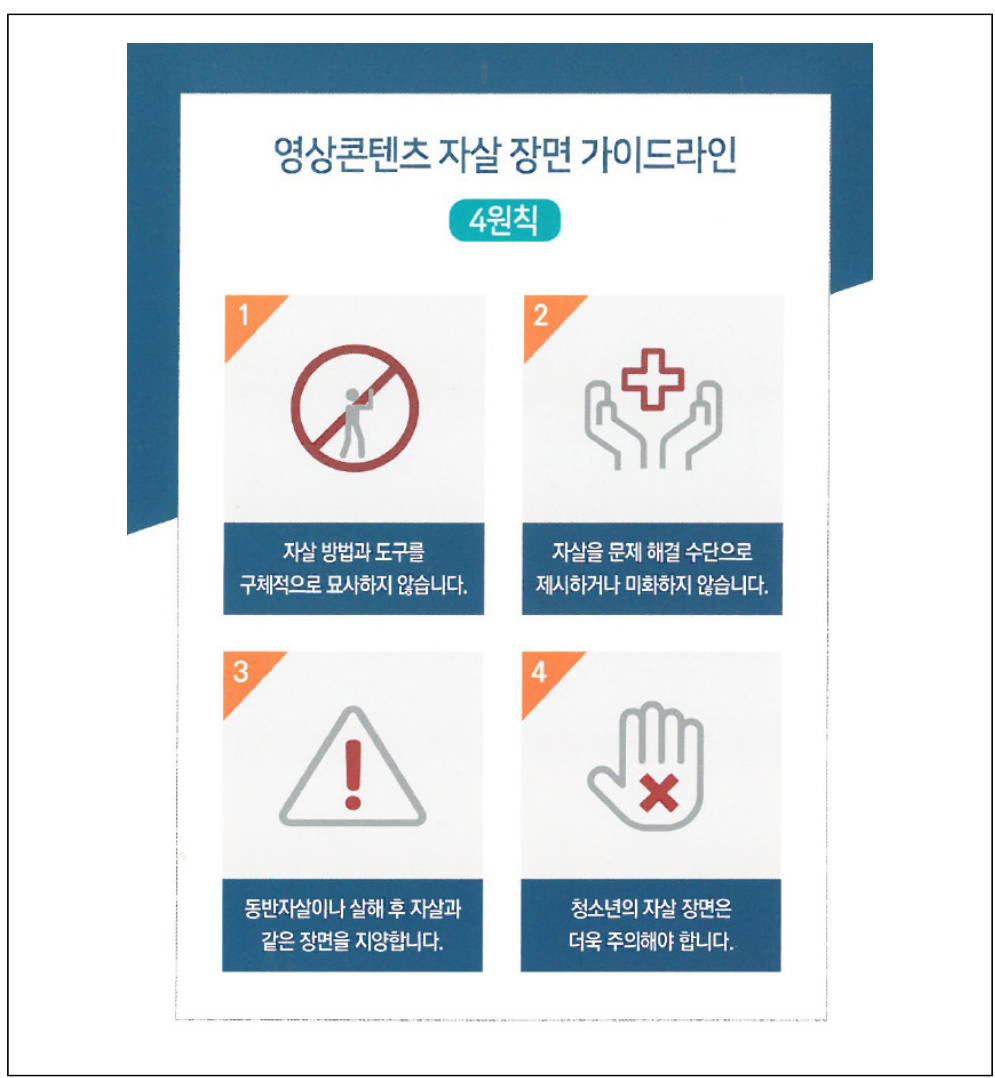

출처: 보건복지부 외(2019). 생명존중문화 확산을 위한 영상콘텐츠 자살 장면 가이드라인 


\section{3. 시사점}

- 대중문화예술인 주변인에 대한 게이트키퍼 교육 프로그램 적용 필요

- 대중문화예술인에 대한 직접적인 게이트키퍼 교육은 현실적으로 어려운 점이 많기 때문에, 매니저나 기획사 직원 등 이들 주변에서 활동하고 있는 문화산업 종사자들에 대한 게이트키퍼 교육을 활성화해야 할 것임

- 특화된 대중문화예술인용 게이트키퍼 교육 프로그램 개발 필요

- 자살예방 교육으로 가장 많이 사용되는 게이트키퍼 교육 프로그램이 집단 특성 에 맞게 개발될 때 교육의 효과가 높아지므로, 대중문화예술인을 대상으로 하는 별도의 게이트키퍼 교육 프로그램 개발이 필요함

- 자살보도기준 및 영상콘텐츠 가이드라인 준수 모니터링

- 자살보도는 유명 연예인이 대상이 되는 시례가 가장 많으며, 영상콘텐츠 자살 장면에 대한 가이드라인 역시 대중문화산업과 직결되는 영역이므로, 문화산업 내에서 보도 지침 및 가이드라인 준수 여부에 대한 지속적인 모니터링을 통해 정책의 효과성을 제고해야 함

- 뉴 미디어에 대한 자살보도기준 및 악플 대응책 필요

- 언론보도에 대한 자살보도기준을 마련하고 포털에서 연예뉴스에 대한 댓글을 차단했음에도 불구하고 SNS·유튜브-인스타그램 등을 통한 자살정보와 악플 유 통이 더욱 활성화되고 있어, 이를 방지하기 위한 보다 철저한 대응책이 필요할 것으로 보임 


\section{제3절 해외 자살예방 정책 사례}

일본과 핀란드는 우리나라보다 10여년 앞서 최악의 자살률을 경험한 국가임. 하지만 국가적으로 자살예방 에 대한 연구 수행, 정책 조직 확립, 다양한 자살예방 사업 전개 등을 통해 자살률을 획기적으로 낮추어 국제적인 모범사례로 인정받고 있음. 따라서 본 보고서에서는 우리나라 자살예방 정책의 벤치마킹 사례로 일본과 핀란드의 정책을 검토하였음

\section{1. 일본의 자살예방 대책}

- 일본의 자살 현황

- 일본은 1990년도 후반에 자살자 수가 급격히 증가하기 시작하여 1998년 3만 명 을 넘어 연간 3 만 2,863 명을 기록하였으며, 2003년에는 총 자살자 수 3 만 4,427 명, 인구 10 만 명당 자살 사망률 40.1 명으로 $\mathrm{OECD}$ 국가 중 1 위가 되었음

[그림 3-4] 일본의 자살자 수 추이

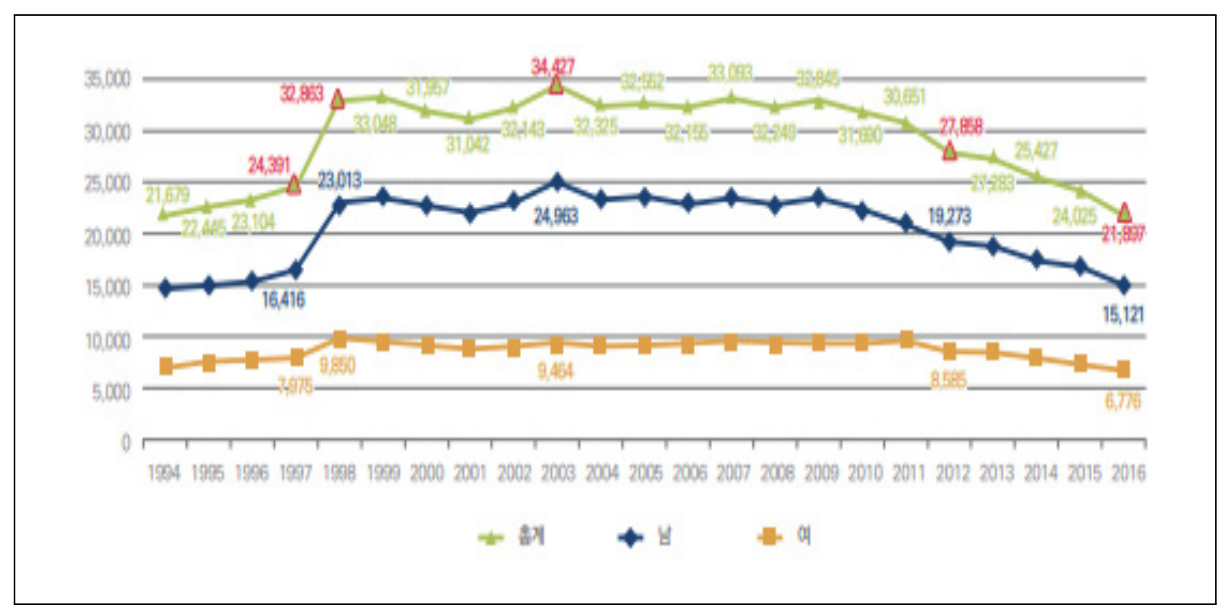

출처: 후생노동성,(2017). 일본자살대책백서 2017년 
- 1998년 이후 14 년 동안 연간 자살자 수는 3 만 명이 넘는 상태가 지속되었으나, 2012년 2만 7,858명으로 줄면서 3만 명 이하로 감소하기 시작하였음

- 이후에도 자살자 수는 계속 감소하여, 2016년 자살자 수는 2만 1,897명으로 22년 만에 처음으로 2만 2천 명 이하로 떨어짐

- 일본 자살예방 정책의 흐름

- 일본은 2006년 「자살예방기본법」을 제정하고, 2007년 내각부에 '자살대책추진 실'을, 국립정신신경센터 정신보건연구소에 '자살예방종합대책센터'를 설치하 고, 제 1 차 자살예방종합대책을 수립하였음

- 2009년에는 청년층에 대한 자살 대책, 지역 단위 자살 대책 등을 강화하였으며, '지역자살대책긴급강화기금'을 마련하여 사업을 시행함

- 2016년에는 「자살예방기본법」을 개정하면서 자살예방종합대책센터를 '자살종 합대책추진센터'로 개편·설립하고, 자살예방종합대책을 추진하는 소관 부처를 내각부에서 후생노동성으로 바꿈

- 2017년부터 제3차 자살예방종합대책을 수립하여 시행하고 있음

- 일본 자살예방 정책의 성공 요인

- 일본의 자살 정책의 성공은 자살문제에 대한 사회적 관심의 확대, 지역사회 중심 의 접근, 자살고위험군 관리 강화, 적극적인 예산 투입이 주요한 요인으로 꼽힘

- 일본의 자살예방대책은 중앙정부, 지방자치단체, 사업자뿐만 아니라 국민 개개 인에게도 자살예방 의무를 명시하고 있으며, 자살예방과 자살 유족에 대한 지원 을 충실히 수행하도록 규정하고 있음

- 중앙정부, 지방자치단체, 민간단체 간의 연계 체계를 강화하였으며, 지역 단위 의 중심의 적절한 지원 체계를 마련하여 실천적 자살예방대책을 추진하였고, 어 린이, 청소년, 노동자 등 집단별 자살에 대한 대책을 강화하였음

- 일본 자살예방관련 예산은 ' 13 년 2,873억 원에서 '14년 3,614억 원, '15년 7,837억 원, ' 16 년 7,927억 원으로 계속 증가하였음 


\section{2. 핀란드의 자살예방 대책}

- 핀란드의 자살 현황

- 세계에서 가장 오랜 기간 공식적인 국가 자살통계를 유지해온 국가인 핀란드는 1990 년 인구 10 만 명당 30.2 명을 기록하였으며, 특히 같은 해 남성의 자살률 은 50명을 넘어설 정도로 최악의 상황을 보였음

- 그러나 이러한 높은 자살률은 2011년 16.4명으로 급감하였으며, 특히 여성의 경우 1990년 12.3명에서 2005년 9.8명, 2011명 7.1명 까지 감소하였음

- 핀란드는 당시 자살률이 세계에서 가장 높은 나라 중 하나였는데, 이는 겨울에 해를 볼 수 없는 기후적인 요소와, 인구밀도가 낮아 인적 교류가 드물어 고립감 을 느끼기 쉽다는 것도 주요 요인으로 지적되었음

- 특히 산업화·도시화가 진행된 1965년 1990년까지 자살 사망률은 3배나 늘어, 기후와 인구적 요소뿐 아니라 산업화의 과정에서 사회적 요소들도 자살에 큰 영향을 미친 것으로 보임

[그림 3-5] 핀란드의 인구 10만 명당 자살사망률

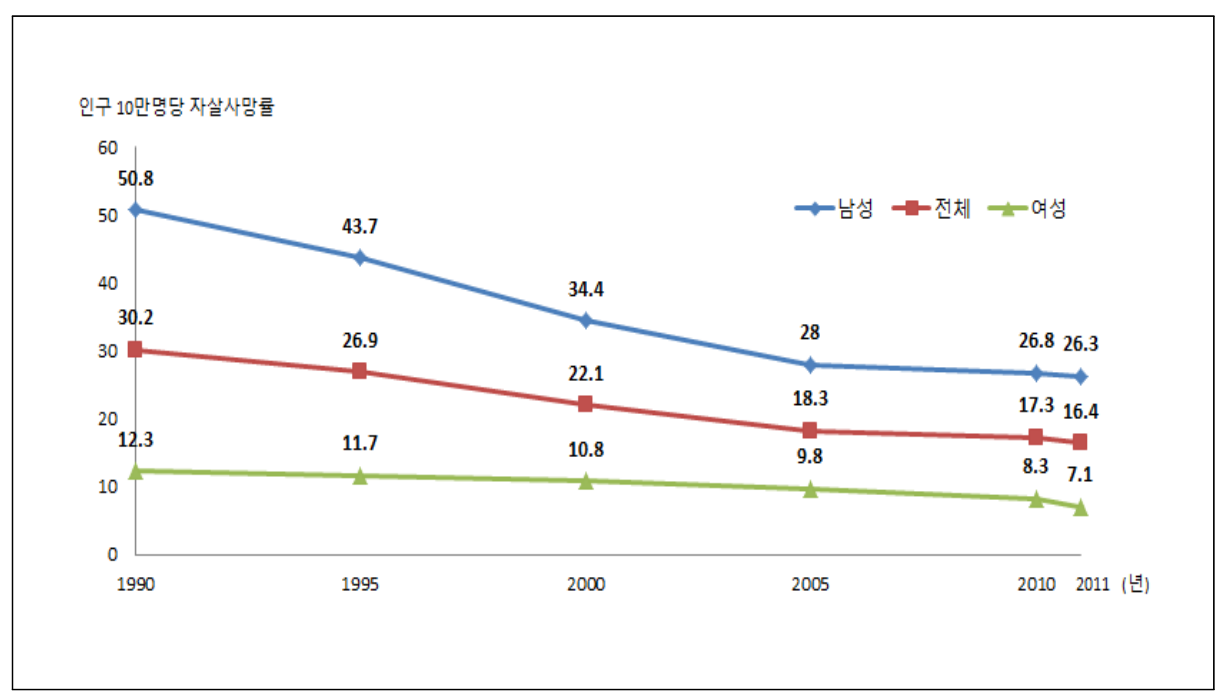

출처: OECD ilibrary(hoop://stats.oecd.org) 
- 핀란드의 자살예방 정책의 특성

- 1980년대 초 핀란드 보건복지부는 자살문제의 심각성을 인지하여 국가자살예 방프로젝트를 추진하기로 결정하고, 1986년 국가자살예방프로젝트를 공식적으 로 출범시킴

- 국가자살예방프로젝트의 첫 단계는 연구단계(1986 1991년)로, 핀란드공공보 건연구소(KTL)가 주도하였으며, 5년간의 연구 결과를 기반으로 국가 자살예방 목표와 실행 프로그램을 수립하였음

- 연구 과정에서 '87 '88년 사이 1년간 핀란드 자살사망자 1,366 명에 대한 전수 심리적 부검( Psychological Autopsy)을 실시하여 자살의 구체적 원인을 진단 하였음

- 프로젝트 2단계인 실행단계(1992 1996년)에서는 핀란드 보건복지연구개발센 터(STAKES) 주도로 자살예방 대책을 실행에 옮김

- 연구단계에서 형성된 네트워크 기반을 바탕으로 전문가 역량 개발, 전문가 훈련 및 평생교육 프로그램 실행, 안내 서적과 모범 사례집들을 제작하고, 대상에 따 른 맞춤형 프로그램을 운영함

- 또한 자살보도가 자살에 미치는 악영향과 자살을 막는 보호 효과를 파악하여, 유럽자살대응행동프로젝트 (EUREGENAS)를 통해 미디어 전문가들을 위한 권 고안과 자살예방 도구 모음을 제작·확산시킴으로써, 자살에 대한 보도의 방향 을 전환시킴

- 핀란드의 자살예방 정책의 시사점10)

- 핀란드는 심리적 부검 결과를 토대로 자살 원인을 유형별로 분류하고 각 유형에 따른 구체적이고 효과적인 대책과 권고안을 마련함으로써, 자살예방 정책을 성 공적으로 수립·추진한 국가로 인정받음

- 또한, 중앙정부, 지방자치단체, 학교, 산업장, 민간단체, 지역사회조직 등이 적 극적으로 자살대책에 참여하고, 전략 수립과 활동계획, 프로그램 실행, 평가 등 의 역할을 서로 분리하되 협력적이며 통합적으로 진행함으로써, 정책의 효율을 높였음

10) 국회예산처(2013). 「자살예방정책의 우선순위 및 추진방식 효율화 방안 조사」 


\section{3. 해외 자살예방 정책의 시사점}

- 연구를 기반으로 한 객관적인 자살 원인 파악

- 정책수립에 앞서 우선적으로 정신의학심리학 등의 연구를 통해 자살원인을 객 관적으로 파악하고, 연구 결과에 기반하여 구체적인 정책을 수립하였음

- 자살 원인에 따른 구체적이고 효과적인 대책과 권고안 마련

- 자살 원인별·집단별 세부적이고 구체적인 대책을 마련함으로써 자살정책의 효 과성을 제고함

- 중앙정부 및 지방자치단체, 민간단체와 역할 분리 및 협력적이고 통합적인 사업 시스템 구축

- 각 기관의 역할을 구분하되 상호 연계를 강화하는 통합적인 시스템을 구축하여 사업의 효율성을 높임

- 자살문제에 대한 사회적 관심 확대

- 자국에 만연하한 자살문제와 대응책에 대해 적극적인 홍보를 통하여 사회적인 관심을 불러일으키고 전 사회적인 대응이 가능하도록 하였음

- 자살예방 대책에 대한 적극적인 예산 투입

- 자살정책의 효과는 무엇보다도 계획된 사업을 실천할 수 있는 적극적 예산 투입 에 기반함 
대중문화예술인 자살문제 대응정책 연구

제4장

전문가 의견조사 



\section{제1절 조사 개요}

- 조사 목적

- 대중문화예술산업 현장에서의 자살 대응 정책 수요 파악

- 자살교육 및 자살대응정책 전문가들이 보는 대중문화예술계의 자살대응정책의 필요성과 세부 내용에 대한 자문

- 조사 대상: 총 17 명

\begin{tabular}{|c|c|c|}
\hline 구분 & 조사대상자 & 소속 및 직위 \\
\hline \multirow{6}{*}{ 대중문화산업계 } & 박 상 미 & 판타지오 R\&D센터 팀장 \\
\hline & 윤 선 재 & CNA에이전시 경영기획실 이사 \\
\hline & 서 일 식 & $\mathrm{CnH}$ 엔터테인먼트 신인개발본부 실장 \\
\hline & 이 자 연 & 대한가수협회 회장 \\
\hline & 남 진 & 前 대한가수협회 회장 \\
\hline & 전 유 림 & 대한가수협회 사무총장 \\
\hline \multirow{2}{*}{ 콘텐츠 관련 공공기관 } & 김 민 아 & 대중문화예술인지원센터 주임 \\
\hline & 장 광 진 & 대중문화예술인지원센터 차장 \\
\hline \multirow{5}{*}{$\begin{array}{l}\text { 자살예방 관련 } \\
\text { 단체 및 기관 }\end{array}$} & 권 순 정 & 공공기관 상담 교관 \\
\hline & 이 화 영 & $\begin{array}{l}\text { 한국자살예방협회 사무총장, } \\
\text { 순천향의대 교수 }\end{array}$ \\
\hline & 윤 진 & 중앙자살예방센터 총괄팀장 \\
\hline & 위 준 영 & 중앙자살예방센터 미디어대응팀 팀장 \\
\hline & 권 세원 & 중앙자살예방센터 연구개발팀 팀장 \\
\hline \multirow{4}{*}{ 학계 } & 윤 유 경 & 공군사관학교 심리학/상담 교수 \\
\hline & 정 정 숙 & 한국문화기획평가연구소 소장 \\
\hline & 장 규 수 & 한국연예산업연구소 대표 \\
\hline & 정 은 정 & 명지대학교 심리학과 교수 \\
\hline
\end{tabular}


- 조사 내용

〈전문가〉

- 근무하고 있는 곳에서 실행하는 자살예방 사업 소개

- 자살예방 교육 사업의 필요성과 효용

- 대중문화예술인 자살예방 교육의 필요성과 방향

〈산업 현장〉

- 산업 현장에서 느끼는 연습생-대중문화예술인들의 심리적 특성과 문제점

- 현장에서 느끼는 연습생·대중문화예술인들의 자살예방 교육 수요 및 필요성

- 산업 현장에서 교육의 효율을 제고할 수 있는 방안

- 조사 시기

- 2020년 5 7월 


\section{제2절 조사 결과}

\section{1. 정신의학 전문가(자살관련 기관, 정신과의사, 상담심리학자 등)}

- 기존의 자살예방 사업 현황

- 한국에서 자살예방 교육은 이제 어느 정도 체계가 잡혀있으며, 각 조직과 산업 체의 특성에 맞는 다양한 프로그램이 개발되어 실행 중에 있음

- 경찰청의 마음동행센터나 공군 등은 각 조직에 적합한 교육 프로그램을 개발하 여 시행 중에 있으며, 산업체의 경우 한국 $\mathrm{EAP}$ 에서 직장인들의 정신건강 프로 그램을 지원하고, 300 인 이상 기업체에는 상담실 설치를 권고하고 있음

- 한국의 자살예방 정책의 출발은 늦었지만, 최근 급속히 진화하여 해외 선진국들 에 비해 뒤지지 않는 시스템과 프로그램을 갖춰가고 있음

- 정부의 자살예방정책은 총리실이 중심이 되어 강력히 추진하고 있으며, 2021년 부터는 각 부처의 자살예방 사업을 부처 평가에 반영할 예정으로, 자살예방 정 책 추진에 대한 정부의 강력한 의지를 시시함

"지금 총리실에서 각 부처의 자살예방 사업을 강화하도록 요청하고 있고, 내년부터는 자살예방 정책이 각 부처의 평가에 포함되도록 하였습니다."

"현장에서 본 교육의 실효성을 이주 많이 느끼고 실감하고 있습니다. 공군은 프로그램 실행 이후, 전체 국가 자살율 증가와는 반대로 자살율이 감소하였습니다." "산업체 내에는 한국EAP가 있어 산업체 내애서 상담을 하기도 하고, 300 인 이상 기업 체에 대해서는 상담실 설치를 권고하고 있습니다."

"작년에 해외 선진사례를 살펴볼 수 있는 세미나가 열렸는데요, 그걸 본 후 우리끼리 ‘우리가 더 낫네'라고 애기했어요. 출발은 좀 늦었지만, 이제 우리 시스템도 많이 발전 했습니다." 
- 대중문화예술인에 대한 자살예방 교육의 필요성

- 자살관련 전문가들은 대중문화예술인의 개인적 문제가 아니라 연예인이 갖는 사회적 영향력에 대한 책임과 직업 윤리적 측면에서 자살예방에 대한 정책적 개입이 필요하다고 주장함

- 더욱이 연예인들은 직업적 특성으로 인해 외부 개입이 쉽지 않기 때문에 정부 차원에서 보다 적극적인 정책이 필요하다고 봄

"연예인의 자살은 베르테르의 효과가 크고 특히 청소년들에게 많은 영향을 미치기 때 문에 정부차원에서 보다 적극적으로 개입할 필요가 있습니다.”

"연예인의 자살은 사회적 파장이 매우 크므로 직업윤리 상 꼭 막아야 할 의무가 있습 니다.”

"대중문화예술인들에 대한 상담 사례에 의하면, 어릴 때부터 경쟁적인 연습생 생활을 했거나 야동기에 부모의 이혼, 가정불화, 주변인의 사망 등 상실을 경험한 경우가 그렁 지 않은 경우보다 우울하거나 적응상태가 좋지 못한 경향이 있으며, 이들은 스트레스 에 취약하므로 집중적인 관리가 필요합니다.”

"유명 연예인들에 대해서는 외부 개입이 매우 어렵습니다. 문제가 있어도 외부의 피드 백이나 실질적인 도움을 받기가 어려운 상황입니다.”

- 대중문화예술인 자살예방 교육 방안

- 최근 자살예방 교육이 발전하면서 타겟을 세분화하는 맞춤형 프로그램들이 증 가하고 있으며, 대중문화예술인의 경우에도 이들의 특성에 맞는 프로그램이 제 작될 경우 효과가 높을 것으로 예측됨

- 그러나 전문가들은 이미 스타가 된 연예인에 대한 직접적인 교육이나 개입은 어려울 것으로 예상하여, 연예인들과 자주 접촉하는 매니저 및 회사 직원들에 대한 교육으로 이를 대신하고, 연예인들에 대해서는 효율이 좀 낮더라도 온라인 교육 프로그램을 제공할 것을 제안함

- 연습생의 경우 연예인이 되기 전부터 미리 정기적으로 정신건강 교육과 자살예 방 교육을 제공한다면, 현재의 스트레스에 적응하고 미래 연예인 생활에서의 문 제를 예방하는 효과도 볼 수 있을 것으로 전망함

- 심리상담은 연예인 및 연습생들에게 심리적 안정 및 게이트키퍼 역할의 작동에 
기초적인 도움이 될 수 있어 적극적으로 장려됨

"연예인에 대한 직접적인 교육이 어려우면 연습생이나 매니저, 기획사 직원 등을 위한 교육 프로그램이 가능합니다. 연예인을 위해서는 효과성이 좀 떨어져도 온라인 버전이 가능할 겁니다."

"연습생들은 자살에 중점을 두기 보다는 진로교육과 함께 교육을 시키면 효과가 높을 겁니다. 이들은 자살보다는 현재 처한 상황에서의 스트레스가 높기 때문에 다양한 정 신건강 프로그램을 함께 진행하는 것이 좋습니다. 그리고 연습생 때부터 정신건강 교 육을 받으면 이후 자살예방 교육에 대해서도 거부감이 줄어들 거예요." "대중문화예술인 버전의 자살예방 교육 프로 그램은 좀 더 연예인의 특성에 맞도록 더 심화되고 특화될 필요가 있어요"

- 대중문화예술인 자살예방 교육 의무화에 대한 의견

- 활동 중인 연예인들을 대상으로 직접적인 교육은 현실적으로 어렵기 때문에, 연 습생과 기획사 직원에 대한 게이트키퍼 교육이 더 유용할 것으로 예측함

- 또한 대중문화예술인의 자살예방 교육이 실효성을 얻기 위해서는 모든 기획사 직원에 대한 의무교육으로 이루어져야 할 것임. 즉, 기획사 직원에 대해서는 교 육 의무화를 통해 강제해야만 실질적인 효과를 얻을 수 있을 것으로 예측됨

“교육은 최소 1년에 1회는 실시해야 하며, 의무교육이 되어야 합니다. 온라인 교육도 가능하지만, 자살예방교육은 현장성이 매우 중요하기 때문에 대면교육이 필요합니다." "가능하면 기획사의 모든 직원이 교육을 받을 수 있도록 강제할 수 있으면 좋겠습니다." "기획사에서 게이트키퍼 교육의 실효성이 나타나기 위해서는 매니저뿐 아니라 기획사 사장님 이하 모든 직원이 참여해야 하며, 특히 사장님의 솔선수범이 중요할 것입니다." "일정 규모 이상의 기획사는 상담실을 운영하도록 하며, 상담가는 어시스트 교육을 필 수로 이수하도록 해야 합니다. 이와 별도로 모든 직원은 자살예방 교육을 받도록 하여 연예인에 대한 사회적 안전망을 형성해야 합니다."

- 기존 자살예방 교육의 효과성 제고 방안

- 최근 국무총리가 직접 자살예방 교육을 받은 것이 각 부처의 자살예방 정책에 큰 영향을 미치고 있으며, 공군의 경우 매년 공군참모총장이 자살예방 교육을 받음으로써 자살예방 교육의 중요성과 가치를 리더가 직접 보여주고 있음 
- 또한 공군은 자살예방 교육을 미 이수하였을 경우, 성과상여금이나 승진에 불이 익이 있을 수 있도록 훈령에 명시를 해놓아 자살예방 교육 이수율을 높이고 있 어, 교육 실효성을 높이기 위한 강제조항의 필요성을 시사함

- 또한 실효성 있는 교육이 이루어지기 위해서 자살예방 교육을 기획사의 법정 의무교육으로 지정하고, 대형 기획사의 상담실 운영을 의무화 해야 함 “총리님이 자살예방 교육을 받으신 이후, 자살예방 교육에 많은 힘이 실리고 있습니다." "공군은 2011년부터 공군참모총장이 제일 먼저 교육을 받고, 산하 인력이 모두 교육 을 받도록 하였습니다. 윗사람이 모범을 보이니, 교육이 원활하게 잘 이루어지고 있습 니다. 문화체육관광부의 경우에도 장관님과 기획사 사장님들이 함께 제일 처음 교육을 받는다면 큰 효과가 있을 것입니다." “자실방지교육처럼 비자발적·저동기 프로 그램은 위에서부터 받아야 실효성이 있어요"

- 향후 자살예방 교육의 확대 방안

- 전문가들은 대중문화예술인의 자살예방 교육을 '자살'에 한정하지 말고 연예인 마음건강 전반에 대한 정책으로 확대할 것을 주장함

- 자살은 여러 가지 마음건강 문제의 최종 종결점이기 때문에, 정책적 역량을 최 종 지점에 집중하기 보다는 사전에 이를 방지하고 평상시 마음건강을 유지할 수 있도록 하는 정책이 더욱 효율적일 것이라는 의견임

- 평상시 상담이나 마음건강 프로그램 등은 미래의 자살을 예방하고 식별할 수 있는 실효성 있는 방안도 될 수 있기 때문에, 자살예방을 위한 정책은 자살예방 교육 이전에 마음건강에 대한 관심으로 확대되기를 희망하고 있음

"연예인의 자실방지 대응책은 좀 더 확대되어 연예인 정신건강 정책으로 나아가야 합 니다."

"연예인들의 직업적 특성상, 전문가에 의한 정기적인 상담은 심리적인 안정감이 상승 되며 의사소통 기회를 제공한다는 점에서 자살예방의 방법이 될 수 있고 이는 장기적 인 직업 유지에도 긍정적 효과가 있습니다. 그리고 정기적인 심리검사 같은 것은 자살 을 예방하고 식별하는 하나의 대안이 될 수 있습니다."

"연예인들의 심리적 서비스에 대한 요구는 증가하고 있지만, 기획사의 인식이 부족하 고, 비용적인 요인 때문에 이들에게 충분한 심리적 서비스 제공이 어렵습니다. 이를 정책적으로 지원을 한다면 효과적일 수 있습니다." 


\section{2. 문화산업 전문가(기획사 종사자, 콘텐츠 관련 기관 근무자 등)}

- 대중문화예술인들의 심리적 특성

- 특수한 직업 환경으로 인하여 인간관계는 매우 배타적이고 제한적이며, 이로 인 해 정신건강의 지지기반이 되는 인간관계가 부족할 수 있음

- 연예인들은 직업적 특성으로 인하여 작업시간이 매우 불안정하나 이를 스스로 콘트롤 하기 어려우며, 갑작스런 인기와 소득으로 인해 가족을 포함한 인간관계 에 변화가 발생하고, 인기 지속 여부에 대한 불안이 증가하는 등 심리적 문제를 겪는 경우가 많음

- 연습생의 경우 불확실한 미래에 대한 불안감과 어린 나이에 과도한 경쟁 상황에 놓이게 됨으로써 겪는 스트레스가 큼

- 즉, 상당히 많은 대중문화예술인들이 직업적 특수성으로 인해 정신건강을 유지 하기 매우 어려운 상황에 처해 있음

"연예인들은 일정한 스케줄이 아니라서 일이 몰릴 때 컨디션 조절을 잘 해야 해요 일 이 많을 때에는 잠도 부족한데, 화면에 최상의 컨디션의 모습을 보이게 하려면 수면 조절을 해야 합니다. 그래서 많은 연예인들이 수면제를 복용하고 있고 만연되어 있다 고 볼 수 있어요 수면제 복용이 지속되면 내성도 생기고, 우울증이나 조울증이 생기기 십죠"

"배우는 거의 대부분 수면장애 같은 문제가 있다고 보면 됩니다. 없는 연예인이 없을 정도예요. 아마 “스타 직업병'일 수도 있을 거 같아요."

"연예인들은 직업 특성상 접촉할 수 있는 주변 사람들이 제한적이고 인간관계가 배타 적이라 정신건강에 다양한 보호요인이 작동하기 어려워요. 공인 아닌 공인이기 때문에 치료도 적극적으로 받기 어렵구요."

"인기 스타가 되면 집에서 식구들과의 관계도 변해요. 집에서 부모들도 이들의 눈치를 보게 되요. 집에서 왕과 같은 지위를 갖지만, 그 이면에는 집안을 지탱해야 한다는 부 담을 동시에 느끼는 거예요."

"많은 돈을 벌어도 돈이 생김으로 인해 가족 간의 갈등도 많아집니다. 이로 인해 연예 인들은 집에서조차 보호받지 못한다는 생각을 많이 해요."

"연예인들은 대중들의 호감으로 자신들의 직업적 성취를 판단하기 때문에 독립적인 자 아 형성이 어렵습니다. 이들은 자신의 노력 이전에 타고난 재능이나 타인의 평가가 절 
대적이라는 점에서, 자신의 삶을 주도적으로 통제할 수 없다는 생각이 크고 이로 인해 자아존중감이 낮게 나타나는 경향이 있습니다."

“댓글은 눈에 띄기 때문에 타켓이 되었을 뿐, 댓글이 연예인 자살의 주요 원인이라고 보기는 힘들 거 같아요. 하지만 대중과의 소통에서 자신이 어떵게 보이는지에 대해서 는 매우 예민합니다. 남들의 시선으로 인해 항상 불편한 생활을 하게 되는 거고, 그러 한 불편이 조울증을 조장할 수 있을 거예요.”

"연습생들은 자유가 많이 없고 규제가 많은 상황에서, 친구들끼리 경쟁을 해야 하고, 자신의 실력에 좌절도 많이 느끼고, 데뷔를 할 수 있을지 미래에 대한 불안도 매우 높 아요. 건강했던 아이들도 힘들어 하고, 종종 과호흡이나 경련, 공황장애 같은 증상으로 나타나기도 합니다."

- 자살예방 교육에 대한 현장의 높은 수요

- 지원기관의 우려와는 달리 산업 현장에서는 실질적인 필요에 의해 교육 니즈와 수요는 매우 높은 것으로 나타남

- 연예인에 대한 직접적인 교육이 어려울 경우 연습생 및 직원 교육으로 자살예방 교육을 받고 싶어 함

- 직원 대상 자살예방 교육은 대중문화산업계 인력에 대한 역량강화 교육의 성격 도 있어 기획사 직원의 업무 교육으로 적합할 것으로 보이며, 연습생 대상 교육 역시 효과성이 높을 것으로 예상함

- 다만, 영세한 회사를 위해 출장 교육 서비스, 교육 프로그램 비용 등에 대한 지 원이 필요할 것으로 보임

“종현이 죽었을 때 이를 발견한 매니저나 샤이니 멤버들은 심리상담이나 자살예방 교 육을 받았을까요? 사실 현장에서 이런 교육의 필요성을 더 절실히 느끼고 있어요." "직원들의 교육 욕구나 수요는 많다고 봅니다. 직원 교육이라면 회사 대표들은 모두 찬성할 거 같아요. 직원 업무능력과 역량을 강화해주는 교육인데 왜 마다하겠어요? 기 업의 수준을 높여주는 건데요."

"기획사에서는 상담 프로그램에 대한 필요성을 절감하고 있습니다. 특히 1년 이상 된 연 습생들은 꼭 필요합니다. 상담비용 정도는 회사 내에서도 투자가치가 있다고 생각하고 있어요 회사마다 관리시스템이나 철학이 달라 좀 다르게 생각하는 경우도 있겠지만..." “SM이나 JYP 같이 큰 회사는 자체적으로 상담프로그램을 운용하고 있다고 들었습니 
다. 이것이 기획사에 상담이 필요하다는 반증 아니겠어요? 다만, 내부의 이야기가 밖 으로 흘러 나갈까봐 매우 조심스러워하죠."

"특히 아티스트와 마주치는 부서의 직원들이 필수로 들어야 합니다. 매니저, 신인개발 팀, 팬마케팅팀, 영상팀, $A \& R$ 팀 등 연습생이나 연예인들을 자주 마주하는 부서 직원 들은 의무적으로 들어야 하구요."

"상담이나 심리검사프로그램에 대한 연습생들의 니즈가 매우 높습니다. 원하는 수요자 는 많은데, 공급이 부족한 상황이죠."

"연습생 중에는 데뷔를 하지 못하거나, 중도에 포기하는 친구들이 많은데, 이들에 대 한 사회적응훈련이나 직업 전환 교육 등이 필요할 거 같아요 하지만, 영세한 기획사들 은 이를 수행할 능력이 없어요."

- 대중문화예술인지원센터의 역할과 한계

- 한국콘텐츠진흥원에서 운영하는 대중문화예술인지원센터가 운영하는 상담 프로 그램을 적극 활용하고 있는 기획사가 있는 반면 전혀 인지하지 못하고 있는 기 획사도 있음

- 센터 프로그램을 이용해 본 경험이 있는 경우, 실질적인 효과를 높이기 위해서 는 상담 횟수를 늘리고 다양한 심리검사를 활용할 것을 요구하였음

- 대중문화예술인지원센터를 인지하지 못한 경우, 상담 및 심리검사 프로그램에 대한 정보 입수가 가능하도록 적극적인 홍보를 요구함

- 이용 경험자나 비 경험자 모두 비용이 무료라는 것을 큰 장점으로 꼽았음 "콘텐츠진흥원의 상담센터를 이용하기도 하는데, 무료이기 때문에 접근이 용이합니다. 심리검사는 애들이 호기심도 많고 관심도 많아서 다 하고 싶어 하구요. 하지만, 진짜 상담을 받기에는 너무 횟수가 적어요.”

"대중문화예술인지원센터에 대해서는 한 번도 들어본 적이 없어요. 어떤 서비스가 있 는지도 모르구요."

"연예인들이 십게 상담 받을 수 있는 환경을 만드는 것이 중요할 거 같아요."

- 교육 의무화에 대한 요구

- 정책 담당자나 관련 기관에서는 자살예방이나 정신건강 프로그램을 기획사의 의 무교육으로 정하는 것에 부정적인 견해를 보이기도 했으나, 기획사 등 산업 현장 
전문가들은 '직원 의무교육'이 되어야만 교육의 실효성이 있을 것임을 강조함

- 업체의 1 인으로 되어 있는 현재의 대중문화예술기획업자 법정교육은 회사의 '아무나 1 인'이 교육을 받아도 되는 상황이라, 교육의 실질적인 효과가 나타나 기 어려움

- 자살예방 교육이 효과를 얻기 위해서는 업계 인력 모두, 혹은 최소한 회사 대표 와 경영자, 연예인을 직접 대면하는 시간이 많은 직원들에게는 '의무 교육' 으로 강제해야할 것으로 보임

- 자살예방 교육은 기획사 내 연예인과 연습생에게 발생할 수 있는 문제를 사전에 방지하고 실질적인 도움을 줄 수 있는 것이기 때문에 직원들의 업무능력 향상에 필요한 교육으로 인식하고 있으며, 실효성 있는 업무교육 프로그램이 될 수 있 을 것으로 기대하고 있어, 기획사에서 '의무 교육’에 대한 부담감이 크지 않을 수 있음

"연예기획사에 특벌히 매니저라는 직함으로 직원이 등록되어 있지 않아요. 그냥 일반 직원으로 등록되어 있지요. 콘텐츠진흥원에서 하는 매니저 교육은 회사에서 1년에 1 회 1 인이 의무적으로 받아야 하는데, 보동은 회사에서 가장 한가한 직원이 가요. 연습 생이나 연예인은 사실상 회사의 직원이 아니구요."

"콘텐츠진흥원에서 진행하는 프로 그램이 있기는 하지만, 법인의 경우 1년에 한명만 가 서 3시간 정도 교육을 받으면 그만이예요 대형기획사는 직원이 많아서 1 명이 가서 교육을 받는 다는 것은 형식적인 것에 불과하고 효과도 없어요." "기획사에서 게이트키퍼 교육의 실효성이 나타나기 위해서는 매니저뿐 아니라 모든 직 원이 참여해야 합니다."

"자살예방교육은 규모에 상관없이 모든 기획사가 다 의무적으로 받으면 좋겠어요. 연 예인은 교육을 강제하기 매우 어렵지만, 연습생들은 다 받을 수 있을 거예요."

- 리더의 솔선수범

- 자살예방 프로그램을 대중문화산업계에 효과적으로 확산시키기 위해서 기업 대 표나 문화체육부 장관 등이 자살예방 교육에 솔선수범해야 함

- 정책 및 업계 리더들이 자살예방 교육에 관심을 갖는 모습은 교육에 대한 인식 을 제고하고 긍정적인 여론을 형성하여 교육의 실효성을 높일 것으로 기대됨 
"자살방지 교육이 실효성을 얻기 위해서는 리더십이 필요합니다. 문체부 장관님, 기획 사 사장님, 유명 연예인이 솔선수범하여 교육을 이수하면 그 영향력이 매우 크게 나타 날 거 같아요."

"문체부 장관님과 SM, JYP 같은 회사 대표가 교육에 참여한다면 나머지 기획사들은 거의 모두 교육을 받을 겁니다. 그리고 그런 회사들이 들어온다면 연예인 홍보대사도 섭외가 가능할거구요."

“큰 기획사는 직원이 많지만, 한 두 명만 듣지 말고 가능하면 많이 들었으면 좋겠어요. 특히 윗분들일수록 경영차원에서 꼭 들어야 할 거 같아요."

- 자살예방 교육에서 대중문화예술인 정신건강 교육으로

- 산업 현장에서는 자살예방 교육보다 이를 포함하는 더 넓은 의미의 대중문화예 술인 정신건강 교육이 필요함을 호소함

- 대중문화예술인들이 심리적 특성과 직업적 환경에서 받는 스트레스에 대응하기 위해서는 자살예방 교육 이전에 그들의 심리적인 지원 및 마음건강에 대한 프로 그램이 우선되어야 함

- 현재 대중문화예술인지원센터에서 진행하는 상담 프로그램은 횟수와 내용에 한 계가 있음에도 불구하고 그 수요는 계속 증가하고 있어, 대중문화예술계의 정신 건강 교육이나 프로그램에 대한 수요는 매우 높음을 알 수 있음

- 특히, 업계에서 신뢰가 높은 상담자에 대한 수요는 비용을 지불하고서라도 의뢰 를 요청하는 경우가 늘고 있어, 상담 및 정신건강에 대한 업계의 필요성을 확인 할 수 있음

“설리나 구하라의 자살은 악플이 직접적인 원인이라고 생각하지 않아요. 근본 원인은 따로 있다고 봅니다. 언론이 원인을 호도시키고 있는 거고, 핵심 문제를 회피하는 거예 요. 이런 문제에 대응하기 위해서는 전문가가 필요하다고 봅니다." "자살보다는 정신건강 측면에서 접근하고, 정신건강 교육 프로그램을 보급한다면 더 좋을 거 같아요. 자살이 일어나기 전에 스트레스를 줄이고 적응할 수 있도록 도와주어 야 자살이 발생하지 않죠."

“자살예방 교육이라는 제목 자체가 부담스러워요. '자살'이라는 단어가 부정적인 인식 을 심어주기 때문이죠 같은 교육을 실시하더라도 자살예방 교육이라는 타이틀 보다는 정신건강이라는 긍정적인 타이틀이 더 좋겠어요." 


\section{3. 시사점}

- '마음건강'에 취약한 대중문화예술인의 직업적·심리적 특수성

- 대중문화예술인들의 특수한 직업 환경은 심리적인 불안과 스트레스를 높이며 자아존중감에 부정적 영향을 미칠 수 있음

- 연습생의 경우 어린 나이에 업계에 입문하여 과도한 경쟁과 불확실한 미래로 인해 심리적 불안이 높고, 학교생활을 충실히 하지 못해 사회적 지지를 얻을 수 있는 관계 형성의 기회나 스트레스 적응 훈련이 부족할 수 있음

- 인기와 큰 수익을 얻은 후에도 가족관계나 업계 내 인간관계에 많은 변화와 갈 등이 발생하고, 사생활이 대중들에게 노출되면서 심리적 불안과 스트레스가 가 중될 수 있음

- 산업현장에서 느끼는 자살예방 교육 및 마음건강 교육의 필요성

- 자살은 마음건강에 문제가 발생했을 시 나타나는 최종적인 결과이기 때문에 자 살예방 프로그램에 앞서 대중문화예술인의 스트레스 적응 및 심리적 안정을 돕 는 마음건강 지원 프로그램이 선행되어야 할 것임

- 산업 현장에서도 연습생 및 연예인들의 마음건강 교육의 필요성은 커지고 있으 며, 자살예방 교육은 연예인들과 함께 하는 기획사 직원들에게 업무능력 제고를 위한 직업교육으로서의 가치도 지님

- 자살예방 교육 프로그램의 실효성 제고를 위한 방안

- 대중문화예술인 자살예방 교육의 효과를 높이기 위해서는 이들에게 특화된 게이 트키퍼 프로그램이 필요하며, 따라서 연예인들이 겪는 특수한 직업적·심리적 문 제 시례들을 담은 대중문화예술인용 게이트키퍼 교육 프로그램 개발이 시급함

- 문화부 장관, 대형 기획사 대표 및 유명 연예인들이 함께 교육을 받는 모습을 공개함으로써 연예인 자살예방교육을 널리 홍보하고 교육의 실효성을 높일 수 있을 것임

- 자살예방교육이 형식적인 교육에 그치지 않도록 하기 위해서는 기획사의 모든 직원, 혹은 최소한 연예인과 접촉이 높은 업무를 수행하는 직원에 대해 자살예 방교육을 의무교육으로 지정해야 함 
대중문화예술인 자살문제 대응정책 연구

\section{제5장}

정책 제안 



\section{제1절 대중문화예술인 자살문제 대응정책의 필요성}

[그림 5-1] 대중문화예술인 자살 원인과 해결 방안

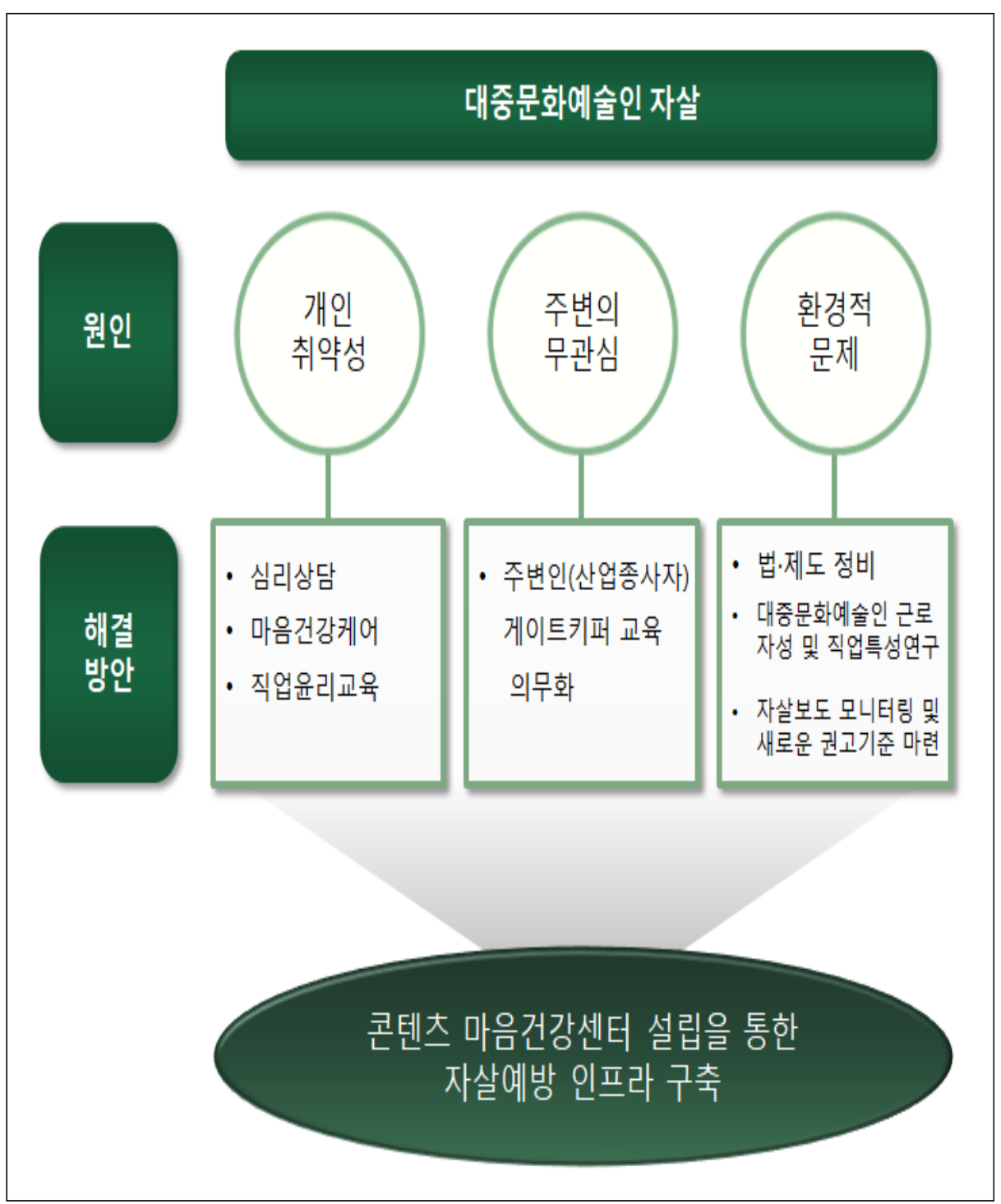




\section{1. 대중문화예술인 자살 취약성 및 영향}

- 직업인으로서의 대중문화예술인 자살의 취약성

- 대중문화예술인은 정서적 편차가 심한 감정노동에 종사함으로 인해 일반인에 비해 정신건강 문제에 쉽게 노출될 수 있으며, 사회적 지지기반의 약화, 사생활 노출, 인터넷 악플, 치료에 나서기 어려운 환경 등으로 문제가 해결되지 않고 축적되어 자살이라는 극단적 행동으로 이어지는 경향이 있음

- 인기하락의 부담감, 고용불안정으로 인한 직무불안정, 활동 시기에 집중되는 노 동 강도 등 대중문화예술인의 직업적 특성 또한 이들의 스트레스를 높이고 정신 건강에 부정적 영향을 미침

- 대중문화예술인 자살이 한류에 미치는 영향

- 대중문화예술인은 한류를 기반으로 전 세계로 확대되고 있는 우리 문화산업의 핵심이자 주요 자산으로서, 이들의 자살은 대중문화산업뿐 아니라 한국의 이미 지나 국가브랜드에도 부정적 영향을 미칠 수 있음

- 우리나라 기획사 시스템에 대해 비판적 시각을 가진 해외 언론들은 기획사들이 어린 대중문화예술인들의 인권을 침해하고 과도한 관리·감독을 하고 있으며 이 들의 정신건강에 대해 무관심하다고 지적하고 있고, 아이돌 스타가 자살할 때마 다 우리나라 기획사 시스템의 문제점을 부각시키고 있음

- 대중문화예술인 자살이 일반인에게 미치는 영향

- 대중문화예술인의 자살은 일반인들의 자살을 촉발시키거나 자살방법을 모방하 도록 하는 '베르테르' 효과가 있으며, 특히 이를 따르는 청소년과 팬들에게 악영 향을 미치고 있음 


\section{2. 대중문화예술인 자살문제 대응을 위한 저변 확대 필요}

- 대중문화예술인 자살 방지에 도움을 줄 수 있는 사람들

- 대중문화예술인의 정신건강 문제는 직접적인 개입이 어려운 경우가 많아, 자살 방지 대책 역시 직접적인 방안보다는 이들을 도외줄 수 있는 주변인을 확대하는 방안이 더 효율적임

- 대중문화예술인들과 함께 생활하는 매니저는 물론 기획사 대표와 직원들이 그 대상이 되며, 이러한 주변인들이 대중문화예술인의 정신건강 문제나 자살 시도 에 미리 대처할 수 있는 게이트키퍼 역할을 할 때 자살방지에 큰 효과가 있음

\section{3. 대중문화예술인 노동환경 개선 필요}

- 대중문화예술인 노동환경의 문제

- 대중문화예술인의 노동은 비정규직 성격이 강하고, 노동의 수요-공급 정보가 불 명확하여 직무불안정성이 매우 높으며, 개인 사생활이 쉽게 노출되고 악플로 인 하여 고통 받기 쉬운, 일반 노동환경과 구분되는 특성을 갖고 있음

- 기획사 중심의 대중문화산업 시스템에서 청소년 혹은 젊은 연예인들은 과도한 경쟁과 정서적 어려움, 학업 중단의 가능성이 높으며, 인권 침해를 당하는 사건 사고도 끊임없이 발생하고 있으나, 연예인의 노동성과 노동환경에 대한 연구와 대응책은 미미함

- '예술인'과 구분되는 대중문화예술인 정책

- 대중문화예술인은 노동자 또는 예술인, 그 어느 쪽에서도 정체성을 확실히 보장 받지 못하고 있으며, 이로 인해 노동자 정책이나 예술인 정책 모두에서 열외 혹 은 소홀하게 취급되고 있음

- 한국예술인복지재단의 예술인 지원 프로그램의 대상에 대중문화예술인이 포함 되어 있으나, 실제로 대중문화예술인의 이 혜택을 받는 것은 거의 불가능한 것 으로 알려져 있으며, 대중문화예술인들 스스로 정책 대상이 되고 있음을 인지하 지 못하는 경우가 많아, 대중문화예술인에게는 유명무실한 정책이 되고 있음 


\section{제2절 대중문화예술인 자살문제 대응정책}

\section{1. 대중문화예술인 개인 취약성 지원 방안}

- 대중문화예술인 자살방지를 위한 1 차적 지원

- 많은 전문가들이 자살은 스트레스와 정신건강에 문제가 있을 때 나타나는 최종 결과물일 수 있다고 애기하고 있어, 대중문화예술인의 자살예방을 위해서는 1 차적으로 이들이 격고 있는 감정적심리적 문제를 쉽게 털어놓고 상담할 수 있 는 방법과 기회를 확대해야 함

- 대중문화예술인이 겪는 특수한 상황을 잘 이해하고 개인 정보의 외부 누출에 대한 염려가 없는 신뢰로운 상담자를 확보해야 하며, 상담에서 문제를 털어놓고 자연스럽게 종결될 수 있도록 충분한 횟수의 상담 횟수를 제공해야 함

- 대중문화예술인지원센터의 대중문화예술인 심리상담 확대

- 현재 한국콘텐츠진흥원 내에 대중문화예술인의 법률·심리 상담을 전담하는 기 관인 대중문화예술인지원센터가 설치·운영되고 있으며, 연습생을 대상으로 하 는 상담 프로그램은 이용자의 만족도도 높게 나타나고 있음

- 하지만, 대중문화예술인지원센터를 인지하고 있는 대중문화예술인이나 기획사 직원은 소수에 불과하고 이용자의 범위는 연습생이며 상담의 횟수는 심리검사 포함 3회로 제한되어, 대중문화예술인을 위한 충분한 지원이 이루어지지 못하 고 있음

- 보건복지부에서 운영하는 중앙자살예방센터 및 지역자살예방센터는 아직까지 대중문화예술인을 대상으로 하는 별도의 프로그램이 없으며, 한국예술인복지재 단의 상담 프로그램의 경우 대중문화예술인이 지원 대상에 포함되어 있으나 실 질적으로 지원을 받기는 매우 어려운 상황임 
- 또한 대중의 노출을 꺼려하는 연예인의 특성상 산업계 밖 외부의 일반 상담기관 이나 정신과를 이용하는 데에도 많은 부담을 느낌

- 따라서 현재 운영 중인 대중문화예술인지원센터의 대중문화예술인 심리상담 프 로그램의 횟수를 늘리고 대상을 확대함으로써, 대중문화예술인의 심리적 문제 에 사전 대응하여 자살을 예방할 수 있는 시스템을 구축해야 함

- 상담, 정신건강 프로그램, 예산 확대

- 대중문화예술인지원센터가 대중문화예술인 정신건강을 위한 전문 기관으로 발 전하기 위해서는 현재 진행 중인 상담 프로그램의 양적인 확대와 질적인 제고 방안이 전제되어야 함

- 또한, 향후 추진될 대중문화예술계의 자살예방 교육의 의무화에 대비하여 전문 인력 배치와 예산 확대가 뒷받침 되어야 할 것임

\section{2. 대중문화예술인 자살예방을 위한 저변 확대}

- 대중문화예술계 게이트키퍼 양성

- 활동 중인 연예인에 대한 직접적인 자살예방 교육이 거의 불가능한 상황에서 이들의 자살을 예방하기 위해서는 주변인에 대한 자살예방 교육이 필수적임

- 대중문화예술계 게이트키퍼 양성을 위해 대중문화예술인지원센터에서 게이트키 퍼 교육 프로그램을 확대 편성하고, 보다 많은 대중문화산업계 종사자들이 교육 을 받도록 해야 함

- 특히 연예인과 함께 일을 하는 매니저 및 기획사 대표, 직원들이 손쉽게 교육을 받을 수 있도록 지원해야 할 것임

- 대중문화예술인 버전 게이트키퍼 교육 프로그램 개발

- 연예인 대상 자살예방 교육 활성화와 효과성 제고를 위해서는 대중문화예술인 버전의 게이트키퍼 프로그램 개발이 전제되어야 함

- 일반용 게이트키퍼 프로그램은 노인용, 청소년용 등 세부 교육 대상에 따라 각 각의 버전으로 재 제작되고 있으며, 이를 통해 타켓 집단에 대한 교육의 효과를 제고하고 있음 
- 대중문화예술인의 직업활동의 특수성과 사회적 영향력 등을 고려할 때, 대중문 화예술인에게 특화된 별도의 프로그램 제작이 필요할 것으로 보임

- 대중문화예술인 버전 게이트키퍼 교육 프로그램 개발 개요

- 연예인 버전 게이트키퍼 프로그램 개발에는 온라인 버전 포함, 약 1 억 5천만 원 2억 원 정도의 예산과 1 년 정도의 개발 기간이 소요될 것으로 보임(한국자 살예방협회, 중앙자살예방센터 전문가 의견)

- 2021년 프로그램 개발에 돌입하기 위해서는 2021년 예산 수립 과정에 논의 되 어 예산을 확보하고, 2021년 예산 확정 후, 한국문화관광연구원이나 콘텐츠 진 흥원을 통하여 게이트키퍼 프로그램 개발 전문가 집단과 함께 개발 사업을 추진 토록 함

- 자살예방 교육 활성화 방안

- 매년 자살예방 교육을 받은 대중문화산업계 인력들에게는 교육 이수증을 수여 하고, 기업체 직원 모두가 자살예방교육을 이수했을 경우에는 '자살예방 교육우 수 기업'으로 표창을 하여 업계의 적극적인 참여를 유도함

- 반면, 교육 이수률이 낮은 기업에 대해 각종 지원정책에 제제를 가할 수 있는 방안을 모색하고 적용할 것을 권고함

- 대중문화예술인 자살예방 교육 인식 개선 및 홍보 방안

- 자살예방 교육 프로그램이 대중문화산업계에서 널리 활용되고 확산되기 위해서 는 산업계 내에서 자살예방 교육 필요성에 대한 공감대를 형성하고 교육 프로그 램에 쉽게 접근할 수 있도록 해야 함

- 2019년 이낙연 총리가 자살예방 교육을 받은 것이 언론에 공개된 후 자살예방 교육에 대한 정부와 사회의 관심이 제고된 것을 벤치마킹 하여, 대중문화산업계 에서도 문화체육부 장관을 비롯하여 대형 엔터테인먼트 기획사 대표, 유명 연예 인 등이 솔선수범하여 자살예방교육을 받도록 함

- 또한 유명 연예인을 대중문화예술인 자살예방 홍보 대사로 위촉하여 직접 교육 을 받고 교육의 필요성을 언론에 전파함으로써, 게이트키퍼 교육에 대한 사회적 인 관심을 불러일으키고 자살예방에 대한 대국민 인식을 제고함 
[그림 5-2] 2019년 국무총리 및 정부서울청사 직원 대상 자살예방 생명지킴이 교육

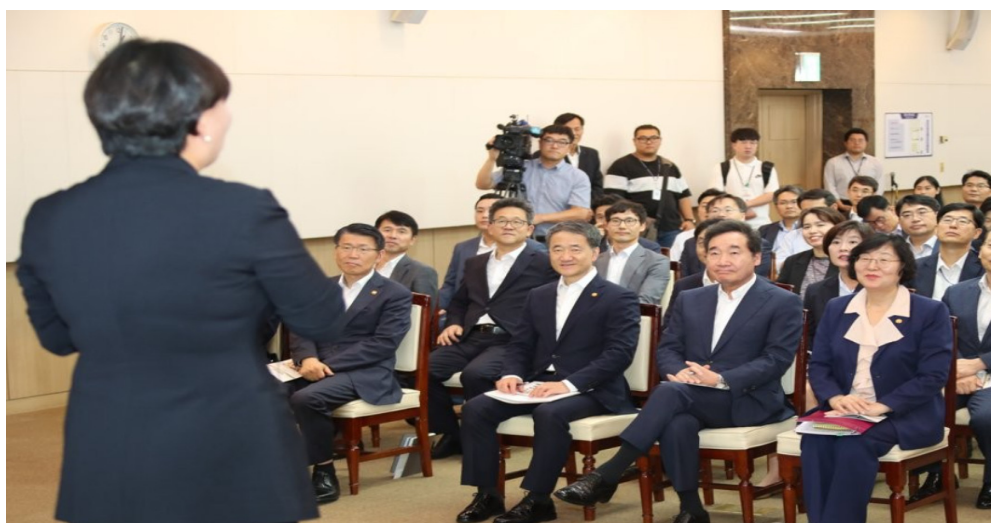

\section{3. 대중문화예술인 자살예방을 위한 관련 환경 개선}

- 자살예방을 위한 환경 개선 방안

- 대중문화예술인 자살예방의 효율성을 높이기 위해서는 직접적인 교육 프로그램 수행과 더불어 이를 둘러싸고 있는 각종 환경에 대한 개선 작업도 병행되어야 함

- 대중문화예술인 자살예방 교육 의무화, 자살보도에 대한 모니터링과 새로운 환 경에 적합한 자살보도 권고기준 마련, 대중문화예술인 근로자성에 대한 연구 및 관련 제도 보완 등이 포함됨

- 자살예방 교육의 의무화를 위한 법 개정

- 각종 활성화 방안도 대중문화예술산업 현장에서 자살예방 교육이 효과적으로 실시되기 위해서는 대중문화예술계 게이트키퍼 교육 의무화가 전제되어야 함

- 연예인에 대한 의무교육은 불가능하지만, 대중문화예술 기획업 종사자들에 대 해 의무교육화하는 것은 법 개정을 통하여 가능할 것임

- 자살예방 교육의 의무화를 위한 법 개정 방안

- 대중문화예술산업발전법 제17조(지원센터) (2) 지원센터의 업무 4에 "자살예방 을 위한 교육 지원"을 추가함

- 대중문화예술산업발전법 제29조 (5)에 "대중문화예술기획업자는 소속 연예인 및 연습생, 직원의 자살을 예방하고 정신건강에 대한 교육을 받아야 함”을 신설함 
- 자살보도 모니터링 및 새로운 권고기준 마련

- 2018년 자살보도 권고기준 3.0이 발표되어 실행 중에 있으나, 이는 '권고기준' 이며 불이행에 대한 처벌이 없어 강제 이행은 어려우며, SNS, 유튜브, 인스타그 램 등 다양한 뉴미디어에 대한 적용도 어려움

- 따라서 자살보도에 대한 모니터링을 통하여 문제가 되는 사항을 직접 찾아 대응 하고, 뉴 미디어에 적용 가능한 확대된 자살보도 권고기준을 마련해야 할 것임

- 대중문화예술인의 노동자성에 관한 연구 및 제도 마련

- 대중문화예술인의 정책에 있어 그 대상이 되는 대중문화예술인의 정체성이 '예 술인'과 '근로자' 사이에서 혼란이 있으며, 그로 인해 정책에 대중문화예술인의 특성이 반영되거나 고려되지 않는 경우가 많음

- 따라서 대중문화예술인의 직업적 특성에 따른 그들의 정신건강 문제들을 연구 하고 분석하여 실질적으로 피드백을 줄 수 있는 제도 및 체계가 마련되어야 대 중문화예술인 자살문제에 대한 근본적인 접근이 가능할 것임

\section{4. 대중문화예술인 자살예방 대응 콘트롤 타워 건립}

- 대중문화예술인 자살예방 관련 콘트롤 타워 필요성

- 대중문화예술인의 자살은 그 영향력이 산업영역에 한정되는 것이 아니라 대중 문화를 좋아하는 아동·청소년 및 성인 팬들에게까지 미치며, 국가 이미지에도 부정적 영향을 주므로 전 사회적으로 관심을 기울여야 하는 문제임

- 자살은 하나의 사건이라기보다는 기초적인 정신건강의 문제에서부터 비롯되어 발전된 최종 결과물이기 때문에, 자살예방을 위해서는 정신건강의 통합적 측면 에서 접근해야 하며, 대중문화예술인 뿐 아니라 이들과 상호작용하는 문화산업 관계자들과 문제를 공유해야만 자살예방의 실효성을 높일 수 있음

- 즉, 대중문화예술가의 자살예방을 위해서는 개인적인 정신건강을 위한 심리상 담, 주변인 게이트키퍼 양성, 관련 법제도 개선, 대중문화예술산업 노동 환경 개선 등 다양한 측면에서 접근해야 하며, 정신건강에 대한 저변확대나 인프라 구축 없이 자살만을 예방하는 프로그램은 일시적인 효과는 있을 수 있으나 근본 
적인 문제해결이 되지 못함

- 현재 운영 중인 콘텐츠진흥원의 대중문화예술인지원센터의 경우는 진흥업무를 담당하던 직원들이 관련 업무를 하고 있다는 점에서 정신건강 문제를 다루는데 한계가 있어, 대중문화예술인 정신건강 문제의 체계적인 접근을 위해서는 전담 전문 조직의 설립이 필요함

- 따라서 대중문화예술인의 정신건강 및 자살예방과 관련된 다차원적인 문제와 사업들을 통합적이고 일관성 있게 운용하기 위한 전문적인 콘트롤 타워인 '콘텐 츠 마음건강센터(가칭)' 설립을 제안함

- '콘텐츠 마음건강센터(가칭)' 설립은 정신건강에 대한 대중문화예술인의 정신건 강에 대한 관심과 인식을 제고할 뿐 아니라 우리 사회 전반의 정신건강에 대한 관심을 높이게 함

- 대중문화예술인의 정신건강에 관한 이슈는 아동, 청소년 뿐 아니라 일반 대중들 에게도 모델링 효과가 있다는 점에서 국가적인 정신건강에 대한 프레이밍을 가 능하게 함

- 콘텐츠 마음건강센터의 대상

- 콘텐츠 마음건강 센터는 대중문화예술인뿐 아니라, 예비대중문화예술인(지망생, 연습생) 및 산업 종사자를 모두 포함함

- 인간발달의 특성상, 대중문화예술인의 정신건강을 현재의 시점에서만 관리한다 는 것은 근본적인 해결책이 아니므로 대중문화예술인을 준비하는 연습생이나 지망생부터 프로그램을 제공하고 중요성을 부각해야 함

- 연습생 및 지망생 등을 포함한 프로그램 대상자 확대는 장기적으로 대중문화예 술인들이 스트레스에 대처하고 문제를 해결하며 정신건강에 대한 셀프 모니터 링 능력을 증대시킴

- 또한 산업계 종사자를 모두 포함하는 것은, 연예인에 대한 직접적인 교육이 불 가능할 경우가 많기 때문에 주변인 교육을 통해 연예인의 자살예방 및 정신건강 에 간접적인 도움을 주기 위함임

- 콘텐츠 마음건강센터의 프로그램

- '콘텐츠 마음건강센터(가칭)'의 프로그램은 대중문화예술인 심리 지원 프로그램 
과 자살예방교육, 진로 및 직업교육 등을 근간으로 구성함

- 심리 지원인 상담 프로그램은 대중문화예술인과 문화산업 종사자를 대상으로 개인상담 뿐 아니라 집단상담을 포함하는데, 집단상담은 그룹생활을 하는 연예 인의 경우 팀워크를 향상시키거나 갈등해결에 도움을 주는 프로그램이 제공되 며, 직원들의 경우 동료상담 프로그램 등을 통해 자신의 정신건강뿐 아니라 연 예인과의 소통 방법에도 도움을 줄 것임

- 대중문화예술인들이 갖는 직업적 특성으로 인해 개인상담이 용이하지 못할 경 우, 대안으로 온라인 상담과 심리검사를 제안함

- 온라인 상담은 직접 대면을 꺼려하고 기관 방문으로 신분이 노출되는 것을 염려 하는 연예인들에게 상담의 장벽을 낮출 수 있음

- 심리검사는 직접 대면하지 않아도 되기 때문에 대중문화예술인들의 정신건강 진단에 용이하며 상담이 필요한 대상을 선별할 수 있다는 장점이 있음. 기획사 등 조직적으로 다수의 요청이 있는 경우, 짧은 시간에 단체 심리검사 실시가 가 능하다는 점에서도 효과적인 정신건강 서비스임

- 대중문화예술인은 공식적으로 자신의 직업적 정체성에 대해 교육을 받거나 정 립할 기회가 거의 없음. 공공 조직이나 일반 회사는 구성원이 되기 위해 요구되 는 직업윤리 교육 등이 필수인데 반해, 대중문화예술인의 경우는 대중들에게 절 대적인 영향을 끼침에도 불구하고 개인적 경험에 의존하여 직업관을 정립할 수 밖에 없는 구조로 직업적 적응에 어려움이 있음

- 대중문화예술인으로서 자신의 직업적 의미나 정체성을 정립해 보는 교육 프로 그램은 장기적으로 대중문화예술인들이 정신건강의 의미를 직업적 책무나 윤리 와 관련지어 살펴볼 수 있다는 점에서 정신건강의 근원적인 접근임

- 게이트키퍼 교육은 연예인 자살예방을 위한 가장 기초적인 프로그램으로, 정신 건강 교육의 맥락에서 제공될 때 자연스러운 효과가 나타날 수 있으며, 연예인 뿐 아니라 연습생과 매니저, 기획자 대표 및 직원 등 주변을 모두 포함할 때 효 과가 높아질 수 있음

- 교육과 상담은 반드시 대중문화예술인에 대한 이해와 전문성을 갖춘 담당자가 운영하여야 하며, 기본적인 프로그램 뿐 아니라 필요나 요청에 따라 프로젝트 성격의 프로그램을 개발함으로써 이용자의 니즈에 부합하도록 해야 함 
- 콘텐츠 마음건강센터의 중장기 방향

- 대중문화예술인을 위한 자살예방교육이 대중문화계에 정착한 이후에는 중장기 적으로 교육의 내용을 '자살'에 국한하지 않고 대중문화인력 정신건강 전반에 대한 교육으로 확대·발전시켜야 함

- 대중문화예술계의 건전한 발전과 사회적 영향력을 고려하여, 관련 인력의 정신 건강 문제에 보다 적극적으로 임해야 하며, 대중문화예술인 정신건강 정책을 제 도적으로 정착시키기 위한 노력을 기울여야 할 것임

- 정신건강의 문제는 자살문제를 포함한 보다 광범위한 영역을 포괄하며, 대중문 화예술인뿐 아니라 산업계 종사 인력 모두를 대상으로 해야 함

- 따라서 콘텐츠/정신건강관련 기관인 '콘텐츠 마음건강센터'를 독립 기관으로 설 립하여, 대중문화예술산업계 인력의 마음 건강을 도모하고, 콘텐츠로 야기되는 부정적 이용의 문제를 다루며, 더 나아가 콘텐츠의 건강한 이용을 위한 어린이청소년 교육 및 콘텐츠 문화복지 사업을 담당하는 전문기관으로 발전시켜야 함 [그림 5-3] (가칭) ‘콘텐츠 마음건강 센터’ 구성

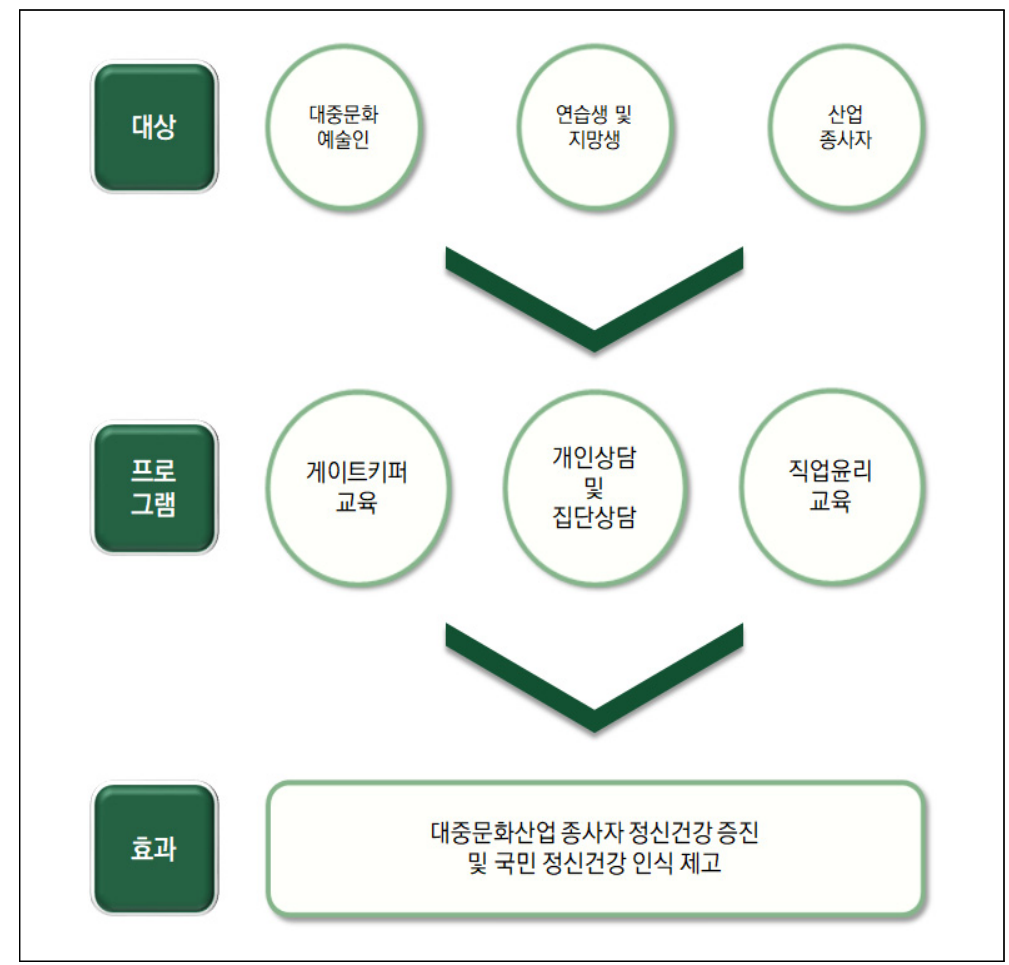





\section{참고문헌}

- 고성은·홍혜영(2009). 중학생의 생활스틑레스가 자살생각에 미치는 영향: 사회적지지 의 매개효과를 중심으로. 청소년학연구 Vol.16 No.11, 97-124.

- 국회예산정책처(2013). 『자살예방정책의 우선순위 및 추진방식 효율화 방안 조사』.

- 김인숙(2009). 연예인 자살보도와 제 3자 효과: 언론의 연예인 자살보도에 대한 태도, 미디어 이용, 미디어 규제와의 관계를 중심으로. 언론과학연구 Vol.9 No.3, 5-36.

- 김정섭(2015). 우리나라 청소년 연기자 보호 제도에 관한 고찰-2014년 시행 '대중문 화예술산업발전법' 분석을 중심으로-. 한국문화콘텐츠학회논문지 Vol. 15 No.1, 86-94.

- 김헌식·양정호(2007). 방송 출연 아동의 권리 보장에 관한 연구: 인권, 노동법적 접근 을 중심으로. 한국정책연구 Vol.7 No.1, 71-93.

- 남기연(2015). 청소년 대중문화예술인의 권리보호를 위한 입법 개선방안 연구 -“대중 문화예술산업발전법”을 중심으로-. 홍익법학 Vol. 16 No.4, 59-85.

- 박진희(2009). 연기자의 스트레스와 우울 및 자살 생각에 관한 연구. 석사학위논문, 연세대학교 행정대학원.

- 백종우·조선진·이수정·옹진영·박종익(2014). 한국형 표준자살예방교육프로그램 [보 고듣고말하기가 게이트키퍼의 개입에 미치는 영향. J Korean Neuropsychiatr Assoc.

• 보건복지부(2020).『2020년 정신건강사업 안내』. 보건복지부.

- 보건복지부·중앙자살예방센터(2020).『2020 자살예방백서』. 보건복지부.

- 보건복지부·중앙자살예방센터·한국기자협회(2018). 『자살보도 권고기준 3.0』. 보건복지부.

- 보건복지부·중앙자살예방센터·한국방송작가협회·생명존중정책 민관협의회 (2019). 『생명존중문화 확산을 위한 영상콘텐츠 자살 방면 가이드라인』. 보건복지부.

- 신미영 외(2010). 유명 연예인 자살보도가 일반인의 자살시도에 미치는 영향. 가정간 호학회지 Vol.17 No.2, 112-119.

- 오지희·김민정(2014). 미디어의 자살보도가 청소년의 자살생각에 미치는 영향: 사회 학습이론을 중심으로. 한국엔터테인먼트산업학회 2014 추계학술대회 논문집. 67-77.

- 이동연(2013). 자살 권하는 사회. 문화과학, Vol. 74, 139-163. 
- 이주연(2014). 연예인의 스트레스와 자살생각 간의 조절효과. 글로벌사회복지연구 Vol.4 No.2, 5-20.

- 이주연·김봉환(2012). 연예인 자살생각의 보호요인-사회적 지지를 중심으로-. 상담학 연구 Vol 13 No.6, 3059-3076.

- 이훈석·전병준(2012). 방송연예인의 감정노동과 직무스트레스가 직무만족도에 미치 는 영향. 한국콘텐츠학회논문지 Vol.12 No.12 616-626.

- 임상원(2009). 자유언론과 인간의 존엄성-대중매체의 '자살'사건 보도에 대한 비판과 대안-. 생명연구 Vol. 13. 12-38.

- 조계화·김영경(2008). 지역사회 네트워크를 이용한 한국노인의 다차원적 자살예방 프 로극램 개발 및 적용. 대한간호학회지, 38(3), 372-382.

- World Health Organization. (2017). Preventing suicide: A resource for media professionals

- 대중문화예술인지원센터: http://www.kocca.kr/cop/contents.do?menuNo= 200987

- 보건복지부 홈페이지: https://www.mohw.go.kr/react/policy/index.jsp?PAR_

- 중앙자살예방센터 홈페이지: http://www.spckorea.or.kr/sub.php?menukey=27)

- 중앙자살예방센터 통계홈페이지: http://spckorea-stat.or.kr/korea01.do

- 한국자살예방협회 홈페이지: http://suicideprevention.or.kr/01_sub/02_sub.html MENU _ID=06\&MENU_ID=06330401\&PAGE=1\&topTitle=)

- 통계청 사망원인통계: https://www.kostat.go.kr/portal/korea/kor_nw/1/6/2/index.board

- 한국예술인복지재단: http://www.kawf.kr/intro/sub02.do

- 동아닷컴 「'연예인 모방자살’ 은 진실」(2012.03.27.)

- BBC News 「The dark side of South Korean pop music」(2011.06.15.)

- Variety Jonghyun Suicide Note Points to Brutal Pressure of Korean Spotlight」(2017.12.19.)

- The Guardian `Kim Jonghyun: SHINee star dies amid an unforgiving K-pop industry」(2017.12.18.) 


\section{ABSTRACT}

\section{A Study on the Policy to Respond to the Suicide Problem of Korean Pop Culture Artists}

Suicide has been a serious problem in South Korea since 2010, ranking $1^{\text {st }}$ or

$2^{\text {nd }}$ in the OECD's major countries' suicide rankings, and topping the list of causes of youth death. In particular, the impact of the suicide of pop culture artists is not limited to the industry, but can be extended to children, teenagers, and overseas fans who like pop culture, and Werther effect may occur which increases the imitative suicide of ordinary people, so more attention is needed. Although Korean pop culture artists have played a major role in enhancing the national image and brand as a key resource for the "Korean Wave", the government and industry have overlooked the fact that their poor working conditions and professional characteristics can easily cause mental health problems, and it is also true that there is a lack of support for them.

Finland in the 1990s and Japan in the early 2000s suffered from the worst suicide rate ahead of us, but they overcame problems with research on suicide prevention, state policy support and active budgeting.

The Korean government has also implemented a full-fledged suicide prevention policy led by the Ministry of Health and Welfare since the mid-2000s when the suicide problem began to get serious. To deal with such problems, Korea Artists Welfare Foundation and the Center for Popular Culture Artists Support have provided programs such as psychological counseling and suicide prevention education. However, the supporting programs have not been successful so far, because the targeted beneficiaries and budgets of the project are very limited. Thus, this research proposes the following policy measures to counter the suicide problem of Korean pop culture artists. 
- Developing suicide prevention programs specialized for Korean pop culture artists

- Developing a separate suicide prevention program that reflects the professional characteristics of Korean pop culture artists

- Establishing a suicide prevention system for Korean pop culture artists

- Promoting the expansion and specialization of the Center for Popular Culture Artists Support

- Expanding budgets related to counseling and mental health programs for pop culture artists

- Raising awareness of suicide prevention education for Korean pop culture artists

- Minister of Culture, Sports and Tourism, presidents of large agencies, heads of related organizations, and celebrities take the initiative to complete suicide prevention education, thereby enhancing social interest in suicide prevention education for pop culture artists in Korea

- Promoting legal mandates for suicide prevention education for Korean pop culture artists

- Revising the law to make suicide prevention education mandatory for those engaged in the pop culture and arts industry in Korea

- Building a mental health center for Korean pop culture artists

- Since suicide of a pop culture artist is the final result of a mental health problem, a systematic response to 'mental health' is required before responding to suicide, and to this end, a separate institution specialized in 'mental health' is required.

- Therefore, as a long-term countermeasure, I propose to build a 'mental center for Korean pop culture artists'.

- The mental health center is responsible for conducting psychological tests and counseling, coaching programs, career path and career ethics education, etc. and linking subjects requiring clinical treatment to specialized institutions, focusing on suicide prevention education for Korean pop culture artists.

\section{Keywords}

Suicide, Pop Culture Artists, Mental Health Center 


\section{집필내역}

연구책임

채지영 한국문화관광연구원 연구위원: 연구총괄, 제1장 제5장

공동연구

윤유경 공군사관학교 교수: 제3장 2절 일부, 제5장 2절 일부

대중문화예술인 자살문제 대응정책 연구

발행인 김대관

발 행 처 한국문화관광연구원

서울시 강서구 금낭화로 154

전화 02-2669-9800 팩스 02-2669-9880

http://www.kcti.re.kr

인 쇄 일 2020년 8월 7일

발 행 일 2020년 8월 7일

인 쇄 인 (사)한국장애인이워크협회 일자리사업장

I S B N 978-89-6035-812-693300

DOI https://doi.org/10.16937/kcti.rep.2020.e3 


\section{A Study on the Policy to Respond to the Suicide Problem of Korean Pop Culture Artists}

\section{口斗安口 \\ .}

17 아래의 $\mathrm{DO}$ 또는 $\mathrm{QR}$ 코드를 통해

$\square$ 이보고서를 무료로 다운로드할 수 있습니다.

https://doi.org/10.16937/kcti.rep.2020.e3
CHAE, JEEYOUNG 